UNIVERSIDADE DE SÃO PAULO

PROGRAMA DE PÓS-GRADUAÇÃO INTERUNIDADES EM ENSINO DE CIÊNCIAS

ANA LUIZA CERQUEIRA DAS NEVES

AS CONTROVÉRSIAS EM TORNO DA EXPERIMENTAÇÃO ANIMAL: CONTRIBUIÇÕES PARA DIVULGAÇÃO CIENTÍFICA POR MEIO DE UMA ANÁLISE DIALÉTICA 


\section{AS CONTROVÉRSIAS EM TORNO DA EXPERIMENTAÇÃO ANIMAL: CONTRIBUIÇÕES PARA DIVULGAÇÃO CIENTÍFICA POR MEIO DE UMA ANÁLISE DIALÉTICA}

Dissertação apresentada ao Programa de PósGraduação Interunidades em Ensino De Ciências para obtenção do título de Mestre em Ensino de Ciências.

Área de Concentração: Ensino de Biologia

Orientadora: Alessandra Fernandes Bizerra 
Autorizo a reprodução e divulgação total ou parcial deste trabalho, por qualquer meio convencional ou eletrônico, para fins de estudo e pesquisa, desde que citada a fonte.

FICHA CATALOGRÁFICA

Preparada pelo Serviço de Biblioteca e Informação do Instituto de Física da Universidade de São Paulo

Neves, Ana Luiza Cerqueira das

As controvérsias em torno da experimentação animal: contribuições para divulgação científica por meio de uma análise dialética. São Paulo, 2016.

Dissertação (Mestrado) - Universidade de São Paulo. Faculdade

de Educação, Instituto de Física, Instituto de Química e Instituto

de Biociências

Orientador: Profa. Dra. Alessandra Fernandes Bizerra

Área de Concentração: Ensino de Biologia

Unitermos: 1. Biologia - Estudo e ensino; 2. Experimentos animais;

3. Divulgação científica; 4. Dialética; 5. Contradição. 
Nome: Neves, Ana Luiza Cerqueira das

Título: As controvérsias em torno da experimentação animal: contribuições para divulgação científica por meio de uma análise dialética

Dissertação apresentada ao Programa de PósGraduação Interunidades em Ensino De Ciências para obtenção do título de Mestre em Ensino de Ciências.

Aprovado em:

Banca Examinadora

Prof Dr

Julgamento:

Prof Dr.

Julgamento:

Prof Dr

Julgamento:
Instituição:

Assinatura:

Instituição:

Assinatura:

Instituição:

Assinatura: 
A Luiz Gonzaga Souza Cerqueira, mestre sala dos nossos corações

(in memoriam) 


\section{AGRADECIMENTOS}

Primeira e inequivocamente a Deus, o principal responsável por mais esta conquista. Pois o Senhor é quem dá sabedoria; de sua boca procedem o conhecimento e o discernimento.

A meus pais, Silvia e José Sabino, minha base, sempre dispostos e prontos para as mais desafiadoras empreitadas. Por cada mensagem de apoio, por todos os momentos juntos.

À minha irmã, Amanda, companheira e confidente. E ao pequeno Vicente, meu sobrinho. Por todos os momentos de felicidade e pelo suporte nas dificuldades.

A toda minha grande, vibrante e calorosa família, que me criou e educou em meio a um reduto de amor, carrinho, alegria e compreensão. Em especial à minha avó, Annitta, pela ternura de cada gesto.

A meu marido, Oscar, por cada centímetro de preocupação e dedicação a que se prestou por este material e por meu bem-estar. Todos os dias. Em cada segundo. Doses inesgotáveis de amor.

À minha orientadora, Alessandra Bezerra, visionária do desafio, parceira na defesa. Por abraçar a causa e acreditar no meu potencial sempre.

Aos amigos Bruno, Camila, Bruna, lara e Marcos, companhias para todas as horas, aliados pra todas as lutas, amores da minha vida.

A todos do grupo de pesquisa CHOICES - cujo nome completo nunca consegui pronunciar. Obrigado pelo apoio de cada um de vocês. 



\section{RESUMO}

NEVES A.L.C. As controvérsias em torno da experimentação animal: contribuições para divulgação científica por meio de uma análise dialética. 2016. 139p. Dissertação (Mestrado). Instituto de Biociências, Universidade de São Paulo, São Paulo, 2016.

O presente trabalho propõe-se a analisar a controvérsia da experimentação animal por meio do método da dialética materialista a partir de duas unidades que compõem a temática: o teor dos argumentos usados por diferentes atores na controvérsia e as contradições que engendram os sistemas de atividade dos sujeitos. Por meio da dialética, buscou-se superar a dualidade dos argumentos apresentados, na busca por novas formas de divulgação científica. Sem julgar a validade e o mérito das argumentações, foram analisados o discurso de duas pesquisadoras, dois ativistas, um político e um representante do Conselho Nacional de Controle de Experimentação Animal. A partir do arcabouço estrutural da Teoria da Atividade, proposto por Engeström, buscamos compreender onde se localizam as contradições mais evidentes no discurso dos sujeitos e discutir como ações de divulgação científica poderiam propiciar um ambiente favorável para a superação dessas contradições e o desenvolvimento qualitativo do sistema de atividade. Por essa razão, queremos trazer, para esta investigação, as conferências de consenso como ferramenta inovadora de comunicação da ciência, em uma abordagem deliberativa e com participação ativa da sociedade, que nos auxilie no avanço desses conflitos.

Palavras Chave: Experimentação Animal, Dialética, Teoria da Atividade, Contradições 


\begin{abstract}
NEVES A.L.C. The controversies surrounding animal experimentation: contributions to scientific dissemination through a dialectical analysis. 2016. 139p. Thesis (Master's Degree). Instituto de Biociências, Universidade de São Paulo, São Paulo, 2016.

This study proposes to analyze the controversy of animal experiments by the method of materialist dialectics from two units that make up the theme: the content of the arguments used by different actors in the controversy and contradictions that engender the activity systems subject. Through the dialectic, he sought to overcome the duality of the arguments made in the search for new forms of science communication. Without judging the validity and the merits of the arguments, we analyzed the speech of two researchers, two activists, a politician and a representative of the National Council for Animal Experimentation Control. From the structural framework of Activity Theory, proposed by Engeström, we try to understand where there are the most obvious contradictions in the discourse of subjects and discuss how science communication actions could provide a favorable environment for overcoming these contradictions and the qualitative development of the system activity. For this reason, we want to bring to this research, consensus conferences as an innovative communication tool of science, in a deliberative approach and active participation of society, to assist in the advancement of these conflicts.
\end{abstract}

Key Words: Animal Experimentation, Dialectic, Activity Theory, Contradictions 


\section{LISTA DE FIGURAS}

FIGURA 1. Algumas notícias sobre experimentação animal dos últimos dois anos 34

FIGURA 2. Modelo da TA da primeira geração 53

FIGURA 3. Modelo da TA da segunda geração - Sistema de Atividade $-54$

FIGURA 4. Modelo da TA da terceira geração $-55$

FIGURA 5. Teste de Wicoxon aplicado às variáveis "sexo" e "testes em animais para salvar vidas humanas" $-73$

FIGURA 6. Teste de Wicoxon aplicado às variáveis "animais de estimação" e "testes em animais para salvar vidas humanas" $-74$

FIGURA 7. Teste de Wicoxon aplicado às variáveis "testes em cães" e "testes em animais para salvar vidas humanas" $-75$

FIGURA 8. Teste de Wicoxon aplicado às variáveis "testes em moscas" e "testes em animais para salvar vidas humanas" $-75$

FIGURA 9. Sistema de Atividade da pesquisa com animais $-88$

FIGURA 10. Sistema de atividade de proteção animal $-92$

FIGURA 11. Sistema de atividade de regulação da experimentação animal ------99

FIGURA 12. Rede de Sistemas de atividade da questão da experimentação animal 


\section{LISTA DE QUADROS}

QUADRO 1. Principais regulamentações que estabelecem medidas de proteção aos animais no Brasil 30

QUADRO 2. Objetivos e questões da pesquisa $-59$

QUADRO 3. Perfil do público respondente $-61$

QUADRO 4. Natureza dos Argumentos - Pesquisadores $-79$

QUADRO 5. Natureza dos Argumentos - Membros SPA $-82$

QUADRO 6. Natureza dos Argumentos - Político $-83$

QUADRO 7. Natureza dos argumentos - Membro do Concea $-85$

QUADRO 8. Contradições mais evidentes dentro dos sistemas de atividade ---111

QUADRO 9. Contradições mais evidentes entre a atividade de pesquisa e atividade de proteção animal 111

QUADRO 10. Contradições mais evidentes entre a atividade de proteção animal e a atividade de regulação da experimentação animal 112 


\section{LISTA DE SIGLAS}

3R's Replacement, Reduction and Refinement (Substituição, Redução e Refinamento)

\begin{tabular}{|c|c|}
\hline C\&T & Ciência e Tecnologia \\
\hline$C C T$ & Comissão de Ciência, Tecnologia, Inovação, Comunicação e Informática \\
\hline Ceua & Comissões de Ética no Uso de Animais \\
\hline Concea & Conselho Nacional de Controle de Experimentação Animal \\
\hline CSC & Controvérsias Sociocientíficas \\
\hline CTS & Ciência, Tecnologia e Sociedade \\
\hline EB & Eurobarometer \\
\hline ICTQ & Instituto de Ciência, Tecnologia e Qualidade \\
\hline ISSP & International Social Survey Program \\
\hline $\mathrm{MCTI}$ & Ministério da Ciência Tecnologia e Inovação \\
\hline NSF & National Science Foundation \\
\hline OGM & Organismos Geneticamente Modificados \\
\hline ONGs & Organizações Não Governamentais \\
\hline PCNs & Parâmetros Curriculares Nacionais \\
\hline $\mathrm{PL}$ & Projeto de Lei \\
\hline PLC & Projeto de Lei da Câmara \\
\hline TA & Teoria da Atividade \\
\hline
\end{tabular}




\section{SUMÁRIO}

\section{APRESENTAÇÃO}

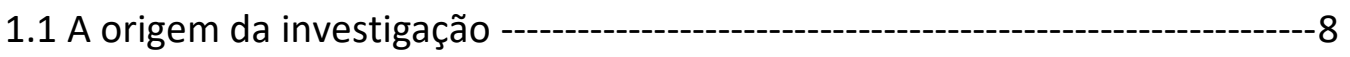

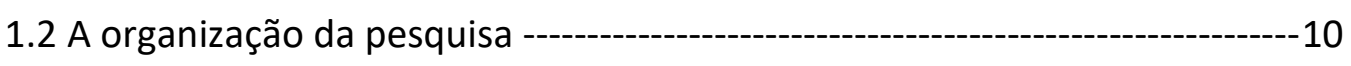

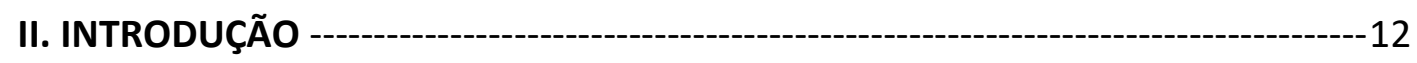

2.1 Importância da análise de controvérsias para a educação científica --------14

2.2 Controvérsias sociocientíficas no âmbito da educação formal ---------------16

2.3 As controvérsias no âmbito da educação não formal e divulgação das ciências

2.4 Experimentação Animal: início e vida de uma controvérsia -------------------24

2.4.1 Experimentação Animal no Brasil: principais desdobramentos -------26

2.4.2 Experimentação Animal e sociedade: a percepção pública ------------34

III. REFERENCIAL TEÓRICO

3.1 Dialética: origem e fundamentos 41

3.1.1 O materialismo dialético de Marx

3.20 método dialético 45

3.3 A dialética em Vigotski e o conceito de atividade $-48$

3.4 A Teoria da Atividade $-50$

IV. OBJETIVOS DA PESQUISA $-58$

V. METODOLOGIA DA PESQUISA $-60$

5.1 Caracterização da pesquisa ---------------------------------------------------------------60

5.2 Participantes da pesquisa ------------------------------------------------------------61

5.3 Instrumentos e procedimentos de coleta e geração de dados ---------------63

5.4 Procedimentos de extração, seleção e análise dos dados ---------------------66

5.4.1 A dialética como método de superação da dualidade na questão da experimentação animal 
VI. AS CONTRADIÇÕES NA CONTROVÉRSIA DA EXPERIMENTAÇÃO ANIMAL:

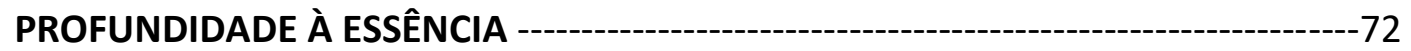

6.1 Questionário de percepção pública acerca da Experimentação Animal ----72

6.2 A natureza dos argumentos na controvérsia da Experimentação Animal$-77$

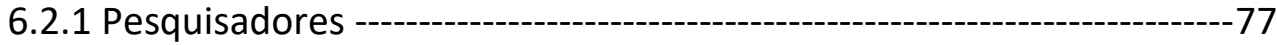

6.2.2 Membros de sociedades de proteção animal --------------------------79

6.2.3 Político $-82$

6.2.4 Membro do Conselho nacional de Controle de Experimentação Animal 83

6.3 A experimentação animal nas diferentes atividades sistêmicas $-86$

6.3.1 A atividade de pesquisa com animais $-87$

6.3.2 A atividade de proteção animal $-91$

6.3.3 A atividade de regulação da experimentação animal $-98$

6.3.4 A rede de sistemas de atividade que compõem a questão da experimentação animal 101

VII. NOVOS CAMINHOS DE PESQUISA E PRÁTICAS $-103$

6.1 As conferências de consenso como alternativa para superação das contradições$-106$

6.2 Os surveys como instrumentos de divulgação científica $-108$ 



\section{APRESENTAÇÃO}

\subsection{A Origem da Investigação}

A licenciatura sempre esteve presente em meu caminho, mesmo nas coisas simples, em diversas circunstâncias. As brincadeiras de "escolinha" já davam indícios do que eu gostaria de fazer o resto da vida. Ciências sempre foi minha disciplina favorita na escola. Porque era colorido, porque eu podia colocar a mão, podia estudar em qualquer lugar, na minha casa, na rua, na praça. Eu podia observar as plantas, a água, os bichos, e podia fazer perguntas. E eu fazia. Muitas. Por isso minha escolha profissional aconteceu precocemente. Quando eu tinha oito anos me decidi, seria tia de Ciências. E nunca quis ser outra coisa na vida.

Quando entrei na graduação era uma das únicas pessoas a querer, de forma convicta, ser professora. Por isso enquanto todos desejavam estágios na área de pesquisa nos mais diversos laboratórios da Rural, fiz estágio na Sala de Ciências (SESC - Rio), um espaço fascinante, quase mágico, totalmente diferente dos outros centros de Ciências do Rio de Janeiro, com uma proposta totalmente inovadora. Foi por causa da Sala de Ciências e sua Mulher Pássaro que resolvi percorrer os caminhos da educação não formal e da divulgação científica. Meu fascínio pelas discussões e potencialidades da área está materializado nos trabalhos que venho desenvolvido desde então.

Durante esses três anos e meio de mestrado, meu projeto inicial foi construído e, por vezes, reconstruído, frente às novas experiências vivenciadas em disciplinas, eventos e no grupo de pesquisa do qual faço parte. O projeto inicial, elaborado já no primeiro semestre do presente curso de mestrado visava investigar, sob a luz da Perspectiva Histórico-Cultural e da Teoria da Atividade, o processo de ensino em museus de ciências, a partir de questionamentos como: é possível considerar os Museus ambientes de Ensino? As ferramentas mediadoras e os recursos educativos dos Museus são suficientes para promover a apropriação de conhecimentos teóricos e a aprendizagem?

No entanto, ao aprofundarmos tais discussões, novos rumos tornaram-se visíveis. Acreditamos que a investigação sobre o papel dos museus de ciências no ensino é relevante para a área. Todavia, estudar um único museu não nos garantiria subsídios necessários para 
possíveis generalizações ou uma reflexão mais profunda. Tal pesquisa precisaria de muito mais tempo, para que contemplássemos diversas instituições, o que não é realizável em um curso de mestrado.

Dessa forma, em discussões com a orientadora e o grupo de pesquisa, foram surgindo novos temas relevantes que carecem ainda de investigações, dentro da temática museal, no âmbito do Ensino de Ciências. Surgiu então a necessidade de investigar o papel dos museus de ciências na abordagem de temas controversos, como a experimentação animal.

Nosso objetivo, então, tornou-se identificar as concepções que os públicos de museus de ciências possuem sobre a temática da experimentação animal e analisar as interações que podem ocorrer durante sua participação em ações educativas com esse tema. O estudo visava ainda mapear, sob a ótica da Teoria da Atividade, os movimentos das contradições em jogo na construção das concepções do público ao se deparar com ações educativas voltadas para reflexões sobre essa.

Entretanto, por questões internas à instituição museal escolhida para essa investigação (o Museu Biológico do Instituto Butantan), não foi possível desenvolver e aplicar uma ação educativa sobre experimentação animal. Além disso, o possível fechamento do museu para reformas no ano passado prejudicaria consideravelmente nossa coleta de dados.

A fim de "driblar" esses imprevistos, e a partir de discussões em eventos da área, pensamos então em propor e fornecer subsídios para a elaboração de ações de divulgação científica como estratégia de avanço nos conflitos que permeiam a temática da experimentação animal e analisar, sob a perspectiva histórico-cultural e da Teoria da Atividade, como essas tensões e conflitos são superados (ou não) pelos sujeitos envolvidos dentro das atividades que envolvem a pesquisa em animais. 


\subsection{Organização da Pesquisa}

Esta dissertação está organizada de modo a permitir que o leitor percorra o mesmo caminho que seguimos em nossos estudos. Logo após esta apresentação, a primeira seção introdutória aponta e discute algumas pesquisas relacionadas às controvérsias sóciocientíficas e suas relações, principalmente, com o Ensino de Ciências no âmbito formal e não formal. Além disso, delimitamos o que para esta pesquisa está sendo considerado como controvérsias sociocientíficas, já que sua própria definição é controversa na literatura.

Nesta pesquisa, nosso foco está voltado para uma controvérsia específica e atual, o uso de animais em pesquisa, ou experimentação animal. A seção 3 da introdução aborda os diferentes pontos que causam as controvérsias inerentes a esta questão e como ela vem sendo discutida no Brasil, os principais desdobramentos dessas discussões, especialmente no que diz respeito à legislação brasileira. Levantaremos também os resultados de algumas pesquisas de opinião pública acerca desta temática em diversos países, inclusive o Brasil, enfatizando como esses dados estão sendo utilizados por pesquisadores, principalmente europeus, para um aprofundamento nos debates que envolvem a experimentação animal.

O capítulo 3 traz discussões sobre o embasamento teórico desta investigação. Enfatizaremos o método dialético materialista como forma de interpretação do nosso fenômeno. Buscamos com ele nos aproximar um pouco mais da essência da questão, analisando suas unidades, relações e contradições. Com raízes no materialismo históricodialético, a Teoria da Atividade nos auxilia a compreender como as tensões estão estruturadas nos sistemas de atividade dos sujeitos envolvidos na controvérsia e como elas são superadas (ou não).

Nossos objetivos e respectivas questões de pesquisa estão compilados no capítulo 3 , seguidos dos caminhos metodológicos que percorremos para desenvolver este trabalho, nossos sujeitos de pesquisa e ferramentas de análise de dados, explícitos no capítulo 5.

Os resultados da nossa análise são apresentando no capítulo 6. Buscamos compreender como os argumentos dos sujeitos estão enraizados em sistemas de valores, a partir de categorias pautadas na Teoria da Moral. Além disso, o arcabouço estrutural da 
Teoria da Atividade nos permitiu localizar as contradições dentro e entre os sistemas de atividades dos sujeitos envolvidos na questão. A partir desses resultados, propomos, no capítulo 7, estratégias de divulgação científica que propiciem um ambiente favorável para a superação das contradições e um avanço qualitativo na questão. 


\section{INTRODUÇÃO}

É indiscutível a importância das ciências e da tecnologia no mundo atual, bem como sua influência nos processos de transformações políticas das sociedades contemporâneas. Por isso, o conhecimento das ciências pela população é um objetivo de muitos países, expresso por meio de seus currículos (FENSHMAN, 1997) e de numerosas iniciativas, como a revitalização de museus, o alargamento do espaço destinado à ciência nos meios de comunicação social e a organização de grandes exposições e feiras (QUEIROZ, 1998). O protagonismo da ciência na sociedade contemporânea tem então um efeito implícito: os temas científicos se transformam, como nunca, em questões de ciência, tecnologia e sociedade, representadas no movimento de mesmo nome - CTS (VOGT; POLINO, 2003).

Algumas dessas questões que nascem no âmbito científico e/ou tecnológico, quando encaradas pelo restante da sociedade, provocam tensões, polêmicas e debates, que podem ser consideradas Controvérsias Sociocientíficas (CSC). De acordo com Meadel (2015), controvérsias são estruturas tríades estabelecidas pelas diferenças entre duas partes que se reconhecem como legítimas por atribuírem valor aos seus argumentos diante de um púbico, que compõe a terceira parte. Para a autora, a maior dificuldade está em definir que temas científicos são controversos na sociedade.

Não estamos nos referindo neste estudo às controvérsias científicas, isto é, às disputas conduzidas publicamente sobre um assunto de opinião considerado significativo por um número de cientistas (NARASIMHAN, 2001), reconhecidas pela discordância dentro da comunidade de pares. Referimo-nos às questões sociocientíficas que suscitam necessariamente "nos diferentes atores sociais envolvidos, posicionamentos políticos, sensibilidades éticas e estéticas diversificadas ou diferentes maneiras de interpretar uma dada realidade" (SILVA; CARVALHO, 2007, p. 5) e, por isso, possuem natureza controversa.

Partimos do pressuposto de que nem toda questão que se entrelaça em dimensões sociais e científicas é controvertida publicamente. Para esta investigação, nos interessam os temas que nascem e pertencem à ciência e/ou tecnologia refletidos pelo restante da sociedade, que geram discussões e que afetam opiniões e a tomada de decisão dos cidadãos. Ou seja, só se tornam controversos quando, extrapolando o âmbito científico, são questionados de alguma forma pela população. 
As potencialidades das controvérsias para a educação em ciências têm sido foco de numerosas investigações ao longo das últimas décadas. Segundo Gago (1990), as CSC formam uma ponte entre a cultura científica, partilhada pela comunidade científica, e a educação científica, alargada a toda população. Possuem, dessa forma, um enorme potencial para discussões, especialmente no Ensino de Ciências.

Quando abordadas em sala de aula, as controvérsias exercem papel fundamental no que se refere à construção de uma visão de ciência como empreendimento e processo social, dotada de valores e elementos controversos. Ao mesmo tempo, essas discussões, ao contemplar conteúdos mais próximos à realidade dos alunos, poderiam aumentar seu nível de envolvimento em processos de avaliação de outras questões sociocientíficas atuais, fazendo-os participar ativamente como cidadãos responsáveis.

É necessário, entretanto, que as CSC não sejam exploradas apenas no âmbito escolar do Ensino de Ciências, através de seus currículos, mas desenvolvidas também por meio de ações de comunicação científica que visem a educação em seu sentido mais amplo: a formação de cidadãos capazes de exercer com responsabilidade seu papel social (SANTOS; MORTIMER, 2001). Em uma sociedade democrática, é imprescindível que as decisões sobre as questões científicas e tecnológicas extrapolem a comunidade científica. Para tanto, a população deve estar preparada para acompanhar, avaliar e controlar o progresso científico, suas implicações e controvérsias.

Para este estudo, destacamos a Experimentação Animal como controvérsia sociocientífica atual. Embora a prática em si se mantenha exclusiva à comunidade científica, as questões inerentes a ela extrapolam os limites da ciência, principalmente no que se refere aos aspectos morais que envolvem o direito do homem sobre os animais. $\mathrm{O}$ uso de animais em pesquisas vem sendo, então, amplamente discutido nos últimos anos em inúmeros ambientes e por diversos membros da sociedade.

No Brasil, essas discussões contribuíram para o avanço da questão no que diz respeito à legislação, embora ainda pouco consolidada e específica, e na obrigatoriedade de aprovação das comissões de ética para a realização de pesquisas com animais. Contudo, o embate "contra versus a favor" ainda se perpetua e não há uma participação direta e efetiva da sociedade na avaliação dessa controvérsia juntamente com os cientistas e outros 
sujeitos envolvidos na questão. Fica a cargo da mídia o papel de principal formador da opinião pública, incitando a população na escolha de um dos lados.

Faz-se necessário, portanto, o desenvolvimento de ações, sobretudo no campo da divulgação científica, que promovam uma participação pública mais efetiva nos assuntos que permeiam a ciência e tecnologia, neste caso, a experimentação animal. Para que essas ações sejam desenvolvidas e implementadas de maneira satisfatória é preciso ir ainda mais além e analisar esses assuntos controversos de uma forma mais profunda, superando sua dualidade e compreendendo as relações, limites e tensões inerentes à questão.

\subsection{Importância da análise de controvérsias para a educação científica}

A compreensão da ciência como empreendimento social, construída a partir da ação de sujeitos em seus contextos, tem sido objetivo da educação científica expressa tanto nos currículos de Ensino de Ciências, sobretudo aqueles entrelaçados ao movimento CTS, quanto em iniciativas de comunicação da ciência. Tendo a alfabetização científica como um dos seus principais argumentos, a educação em ciências não se limita apenas à apropriação dos conteúdos científicos, mas contempla o desenvolvimento de capacidades, valores e atitudes que envolvem também questões éticas (GILBERT, 2000).

Algumas pesquisas apontam que, nos últimos anos, a justificativa relacionada à construção de uma sociedade mais democrática tem sido bastante utilizada nos documentos que determinam ações para a educação em ciências no Brasil, sobretudo no âmbito escolar, por meio dos PCNs (MOURA, 2012).

O conhecimento sobre como a natureza se comporta e a vida se processa contribui para o aluno se posicionar com fundamentos acerca de questões bastante polêmicas e orientar suas ações de forma mais consciente. [...] A criança não é cidadã do futuro, mas já é cidadã hoje, e, nesse sentido, conhecer ciência é ampliar a sua possibilidade presente de participação social e viabilizar sua capacidade plena de participação social no futuro. (PCN, Volume 4, p.22) 
A partir dessa conjuntura ampliou-se a discussão sobre a dimensão cidadã da educação científica que prevê a participação protagonista do indivíduo nas decisões sobre as opções científicas e tecnológicas, deixando assim de ser entendidas como responsabilidade exclusiva de especialistas e representantes do governo. Para Moura (2012), o termo cidadania científica é mais apropriado quando nos referimos ao protagonismo do cidadão nas questões sociocientíficas. De acordo com a autora, a cidadania científica visa:

[...] incorporar à educação científica o direito de acesso à informação e às controvérsias produzidas pelos autores sociais no âmbito dos processos criativos científicos e de seus desdobramentos éticos, políticos e mercantis, como dimensões fundamentais aos processos de democratização da ciência. (MOURA, 2012, p.21).

Surge assim mais um argumento favorável à educação científica, pela qual o indivíduo capacita-se a responder e atuar ativamente frente às controvérsias (KOLSTOE, 2001). Em uma sociedade democrática, é essencial que os indivíduos estejam aptos a mergulhar no cerne de uma controvérsia, reconhecendo suas causas, construindo opiniões embasadas e participando de processos de tomada de decisão (ibdem).

De acordo com Meadel (2015), as controvérsias são indicativos das formas de organização do debate público em uma democracia. Sua análise é uma ferramenta heurística valiosa: nos revela padrões de racionalidade dos atores envolvidos, permitindonos compreender como esses modos de racionalidade se enfrentam em sua dimensão mais sensível - baseada nas experiências e discurso dos membros que integram uma controvérsia.

Ao mesmo tempo, mergulhar em uma controvérsia nos mostra o quanto é difícil construir um debate público que reflita a diversidade e a complexidade do mundo em que vivemos. Por isso é essencial que, em uma análise, grande parte dos sujeitos envolvidos em uma controvérsia sejam considerados. Um debate bem-sucedido precisa da expressão dos atores envolvidos nas mesmas condições, com igualdade de representação dos seus pontos de vista. E este é o ponto crucial da dificuldade em representar as CSC no espaço público. Geralmente essa representação é tendenciosa e não permite a construção de discussões mais ricas, como veremos mais adiante. 
Um ponto importante na questão é que considerar os diferentes pontos de vista não é o mesmo que dizer que todos os membros integrantes de uma controvérsia possuem a mesma voz. Segundo Meadel (2015), quando analisamos uma controvérsia criamos uma simetria artificial dos argumentos. Isto é, eles são colocados em um mesmo nível para torná-los visíveis, para construir entre eles uma equivalência. Contudo, quando colocamos atores de uma controvérsia no mesmo nível, para estudar seus discursos, interesses e estratégias, não podemos esquecer que nem todos possuem os mesmos recursos para aplicá-los no espaço público, nem todos são iguais perante o jornalista que divulga ou a política que decide. Existem relações de poder inerentes à questão que são essenciais, que devem ser consideradas e reveladas, para o fomento de um debate satisfatório.

Assim, entendemos que, apesar dos numerosos desafios, as controvérsias sociocientíficas possuem potencialidades fundamentais para o desenvolvimento do pensamento crítico e independência intelectual no que se refere à apropriação da ciência como cultura indispensável à formação cidadã.

\subsection{Controvérsias sociocientíficas no âmbito da educação formal}

Em uma sociedade democrática, a avaliação pública da ciência requer a participação e o envolvimento do maior número possível de cidadãos na tomada de decisões referentes às questões sociocientíficas como um todo, o que só é possível através de uma compreensão do que é a ciência e de como é produzida.

Contudo, são os meios de comunicação social a fonte de informação científica de mais fácil acesso para o público em geral, o que reforça a necessidade da escola, em especial do Ensino de Ciências, de promover discussões em torno das controvérsias sociocientíficas.

O uso das CSC no ensino de ciências, dentro do contexto escolar, tem sido investigado por diversos autores (BARBOSA; LIMA, 2009; NASCIMENTO; ALVETTI, 2006; REIS, 2004; ROBOTTOM, 2011; SIMONNEAUX, 2011; ZUIM; FREITAS, 2007) e as suas potencialidades vêm sendo ressaltadas, principalmente no que se refere ao desenvolvimento do pensamento crítico e da independência intelectual (RUDDUCK, 1986); 
bem como ao desenvolvimento cognitivo, social, político moral e ético dos alunos (REIS; PEREIRA, 1998; ZEIDELER; LEWUS, 2001). Entretanto, para o desenvolvimento dessas capacidades, é necessário que os alunos sejam envolvidos de forma participativa nesses temas controversos, o que nem sempre é possível na realidade escolar.

De uma forma geral, o Ensino de Ciências, em seu currículo escolar, não explora de maneira suficiente as potencialidades das controvérsias. Alguns estudos apontam que a principal dificuldade em se trabalhar com as CSC em sala de aula é que, geralmente, esses tipos de problemas são pouco delimitados, multidisciplinares, heurísticos, carregados de valores (éticos, ecológicos, morais, educacionais, culturais e religiosos) e afetados pela ausência de um conhecimento específico (REIS, 2004; REIS; PEREIRA, 1998).

É notório que as CSC têm um impacto importante nas concepções de ciência dos professores e alunos. No entanto, as discussões são pouco frequentes em sala de aula, mesmo com o reconhecimento da relevância do tema pelos professores ou a integração da questão nas orientações curriculares. No geral, os professores evitam ou têm receio de abordar o tema em sala. Reis e Galvão (2008) apontam três motivos principais: a) medo da falta de controle durante as discussões; b) falta dos conhecimentos necessários à discussão das CSC como natureza da ciência, aspectos sociológicos, políticos e éticos dos assuntos em causa; c) falta de tempo devido ao excesso de conteúdo nos currículos de ciências. A ocorrência dessas discussões no ambiente escolar depende, então, da convicção dos professores na relevância educacional dessas atividades.

Além dos motivos citados acima, a falta de material de formação também é apontada pelos professores como uma barreira para o fomento de discussões sobre as CSC em sala (OLIVEIRA; REZLER, 2006). O principal material utilizado pelo docente em sala de aula ainda é o livro didático. No geral, os livros de Ciências e Biologia abordam alguns conteúdos contemporâneos (principalmente os relacionados à genética: biotecnologia, organismos transgênicos, clonagem) sob a forma de textos ilustrativos presentes em seções, apêndices ou quadros no decorrer dos capítulos (MARTINS; DAMASCENO, 2002). Contudo, esses conteúdos tendem a apenas fornecer informações, como avanços científicos/tecnológicos e seus benefícios para a sociedade, sem destacar as questões controversas ou promover alguma discussão. 
Nascimento e Alvetti (2006) apontam que os profissionais que conseguem, mesmo de forma superficial, introduzir as CSC em suas aulas utilizam principalmente publicações de divulgação científica ou reportagens da mídia para promover atividades em torno das controvérsias, pois, dessa maneira, os temas ficam mais próximos ao cotidiano dos alunos.

Frente todas essas dificuldades enfrentadas pelo professor, faz-se necessário o aumento dos esforços para o desenvolvimento de estratégias que contribuam para a introdução de discussões sobre as controvérsias sociocientíficas no ambiente escolar. Dado que as CSC são questões que permeiam diversas áreas do conhecimento, os docentes devem estar aptos a abordá-las em sua prática com segurança.

Martínez Pérez e Carvalho (2009) - em estudo desenvolvido com professores de Ciências (química e biologia) da Educação Básica que cursavam uma disciplina de pósgraduação relacionada às questões sociocientíficas - afirmam que os docentes julgam ser extremamente necessário o oferecimento de cursos de formação continuada que abordem essas questões, já que as notícias oriundas da mídia e os materiais disponíveis não proporcionam o embasamento necessário ao fomento das discussões das CSC em sala de aula.

Torna-se relevante, então, o papel das instituições de ensino superior. Não só em desenvolver, durante a formação inicial nas licenciaturas, atividades que proporcionem aos futuros docentes subsídios para abordagem de controvérsias sociocientíficas nas aulas de ciências, mas também promover cursos de formação para os profissionais que já atuam no Ensino de Ciências. Além disso, é importante que as universidades em todas as suas esferas - pesquisa, ensino e extensão - contribuam para que, a partir das discussões em torno das CSC, haja maior envolvimento e engajamento dos cidadãos nas questões relacionadas à ciência e tecnologia.

Além disso, como a promoção da educação científica não é restrita ao Ensino de Ciências somente em seu âmbito formal, é necessário que as discussões sobre CSC não estejam a cargo somente da escola, mas haja ampla integração e mobilização dos setores políticos, sociais e da comunidade científica através de fóruns de debates, assembleias e ações de divulgação científica que permitam maior participação da sociedade na tomada de decisão no que se refere aos assuntos de CTS. 


\subsection{As Controvérsias no âmbito da educação não formal e da divulgação das ciências}

A comunicação é um dos aspectos fundamentais de uma controvérsia. É a característica necessária para que o debate público aconteça. E são os museus, mais precisamente os de ciências, as instituições que possuem reconhecidamente o papel de divulgar a Ciência, suas implicações na sociedade e suas controvérsias.

Entretanto, frente à diversidade de questões, podemos considerar que as ações museais nesse campo ainda são bastante tímidas, especialmente no Brasil. De acordo com Nelkin (1995), nas últimas décadas, as controvérsias sociocientíficas têm sido abundantes, envolvendo cientistas, políticos, empresários, movimentos sociais e outros setores da sociedade. Elas permeiam diferentes áreas da vida dos cidadãos, como questões ambientais e econômicas, impactos industriais, propriedade intelectual ou saúde. Mas, ao olharmos para os museus, notamos que poucas exposições e ações educativas estão centradas nessas questões.

No geral, pesquisas que buscam investigar temas controversos no âmbito da educação não-formal e da divulgação científica têm se centrado em três questões principais: 1) compreender por que museus e centros de ciências evitam temáticas controversas, 2) analisar a forma como exposições retratam os temas controversos (análise do discurso expositivo) e 3) investigar formas de interação entre exposições controversas e públicos (MARANDINO et. al, 2016).

Trabalhos como o de Butler (1992), Macdonald (2002 e 2004), Ward (1997), Levidow (1998), por exemplo, tentam responder à primeira questão apontando que o financiamento das exposições pode gerar tensões a serem evitadas pelos espaços museais. Considerando que o conteúdo exibido deve estar de acordo com a posição e os interesses de quem financia, os museus podem ser cerceados ideologicamente.

Uma outra ponderação sobre a falta de ações museais nessa perspectiva possui caráter epistemológico. Como citado anteriormente, para Reis (2004) e Reis e Pereira (1998) esses tipos de questões são pouco delimitadas, multidisciplinares, heurísticas, carregadas de valores e afetadas pela ausência de um conhecimento específico. Segundo 
os autores, essas características atribuem alto grau de dificuldade para a elaboração de ações envolvendo questões sociocientíficas.

O caráter axiológico também aparece nestas investigações. Delicado (2009), pautada nas ideias de Nelkin (1995), Gregory e Miller (1998) e Wynne (2002), reforça, ao estudar museus de ciências portugueses, que as controvérsias são vistas como potencializadoras da desconfiança do público em relação às ciências, já que a percepção de que os cientistas nem sempre concordam entre si pode gerar dúvidas a respeito da ciência enquanto sinônimo de "verdade", de que as metodologias de pesquisa são sempre objetivas e precisas e de que as interpretações científicas são neutras e apolíticas.

MacDonald (2002) ressalta ainda outros desafios. Para a autora, informações e eventos mudam rapidamente, possibilitando que as exposições se mostrem "desatualizadas" quando abertas ao público. Em outro trabalho publicado com Silvertone (1992), enfatiza também a ameaça que esse tipo de tema causa ao modelo dominante de comunicação pública da ciência, pelo qual cientistas "transmitem" seus dados a um público "meramente receptivo".

Em relação aos discursos expositivos que retratam temas controversos, Girault e Molinatti (2015) afirmam que os museus, na última década, estão propensos a um movimento de confinamento/contenção a abertura/divulgação. Os autores, após analisarem uma série de exposições com temáticas controversas na Europa, Estados Unidos e Canadá, retratam que é possível localizar essas exposições sobre um contínuo onde, em um extremo temos o confinamento e a retenção das informações, ocultação e o uso excessivo de eufemismos; e no outro um discurso expositivo rico em provocações, denúncia pública e críticas, fomentador do debate público. Este movimento ainda lento das instituições museais na direção de exposições mais 'abertas e divulgadoras' pode ser percebido ao observamos algumas pesquisas sobre o tema.

MacDonald e Silvertone (1992) analisaram a exposição "Alimento para o pensamento", aberta ao público do Science Museum (Londres), em 1989, focando na controvérsia 'intoxicação alimentar'. As autoras comparam como a temática é retratada nas grandes mídias e na própria exposição, e apontam para o fato da controvérsia estar 
mais evidente nos meios de comunicação do que no discurso expositivo, no qual foi apresentada apenas como pano de fundo da representação.

Bourdia (2003), após investigar vinte exposições sobre energia nuclear na Europa, concluiu que o modelo de déficit, aquele no qual a informação flui de forma unilateral - da ciência para o público considerado leigo - é a postura dominante de tratamento das controvérsias entre ciência e sociedade em museus e centros de ciências. Em todos os casos, afirma a autora, a atuação da instituição era externa ao debate. Apenas eram criadas condições para o benefício público.

Pesquisas realizadas sobre o discurso expositivo em exposições de temáticas ambientais, tais como o de biodiversidade (QUERTIER; GIRAULT, 2011), ou questões de saúde como a neurociência (MOLINATTI; GIRAULT, 2007), concluíram que as instituições museais tendem a confinar as controvérsias ciência/sociedade no limite de suas dimensões científicas. Deixam assim de colocar em cena os atores das controvérsias e seus argumentos, retratar outros pontos de vista, e limitam-se à transmissão de saberes científicos que são considerados necessários a apreensão dos termos no debate social.

Delicado (2009), ao analisar uma exposição sobre manipulação genética de alimentos em Portugal, obteve resultados semelhantes. A autora afirma que a controvérsia foi retratada tendenciosamente, o que provavelmente se relaciona ao financiamento da exposição feito por uma empresa do ramo alimentício. Apontou ainda que o papel da ciência apresentada no discurso expositivo é sempre utilizado para legitimar e apoiar os argumentos sobre organismos geneticamente modificados (OGM).

Segundo a autora, embora alguns dispositivos expográficos tenham introduzido algumas provocações sobre questões éticas referentes à biotecnologia e exploração do solo, estes foram pontuais e não possibilitaram discussão com o público. O lado negativo da manipulação genética de alimentos, os riscos dos OGM e controvérsia nas ciências relacionadas aos seus efeitos na saúde humana não foram citados na exposição. Também não foi observada a abordagem de questões ambientais e conflitos entre as ciências, ambientalistas e empresas multinacionais. 
Delicado conclui que a exposição apenas reforçou, mais uma vez, a comunicação científica pautada no modelo de déficit. $O$ fato pode ser atribuído à majoritária composição da equipe museal por especialistas das "áreas duras", que podem possuir pouca consciência social e estão muitas vezes alheios às discussões no campo da compreensão pública da ciência.

No Brasil, o foco, nestes raros estudos, dá-se, prioritariamente, nesse eixo de pesquisa (análise do discurso expositivo), apontando o seu papel na mudança de paradigma sobre a participação do público em assuntos de ciência e tecnologia (como em CONTIER; MARANDINO; NAVAS, 2007). Nesta investigação, as pesquisadoras analisaram exposições controversas em três museus: uma exposição sobre biotecnologia no Espaço Biodescoberta - Museu da Vida; a exposição 'Energia Brasil', no Museu de Astronomia e Ciências Afins; e a área expositiva 'Alimentos Transgênicos' no Museu Universum - México.

As autoras destacam as dificuldades das instituições em tratarem temas controversos e como isso se reflete no discurso expositivo. A maior parte do discurso analisado não focava na controvérsia explicitamente e, os temas, na maior parte das vezes, não traziam questões fundamentais para um debate público satisfatório.

Pesquisas mais recentes, entretanto, são mais animadoras no sentido de apresentar exposições e ações museais que trabalham com temáticas controversas de forma mais crítica, propiciando uma discussão mais ampla com o público. Girault e Molinatti (2015) apresentam inovações museológicas que se destinam à participação do público em debates sociais. Um exemplo é o do Aquário de Monterey (Canadá), em que visitantes podem registrar suas opiniões a respeito de controvérsias exibidas na televisão que abordam a conservação dos oceanos.

Os autores analisaram ainda a exposição 'Question of Truth', proposta em 2006 no Centro de Ciências de Ontário (Toronto), e a consideram um exemplo de como instituições museais podem abordar uma temática ciência/sociedade. De acordo com os pesquisadores, a exposição assume claramente uma abordagem crítica à controvérsia. 0 objetivo declarado é questionar a verdade por meio dos diferentes pontos de vista para mostrar como essas diferentes crenças podem ser parte de uma abordagem científica. A narrativa da exposição é estruturada por perguntas como: 'Foi a ciência?'; 'Foi justo?'; 
'Podemos medir o valor de um ser humano?'; 'Quem é superior, moral e inteligente?'; incentivando o visitante a questionar a premissa de neutralidade da Ciência (ibden).

Essa postura crítica das instituições museais para tratar temas relacionados à ciência em sociedade se desenvolve com a passagem de um modelo comunicativo de Compreensão Pública da Ciência para um modelo de engajamento do público na ciência (HAGENDIJK; IRWIN, 2006). Da mesma forma, iniciativas como o New Metropolis Forum, de Amsterdã, o Museu de Ciência de Boston, o College of the City of Science and Industry, em Paris, a caixa de Ciência ou "Welcome Wing" do Museu da Ciência, em Londres (Delicado, 2009), fazem parte desta ruptura no modelo de déficit.

Em relação à linha de pesquisa que investiga as formas de interação, Meisner e colaboradores (2007) destacam que, apesar do baixo número de pesquisas que focam nas interações e nas formas de promover o engajamento dos visitantes, há um crescimento no interesse, por parte dos museus, na elaboração de exposições que promovam maior participação do público com questões sociocientíficas, por meio de recursos digitais.

Os pesquisadores focaram sua análise nas interações do público com a área expositiva 'Galeria de Energia', no Science Museum, de Londres. Eles relatam a transformação das atividades dos visitantes por meio de exposições com recursos digitais e a forma como essas atividades possibilitam o compartilhamento de experiências.

A fim de mapear dimensões de engajamento dos públicos, Navas e Pedretti (2015) analisaram as áreas expositivas 'Alertas' e 'Prevenindo a gravidez juvenil', do Catavento Educacional e Cultural, em São Paulo. Considerando o diálogo, a participação e a ação como dimensões emergentes de engajamento, a análise dos dados coletados mostrou que as dimensões dialógicas e participativas de envolvimento do público estiveram presentes durante a visita. As pessoas interagiram, vivenciaram situações de crise e conflito e refletiram sobre as próprias escolhas e os seus desdobramentos futuros.

Giraut e Molinatti (2015), ainda sobre a análise da exposição 'Question of Truth', apresentam alguns elementos expográficos de interação com o público. Eles destacam o dispositivo interativo intitulado "Gênero e Ciência", que convida o visitante a confrontar seus pontos de vista sobre a existência do instinto materno, a poligamia como um produto 
da evolução biológica e o determinismo cerebral das diferenças de habilidade entre homens e mulheres (habilidades de linguagem e orientação no espaço). Os pesquisadores apontam a importância da interação do público com este tipo de dispositivo para um maior envolvimento na questão controversa apresentada.

Para Meyer (2015), os temas controversos revelam realidades sociais. Possuem assim um importante papel político, já que o debate em torno de uma controvérsia muitas vezes leva à criação de novas instituições, grupos, associações, regras e leis. É imprescindível, então, que os museus assumam seu papel social como iniciador e provocador da questão controversa. Quando os museus funcionam apenas como uma caixa de ressonância do discurso científico, eles despolitizam as controvérsias, retirando delas uma característica fundamental (BARTHE, 2011). É necessário apresentar aos visitantes a voz e o ponto de vista da própria instituição museal, que deve ser palco dos processos de comunicação que permitem a mobilização do público ao redor das controvérsias.

\subsection{Experimentação animal: início e vida de uma controvérsia}

É praticamente inegável que o fazer científico consiste em um empreendimento fundamental e necessário, cujos resultados são os principais responsáveis pela diminuição do sofrimento e morte humanos ao longo dos anos. No entanto, também é fato relevante que a pesquisa com animais, cujo principal propósito é a melhoria da vida humana, acaba por prejudicar a vida de tais criaturas e levanta, por sua própria natureza, questões éticas. Podemos afirmar, então, que a controvérsia a respeito da ética na experimentação com animais não gira em torno do valor do seu fim (promover a vida/saúde humana), mas reside na legitimidade dos meios para se atingir esse fim (o uso de animais).

Entende-se por experimentação animal: "procedimento, realizado em animais não humanos, levado a efeito, visando a descobrir princípio ou efeito desconhecido, pesquisar uma hipótese ou ilustrar um princípio ou fato conhecido" (PAIXÃO, 2001). Para delimitar os procedimentos abarcados pelo campo da experimentação animal, Rollin (1998) elencou sete formas atuais de utilização de animais. 1) pesquisa básica; 2) pesquisa aplicada; 3) desenvolvimento de substâncias químicas e drogas terapêuticas;; 4) testes de substâncias, 
quanto à segurança ou graus de toxicidade; 5) uso de animais em instituições de ensino; 6) extração de drogas e produtos biológicos.

Todos esses procedimentos envolvem não só técnicas, metodologias e instrumentos, mas sujeitos imersos em suas concepções, crenças e contextos, o que torna a experimentação animal um tema controverso em diversos âmbitos sociais e abre campo para numerosas discussões éticas. Até onde vai o direito do ser humano sobre outros animais na busca por soluções para problemas antrópicos?

Do escopo de questões como essa suscitam as discussões que embasam os dois quadros gerais de argumentos, contra e a favor, ao uso de animais. Esses argumentos fundamentam-se principalmente em três aspectos-chave:

1) o uso de animais em benefício humano - a senciência e o direito à vida se opõem à existência dos comitês de ética, aos quais são submetidas as pesquisas;

2) a extrapolação dos resultados em animais aos seres humanos - por um lado não se sabe o quanto dos resultados obtidos em testes com animais pode ser extrapolado aos humanos, devido às diferenças biológicas entre os organismos; por outro, há o risco potencial de vidas humanas, caso não fossem feitos os testes primeiramente em animais;

3) a utilização de métodos alternativos - abolicionistas sustentam o fato de que já existem métodos como modelos matemáticos e computacionais, técnicas in vitro de tecidos animais e humanos, que poderiam substituir o uso de animais. A comunidade científica, porém, acredita que esses métodos ainda não abrangem todas as pesquisas necessárias.

As discussões desenrolam-se ao longo dos anos, geralmente pautadas nesses mesmos argumentos, e muitas vezes são reforçadas pela mídia que quase sempre incita a população a escolher um dos lados. O resultado é um debate interminável que gira em torno da comunidade científica e de representantes do direito animal. E que, na maioria das vezes, não possui participação social efetiva. O conteúdo exclusivamente midiático do assunto não fornece subsídios suficientes para que a população se torne apta a discutir, avaliar e opinar sobre o tema. 
É necessário ressaltar que reconhecemos as tantas questões (principalmente filosóficas, sociais e bioéticas) que subsidiam a controvérsia em torno da experimentação animal e não se pretende neste trabalho o aprofundamento em todas elas. Visamos com esta investigação elucidar os aspectos mais relevantes para compreensão e discussão de estratégias que fomentem um diálogo consistente e deliberativo entre as principais vozes envolvidas nessa CSC.

\subsubsection{Experimentação Animal no Brasil: principais desdobramentos}

Não é de hoje que o homem busca compreender até onde vai o seu direito sobre a vida dos animais. Ainda que as discussões em torno da questão tenham surgido com mais força e ganhado um discurso público somente a partir do século XX, alguns filósofos europeus já se perguntavam, no século XVIII, sobre o que hoje chamamos de senciência dos animais. Ou seja, se são capazes de sentir emoções ou sofrer (REGIS; CORNELLI, 2012).

Os primeiros passos rumo à regulamentação da experimentação animal foram dados pela própria comunidade científica em um período de maior reflexão a respeito da questão do uso indiscriminado de animais em pesquisas. Em 1959, os pesquisadores britânicos William Russel e Rex Burch publicaram o livro "The principles of humane experimental technique", fruto de um estudo sistemático sobre técnicas laboratoriais em seus aspectos éticos. A publicação consolidava o que muitos autores chamam de referência conceitual no tocante à experimentação animal, o princípio dos 3R's (ibdem).

Este princípio estabelece a adoção dos conceitos de: replacement (substituição), reduction (redução) e refinement (refinamento). Replacement (substituição) postula que se deve tentar substituir o uso de animais vertebrados por outros animais ou materiais que não sintam dor como plantas, microrganismos ou simulações computacionais. O conceito de reduction (redução) indica uma busca pela diminuição do número de animais utilizados em determinada pesquisa. Por fim, refinement (refinamento) determina formas de lapidação da pesquisa que visam à diminuição da dor e sofrimento causados nos animais. 
O princípio dos 3R's é uma proposta adotada internacionalmente e foi o ponto de partida para que diversos países implementassem leis para a regulamentação do uso de animais em pesquisa, ainda que existam na literatura diversas críticas referentes sobretudo à ideia de diminuição, já que uma redução drástica do número de animais em uma pesquisa pode influenciar brutalmente a confiabilidade das análises estatísticas e os seus resultados (REGIS; CORNELLI, 2012; BAEDER et al, 2012).

É somente a partir da década de 1970, entretanto, que o debate internacional sobre as considerações éticas envolvendo a utilização de animais em pesquisa ganha o público e aumenta de forma acentuada, abarcado pelo movimento ambientalista que cresce principalmente nos Estados Unidos.

Ao longo dos anos, um contingente maior de pessoas adere ao movimento em favor dos direitos dos animais e o debate desse grupo com cientistas ganha destaque na mídia e, consequentemente, na população em geral. Segundo Naconecy (2014), a discordância entre pesquisadores e ativistas (ou animalistas, como chama o autor) passou apenas por refinamentos, mas ainda versam principalmente sobre os principais pontos: 0 status moral dos animais em comparação ao homem; a contribuição das pesquisas nas descobertas científicas; o entendimento da "real necessidade" de um medicamento/produto novo; a definição de quem tem o ônus de justificar o uso de animais em pesquisas; a adequação das atuais diretrizes na pesquisa animal; o direito dos animais.

Os embates causados por essas discordâncias criaram, de certa forma, um contexto motivacional para o aperfeiçoamento, em diversos países, das leis que regulamentavam o uso de animais em pesquisas (PAIXÃO, 2001). Na União Europeia, uma resolução de março de 2009, a 'EU Cosmetic Regulation (EC 1223/2009)', estabeleceu que, a partir de 2013, estariam proibidas a colocação no mercado de produtos cosméticos cuja formulação final, ingredientes ou combinação de ingredientes tivessem sido objetos de ensaios em animais mediante a utilização de um método que não fosse alternativo, validado e aprovado a nível comunitário; e a realização na comunidade de ensaios de produtos cosméticos acabados, ingredientes ou combinações de ingredientes em animais (ANDA, 2014).

Essa resolução é considerada um marco histórico e obrigou grandes empresas de cosméticos a se movimentar em busca de técnicas e métodos alternativos para que 
pudessem comercializar seus produtos na Europa. Outros países, como Israel, Índia e China também possuem legislação proibitiva para testes em animais para o desenvolvimento e produção de cosméticos.

No Brasil, este processo caminhou a passos curtos e, em relação à legislação, é possível observar diversas lacunas, tanto em escala temporal quanto no que se refere ao alcance das medidas regulamentadas.

A primeira norma a regular e proteger os animais foi o Decreto $16.590 / 24$, que proibia, nas casas de diversões públicas, as corridas de bovinos, brigas de aves, bem como toda e qualquer diversão que resultasse em maus-tratos aos animais (MASCHIO, 2005).

Em 10 de julho de 1934, foi criada pelo então presidente Getúlio Vargas, a Lei de Proteção aos Animais (Decreto 24.645), resultado de uma proposta do ministro da Agricultura, Juarez Távora. A crueldade e os maus-tratos aos animais passaram a ser proibidos por lei, sob pena de multa e prisão. Os animais passaram a ser reconhecidos como sujeitos de direito, sendo atribuído a eles, inclusive, representação em juízo pelo Ministério Público e pelas sociedades protetoras de seus interesses (ACKEL, 2001).

Em seguida, foi criada a Lei das Contravenções Penais (Decreto-Lei 3.688 de 03 de outubro de 1941), que proibia a crueldade contra os animais em seu artigo 34. Até a criação dessa lei, a prática desses delitos era considerada apenas uma contravenção. Em 1967, com a criação da Lei 5.197 (Lei de Proteção à Fauna), foram instituídas novas categorias penais criminalizando numerosas condutas nocivas aos direitos dos animais. Esta lei também criou o Conselho Nacional de Proteção à Fauna.

Em virtude da ausência de legislação específica, foi apresentado, em agosto de 1973, o Projeto de Lei 1.507 (BRASIL, 1973), que culminou na criação da Lei 6.638, em maio de 1979, na qual ficavam estabelecidas normas para a prática didático-científica da vivissecção de animais. Essa lei autorizou, em todo o território nacional, a prática de vivissecção de animais, excetuando-se os estabelecimentos de ensino de nível básico. Visando o bem-estar dos animais, a vivissecção também não era permitida sem o emprego de anestesia. 
Em 12 de fevereiro de 1988, com redação dada pela Lei 7.653, passou a ser considerado crime a utilização, perseguição, destruição, caça ou apanha de animais silvestres.

No ano 1998, após diversas tentativas frustradas de conseguir que os maus-tratos aos animais fossem criminalizados, uma instituição de proteção animal, a Liga de Prevenção da Crueldade contra o Animal, editou o livro 'Liberticídio dos Animais' com diferentes imagens e legendas de maus-tratos e o entregou à Comissão de Juristas, aos deputados e senadores que votariam a inclusão da proteção animal na Lei de Crimes Ambientais (DIAS, 2013). Desta vez, o resultado foi favorável, com a inclusão do artigo 32 na Lei 9.605, de 12 de fevereiro de 1998 (BRASIL, 1988):

Art. 32 - Praticar ato de abuso, maus-tratos, ferir ou mutilar animais silvestres, domésticos ou domesticados, nativos ou exóticos: Pena - detenção, de três meses a um ano, e multa.

$\S 1$ 으 - Incorre nas mesmas penas quem realiza experiência dolorosa ou cruel em animal vivo, ainda que para fins didáticos ou científicos, quando existirem recursos alternativos.

§ 2ㅇ - A pena é aumentada de um sexto a um terço se ocorre morte do animal.

Em 2008, foi criada a Lei Arouca (Lei 11.794, de 8 de outubro), revogando a Lei 6.638/79 e criando também o Conselho Nacional de Controle de Experimentação Animal (Concea). O quadro abaixo resume os principais aspectos da legislação brasileira com foco para a proteção animal (Quadro 1). 


\begin{tabular}{|c|c|c|}
\hline DATA & LEGISLAÇÃO & PRINCIPAL MEDIDA \\
\hline $10 / 10 / 1924$ & Decreto 16.590 & $\begin{array}{l}\text { Proibição das corridas de bovino e brigas de aves, nas casas de } \\
\text { diversão pública, bem como toda e qualquer diversão que } \\
\text { resultasse em maus-tratos de animais. }\end{array}$ \\
\hline $10 / 07 / 1934$ & Decreto-lei 24.645 & $\begin{array}{l}\text { Determinação de tutela, pelo Estado, de todos os animais } \\
\text { existentes no país; determinação de sanção àqueles que } \\
\text { praticassem maus-tratos aos animais; compilação dos atos } \\
\text { considerados maus-tratos aos animais. }\end{array}$ \\
\hline 03/10/1941 & Decreto-lei 3.688 & $\begin{array}{l}\text { Tipificação da crueldade contra animais como contravenção } \\
\text { penal, independente dos fins didáticos ou científicos. }\end{array}$ \\
\hline 08/05/1979 & Lei 6.638 & $\begin{array}{l}\text { Estabelecimento de normas para vivissecção como prática } \\
\text { didático-científica, autorizada em todo o território nacional, } \\
\text { exceto em instituições de } 1 \text { ○ e } 2 \% \text { graus e/ou frequentadas por } \\
\text { menores de idade. }\end{array}$ \\
\hline $12 / 02 / 1998$ & $\begin{array}{l}\text { Lei } 9.605 \text { - Lei de } \\
\text { Crimes Ambientais }\end{array}$ & $\begin{array}{l}\text { Garantia de penas mais severas para a prática de maus-tratos } \\
\text { aos animais. }\end{array}$ \\
\hline 21/09/1999 & Decreto 3.179 & $\begin{array}{l}\text { Referência à prática de maus-tratos aos animais ainda que } \\
\text { para fins didáticos e científicos. }\end{array}$ \\
\hline $08 / 10 / 2008$ & Lei 11.794 - Lei Arouca & $\begin{array}{l}\text { Estabelecimento dos procedimentos para uso científicos dos } \\
\text { animais; restrição do uso de animais para fins educacionais às } \\
\text { instituições de ensino superior ou ensino técnico (áreas } \\
\text { biomédicas) }\end{array}$ \\
\hline $15 / 07 / 2009$ & Decreto 6.899 & $\begin{array}{l}\text { Regulamentação da Lei Arouca; criação do Conselho Nacional } \\
\text { de Controle de Experimentação Animal (Concea); } \\
\text { determinação da obrigatoriedade das comissões de ética no } \\
\text { uso de animais (Ceua) nas instituições que realizam ou } \\
\text { desejam realizar pesquisas em animais. }\end{array}$ \\
\hline
\end{tabular}

Quadro 1 Principais regulamentações que estabelecem medidas de proteção aos animais no Brasil

O panorama legislativo apresentado é marcado por avanços e retrocessos - ora as práticas didático-científicas com uso de animais são classificadas como maus-tratos, ora são autorizadas, por exemplo. Essas lacunas davam margem a uma série de procedimentos que muitas vezes ultrapassavam os limites éticos e, somados à falta de fiscalização do cumprimento das leis, deixavam as instituições de pesquisa praticamente autônomas em relação a essa questão.

Foi apenas no ano de 2008 que os procedimentos didático-científicos foram de fato descritos e regulamentados, através da Lei Arouca, considerada o marco regulatório da experimentação animal no Brasil. Com forte influência do princípio dos 3R's, esta lei e seu posterior decreto de regulamentação causaram um impacto expressivo no âmbito da comunidade científica, principalmente com a criação do Conselho Nacional de Controle de Experimentação Animal (Concea). 
Órgão integrante do Ministério da Ciência Tecnologia e Inovação (MCTI), o Concea é o responsável por autorizar pesquisas com animais e formular normas para que sejam realizadas de forma ética e humanitária. Além disso, estabelece procedimentos para instalação e funcionamentos de biotérios e laboratórios de experimentação animal ${ }^{1}$. Também é papel deste órgão cadastrar e regulamentar as Comissões de Ética no Uso de Animais (Ceua), que existiam desde a década de 1990, mas se tornaram obrigatórias com a regulamentação da Lei Arouca.

As comissões de ética são hoje o principal instrumento de controle do uso de animais no âmbito das instituições científicas. Devem ser integradas por médicos veterinários e biólogos; docentes e pesquisadores da área específica; e representantes de organizações protetoras dos animais. Embora possuam funções diversas, o papel principal dessas comissões é "assegurar que os animais sob a sua supervisão estejam sendo mantidos e utilizados de uma forma humanitária" (PAIXÃO, 2001, p. 38).

Alguns aspectos se destacam nas discussões sobre o papel e a pertinência dessas comissões de um modo geral. O principal deles refere-se ao fato de que elas têm como ponto de partida a ideia de que toda pesquisa animal é justificada, desde que conduzida da melhor forma possível, levando-se em conta os objetivos da pesquisa (RUSSOW, 1998). Isso faz com que certas organizações abolicionistas entendam o papel desses comitês não como uma forma de "controle", mas como uma forma de "legitimar" o uso de animais e, portanto, colocam-se em oposição à própria existência desses comitês e recusam-se a participar desse processo (GREIF; TRÉZ, 2010).

As discussões em torno da legislação brasileira em relação à experimentação animal não se encerraram com a criação da Lei Arouca. Em 2013, após o episódio conhecido como a 'libertação dos beagles²', o Estado de São Paulo aprovou o projeto de lei que proíbe a utilização de animais para desenvolvimento, experimentos e testes de produtos cosméticos, higiene pessoal, perfumes e seus componentes. O assunto foi discutido na Assembleia Legislativa do Estado, em audiência pública, quando os participantes elencaram

\footnotetext{
${ }^{1}$ Ver: http://www.cobea.org.br/conteudo/view?ID_CONTEUDO=41

2 Trataremos deste episódio com mais detalhes na sessão seguinte.
} 
diversos métodos substitutivos para a vivissecção, enquanto alguns pesquisadores apontaram dificuldades na substituição do uso de animais. São Paulo é o primeiro estado do Brasil a adotar uma legislação que veta o uso de animais em testes laboratoriais de produtos estéticos em desenvolvimento. Os testes com animais envolvendo questões de saúde ainda podem ser realizados.

No mesmo ano, a Frente Parlamentar em Defesa dos Direitos dos Animais apresentou o Projeto de Lei 6602/13. O projeto previa a alteração dos parágrafos 7ํ, 8으, 9 e 10 do artigo 14 da Lei Arouca e, a exemplo de São Paulo, a proibição dos testes em animais para a produção de cosméticos nacionalmente:

Art. 14.

§ 70 É vedada a utilização de animais de qualquer espécie em atividades de ensino, pesquisas e testes laboratoriais com substâncias que visem o desenvolvimento de produtos de uso cosmético em seres humanos (BRASIL, 2013).

Entretanto, após sofrer uma forte pressão política, a Frente se viu obrigada a alterar o teor do projeto para que fosse aprovado no Congresso. O conteúdo final, enviado para apreciação no Senado Federal como PLC 70/14, causou indignação nos defensores dos direitos dos animais que alegaram um retrocesso à pouca proteção já conferida aos animais no Brasil e às conquistas obtidas na legislação em vigor.

Art. 14.

§ 70 É vedada a utilização de animais de qualquer espécie em atividades de ensino, pesquisa e testes laboratoriais que visem à produção e ao desenvolvimento de produtos cosméticos e de higiene pessoal e perfumes quando os ingredientes tenham efeitos conhecidos e sabidamente seguros ao uso humano ou quando se tratar de produto cosmético acabado nos termos da regulamentação da Agência Nacional de Vigilância Sanitária.

$\S 8$ o No caso de ingredientes com efeitos desconhecidos, será aplicada a vedação de utilização de animais de que trata o $\S$ 7으, no período de até 5 (cinco) anos, contado do reconhecimento de técnica alternativa capaz de comprovar a segurança para o uso humano (BRASIL, 2014). 
Diversas lideranças e especialistas em direitos dos animais, incluindo advogados, promotores de justiça, biólogos e filósofos, se reuniram em uma campanha chamada 'Altera PL 6602' para apontar e justificar os diversos pontos de discordância do PLC 70/14 na tentativa de alterar seu conteúdo antes da votação no Senado. A principal questão do embate é que o Projeto de Lei original possuía caráter abolicionista, proibindo todos os testes em animais para fins de pesquisa e desenvolvimento de cosméticos, enquanto o PL substitutivo abre algumas lacunas que viabilizam o uso de animais, proibindo os testes apenas para substâncias que já são conhecidamente seguras para seres humanos e fornecendo um prazo considerado longo para a utilização de uma técnica alternativa após seu reconhecimento.

Em setembro do ano passado, após numerosas audiências públicas e a reunião de mais de onze mil assinaturas, o relator da matéria na Comissão de Ciência, Tecnologia, Inovação, Comunicação e Informática (CCT), senador Cristovam Buarque, publicou o relatório que altera o PLC 70/14. Os principais pontos da alteração no texto são: 1) Não há mais o prazo de cinco anos contando do reconhecimento de técnica alternativa capaz de comprovar a segurança para uso humano. Caso vire lei do jeito que está, o texto garante que em três anos após sua sanção ficará proibido qualquer teste em animais para produtos cosméticos, independentemente se há ou não técnica alternativa. Na prática, se uma empresa não conseguir comprovar a segurança do cosmético sem usar animais, não poderá comercializar o produto no Brasil; 2) O novo texto define o que são cosméticos, não deixando brechas sobre isso. 3) Houve a inclusão da proibição da venda de ingredientes ou produtos cosméticos testados em animais.

O texto segue em tramitação pelas comissões do Senado e deve voltar para a Câmara dos Deputados nos próximos meses. Caso seja aprovado e sancionado do jeito que está, será um novo marco para a legislação de proteção aos animais no Brasil. 
Portanto, acreditamos que, para uma participação pública efetiva, com resultados a maior prazo, são necessários levantamentos mais transversais, ao longo do tempo, que envolvam momentos em que o tema não estampa os noticiários.

Compreender o que as pessoas pensam sobre determinado assunto é o primeiro passo para elaboração e desenvolvimento de ações direcionadas. Saber a percepção pública acerca do uso de animais em pesquisas é, então, fundamental para que ações de divulgação e comunicação pública da ciência com maior participação social possam ser implementadas.

Atualmente, apesar das críticas $^{3}$, a estratégia mais utilizada para pesquisas de percepção pública é o survey. Este instrumento de coleta de dados quantitativos foi legitimado por pesquisadores e profissionais das esferas pública e privada para conhecerem as principais tendências de opinião e o comportamento geral, constituindo-se assim, em um canal de conhecimento sobre valores e atitudes além de aspectos específicos de ciência e tecnologia (C\&T). Ao longo dos anos os surveys foram sendo aprimorados e hoje é quase uma unanimidade considerar que podem ser bons indicadores para a orientação de políticas públicas (FREITAS et. al, 2000).

Em relação às questões científicas, a National Science Foundation (NSF), nos Estados Unidos, foi pioneira quando, já na década de 1970, incluía aos medidores clássicos de C\&T, investigações que buscassem medir a percepção do público sobre ciência e tecnologia (VOGT et al, 2005). Hoje, países da União Europeia, Austrália, Canadá, EUA, Grã-Bretanha e Japão realizam regularmente pesquisas sobre a percepção e compreensão da Ciência (ibdem). Essas pesquisas, realizadas com milhares de pessoas, geram dados preciosos para que pesquisadores da área de comunicação científica, conhecida também como Public Understanding of Science, possam não só compreender o que as pessoas pensam a respeito de assuntos ligados a temas científicos, mas inferir e se aprofundar em investigações que expliquem quais os principais fatores que influenciam essa percepção pública.

\footnotetext{
${ }^{3} \mathrm{Alguns}$ especialistas criticam o fato dos surveys serem muito pontuais e apontam a necessidade de pesquisas que acompanhem o mesmo sujeito ao longo do tempo, para um resultado mais significativo sobre a sua percepção sobre o tema, já queas diversas experiências vividas por um indivíduo podem influenciar sua opinião.
} 
Nesse sentido, pesquisadores europeus têm somado esforços para tentar explicar que aspectos seriam os responsáveis - ou mais fortemente influenciariam - a percepção pública acerca da experimentação animal. Hagelin e colaboradores (2003) revisaram os resultados de 56 surveys, realizados nos EUA, Canadá e Europa, que incluíam questões sobre o uso de animais em testes durante os anos 1980 e 2001, a fim de apresentar e discutir alguns fatores que poderiam influenciar seus resultados.

De acordo com os autores, esses fatores podem ser divididos em dois grupos: 1) relacionados ao instrumento de coleta utilizado (questionário do survey); 2) relacionados aos respondentes. Dentro do primeiro grupo, os pesquisadores destacam os seguintes aspectos:

- informações dadas aos entrevistados pelo entrevistador como: justificativas da investigação, objetivos, natureza dos experimentos atuais podem influenciar as atitudes à experimentação animal;

- formulação da pergunta: escritas diferentes para a mesma questão provocam respostas diferentes dentro da mesma população;

- referência, sobre a finalidade da pesquisa com os animais: surveys que questionam sobre o uso de animais para pesquisas médicas (para produção de vacinas ou medicamentos) possuem maior aceitação que aqueles que citam pesquisas psicológicas e comportamentais por exemplo;

- especificação na entrevista do animal utilizado. Surveys que especificavam o uso de cães, gatos e primatas não humanos resultavam em menor aceitação que os que incluíam roedores. Segundo os autores, cães e gatos são vistos como pet, enquanto roedores como pragas;

- citação da palavra "dor" na entrevista: as populações amostradas são menos propensas a aceitar a experimentação animal se as palavras "dolorosas" ou "morte" estiverem incluídas nas perguntas.

No grupo dos fatores relacionados ao respondente, os resultados apontam que os aspectos que mais influenciam as respostas são:

- idade: pessoas mais jovens tendem a aceitar menos que as mais velhas; 
- gênero: mulheres aceitam menos o uso de animais em pesquisas que os homens. Estudos que tentam explicar esta diferença se concentram principalmente em variações no grau de socialização4;

- localização geográfica no país: pessoas que moram em áreas mais urbanas tendem a aceitar menos que aquelas que moram em áreas rurais. Isso pode ocorrer devido à relação homem-animal ser diferente nessas duas áreas;

- religião: segundo os autores, pessoas de religiões monoteístas aceitam mais a experimentação animal que as de religiões politeístas. Estudos que se aprofundam nesta questão se concentram na relação de hierarquia entre homens e outros animais, que é diferente nos dois grupos;

- posse de animal de estimação: respondentes que possuem animais de estimação aceitam menos que os que não possuem;

- hábito alimentar: a aceitação é menor entre pessoas vegetarianas/veganas;

- ambientalismo: de acordo com a pesquisa, pessoas que estão mais envolvidas com questões ambientais aceitam menos a experimentação animal que as demais;

- educação: quanto maior o nível educacional do entrevistado maior a chance dele aceitar o uso de animais em pesquisas;

- experiência prática: pessoas que de alguma forma tiveram contato com experimentos em animais aceitam mais que aquelas que não tiveram.

Os estudos de Hagelin e seus colaboradores (2003) foram norteadores para outros pesquisadores que buscavam investigar essas questões. A partir de seus resultados, diversas pesquisas foram realizadas incluindo etapas qualitativas, principalmente por meio de grupos focais, para um aprofundamento maior na busca de explicações dos fatores que poderiam influenciar a percepção do público acerca da experimentação animal.

Neste cenário, destacam-se os estudos de Von Roten $(2008,2013)$ que analisa o banco de dados de dois importantes surveys europeus: o International Social Survey Program (ISSP) e o Eurobarometer (EB) Science. Com os dados obtidos, a autora analisa mais profundamente o efeito do especismo, ou seja, a preferência por algumas espécies

\footnotetext{
${ }^{4}$ A questão do gênero como fator influenciador da opinião pública a respeito da experimentação animal será melhor explicado no capítulo 8 desta dissertação.
} 
em detrimento a outras para estudos com animais e compila o trabalho de diversos pesquisadores que, a partir de estudos qualitativos, se aprofundaram na tentativa de explicar o que ela chama de fatores extrínsecos ao survey, nomeadamente: gênero, educação, valores e atitudes em relação à ciência.

A pesquisadora também inclui aos fatores chamados intrínsecos ao survey, além daqueles já citados como relacionados ao questionário por Hagelin, a citação ou não de métodos alternativos na entrevista. Além disso, afirma que outro fator é extremamente relevante ao considerar as respostas dos entrevistados: a importância da pesquisa animal em seu país ou o tipo de regulamentação que rege a experimentação animal.

Em relação ao Brasil, encontramos apenas dois surveys que se referem à questão da experimentação animal, ambos realizados pelo Instituto Datafolha. O primeiro, publicado em outubro de 2013, logo após o episódio dos beagles, em São Roque (SP), abrangeu apenas a população paulistana. As questões permearam o nível de informação dos entrevistados sobre o acontecimento e de aceitação dos experimentos com cães, macacos, ratos e coelhos em pesquisas científicas para o desenvolvimento de medicamentos e tratamentos para seres humanos. Ou seja, para fins médicos.

Os dados divulgados pelo instituto indicam certo nível de especismo: a maioria da população é contra pesquisas realizadas em cães (66\%), macacos (59\%) e coelhos (57\%). Já a utilização de ratos para experimentos científicos contou com a aprovação de $66 \%$ da população paulistana.

O Datafolha também divulgou os resultados de cruzamentos entre a aceitação dos animais em experimentos e a idade dos entrevistados. Sobre esse assunto pode-se perceber que, de um modo geral, os mais velhos são mais favoráveis ao uso de animais em pesquisas científicas, enquanto os mais jovens se declaram mais contrários. Entre os entrevistados com 60 anos ou mais, 38\% são a favor do uso de cães (no total das faixas etárias, $29 \%$ ), $41 \%$ do uso de macacos (são $34 \%$ no total), $46 \%$ do uso de coelhos (contra $37 \%$ do total) e $73 \%$ do uso de ratos (no total são 66\%) em testes científicos. Entre os que possuem entre 16 e 24 anos de idade, 78\% são contra a utilização de cães (contra 66\% do total das faixas etárias), $69 \%$ do uso de coelhos (no total são $57 \%$ ), $68 \%$ do uso de macacos (são $59 \%$ no total), e $38 \%$ do uso de ratos em experimentos (no total, $29 \%$ ). 
Em dezembro de 2014, o site $\mathrm{G} 1^{5}$ divulgou outra pesquisa do Datafolha sobre a opinião pública acerca da experimentação animal, dessa vez a nível nacional. A pesquisa foi encomendada pelo Instituto de Ciência, Tecnologia e Qualidade (ICTQ), entidade de pósgraduação para farmacêuticos.

Segundo o levantamento, $54 \%$ dos cidadãos brasileiros concordam em algum grau com o uso de animais pela ciência ( $36 \%$ concordam plenamente e $18 \%$ concordam parcialmente com essa aplicação), enquanto $41 \%$ dos entrevistados discordam totalmente. Foram entrevistadas 2.162 pessoas em 134 cidades por todo o país.

Seguindo a mesma tendência do estudo anterior, quanto mais jovem a população, maior é a oposição ao uso de animais em pesquisas. Os dados apontam que entre os jovens de 16 a 24 anos, por exemplo, apenas $29 \%$ concordam com os testes em animais. Já a partir dos 40 anos de idade, essa parcela passa a ser de $40 \%$.

A opinião também variou conforme a região do país. O Sul registrou o menor índice de aprovação em relação aos testes em animais: $32 \%$ dos residentes concordam com o procedimento. No Sudeste e no Nordeste, esse índice é de 36\%. No Norte e Centro-Oeste, 38\% das pessoas aprovam os testes.

Esses estudos são de suma importância para as discussões que envolvem o uso de animais em pesquisas. Todavia, ainda são necessárias pesquisas que utilizem esses dados para um aprofundamento no que se refere aos fatores que determinam a percepção dos brasileiros sobre o tema. Além disso, é fundamental que esses resultados sejam convertidos em ações de comunicação pública da ciência que resultem na participação efetiva da sociedade na tomada de decisão dos assuntos referentes à C\&T.

\footnotetext{
${ }^{5}$ Ver: http://g1.globo.com/ciencia-e-saude/noticia/2014/12/no-brasil-41-da-populacao-e-contra-testescom-animais-revela-pesquisa.html
} 
Também contribuem para o entendimento das percepções do público as pesquisas qualitativas, importantes instrumentos para a análise de temas controversos. A profundidade desse tipo de pesquisa fornece uma configuração mais consistente sobre os posicionamentos dos sujeitos, evidenciando como se relacionam os elementos que constituem suas percepções e de que maneira se engendram os conflitos. Por isso, no próximo capítulo discutiremos como o método dialético na perspectiva marxista contribui na análise da questão da experimentação animal, revelando, do ponto de vista dos sujeitos, as unidades, relações e tensões inerentes a essa controvérsia. 


\section{REFERENCIAL TEÓRICO}

Neste capítulo, apresentamos a dialética, método que se mostrou mais coerente para a análise do fenômeno estudado, pois possibilita a superação da dualidade causada pela percepção sensível da controvérsia da experimentação animal. Após um breve histórico do desenvolvimento da dialética, apresentamos o materialismo históricodialético de Marx e sua influência no pensamento e estudos de Vigotski sobre a consciência humana. Essa influência está relacionada principalmente ao desenvolvimento dos conceitos de atividade e mediação, que aprofundados por teóricos da escola vigotskiana fundamentam a Teoria da Atividade (TA).

Apresentamos e discutimos ainda neste capítulo, o arcabouço teórico da TA a partir de uma ótica histórica e conceitual. Para tanto, descrevemos o contexto histórico a partir do qual esse arcabouço foi gerado, seu desenvolvimento a partir dos trabalhos de Leontiev, principalmente, e seu estágio atual tal como proposto pelo pesquisador Yrjö Engeström.

\subsection{Dialética: origem e fundamentos}

Conhecida na Grécia Antiga como a 'arte de dialogar', a palavra dialética expressava um modo específico de argumentar pautado na descoberta das contradições contidas no raciocínio do adversário - análise - negando, assim, a validade de sua argumentação e superando-a por outra - síntese (GADOTTI, 1990). Sócrates, considerado o maior dialético da Grécia, utilizava-se do ceticismo, da dúvida sistemática e por meio de análises e sínteses esclarecia os termos da questão em disputa, fazendo revelar a verdade. Para ele, a dialética era capaz de fornecer os instrumentos indispensáveis para o conhecimento da essência de um fenômeno (KONDER, 1981).

Mas o sentido atual do termo dialética surge antes de Sócrates. Heráclito de Efeso foi o pensador dialético que incorporou a noção de movimento à dialética de maneira mais radical. Ele entendia que a realidade é composta por uma luta de opostos: é por meio do conflito que todas as coisas mudam, que tudo está em constante transformação. Heráclito negava a existência de qualquer estabilidade do ser (LLANOS, 1988). 
Como é possível observar, a questão fundamental e que dá origem à dialética é a explicação do movimento, da transformação das coisas. Essa visão dinâmica da realidade é completamente oposta à metafísica, na qual o universo é apresentado como um "aglomerado de entidades distintas que, embora relacionadas entre si, possuem individualidade própria e exclusiva que não depende das demais entidades" (PRADO Jr., 1963 apud GADOTTI, 1990).

A dialética, por outro lado, considera todas as coisas em movimento, intimamente relacionadas umas com as outras. Para Platão, a dialética era um método de ascensão ao inteligível, pelo qual era possível a redução racional das ideias (ZAGO, 2013). O pensador defendia que a dialética era uma técnica de pesquisa na qual o conhecimento provinha da reflexão coletiva, da disputa e não do isolamento.

Já Aristóteles explicava o movimento das coisas por meio dos conceitos de ato e potencialidade. Para ele, o movimento é uma potencialidade preexistente que se atualiza, se transforma em uma realidade concreta. Foi essa linha de raciocínio que convenceu os filósofos da época a não abandonarem os estudos da dimensão dinâmica e mutável do real. Aristóteles, ao contrário de Platão, não acreditava que a dialética era um método pelo qual era possível chegar à verdade e ao conhecimento, e reduziu-a à sua atividade crítica, um método que conduz à disputa e à opinião (KONDER, 1981; GADOTTI, 1990).

Durante os séculos da Idade Média, a dialética foi ficando cada vez mais à margem da filosofia, tornando-se bastante enfraquecida. Apenas no século III d.C. o debate em torno da dialética ressurge. Segundo Leandro Konder:

\footnotetext{
A concepção metafísica prevaleceu, ao longo da história, porque correspondia, nas sociedades divididas em classes, aos interesses das classes dominantes, sempre preocupadas em organizar duradouramente o que já está funcionando, sempre interessadas em 'amarrar' bem tanto os valores e conceitos, como as instituições existentes, para impedir que os homens cedam à tentação de querer mudar o regime social vigente (1981, p. 19).
}

O caráter instável, dinâmico e contraditório da condição humana - elementos que são substanciais da dialética e opostos à concepção da metafísica - volta a criar forma com o filósofo iluminista Diderot (ibden). Diderot observou que o movimento do indivíduo está 
condicionado a um movimento ainda mais amplo: as mudanças sociais. Logo, as mudanças do todo transformam o indivíduo e o todo está constantemente em transformação.

Essas ideias também eram compartilhadas pelo filósofo e pedagogo Jean-Jacques Rousseau. Apesar de discordar em alguns aspectos com Diderot, Rousseau também acreditava no condicionamento do indivíduo pela sociedade que, democraticamente, seria capaz de levar o homem a desenvolver-se plenamente (Gadotti, 1990).

Mas é só a partir de Hegel que a dialética retorna com enérgica vitalidade na filosofia moderna. A dialética, segundo ele, é aquilo que tem a possibilidade de negar-se a si mesma (MARCONI; LAKATOS, 2003). De acordo com seu conceito de superação dialética, a realidade é negada e, ao mesmo tempo que se conserva algo essencial dessa realidade negada, ela é elevada a um nível superior, em um processo contínuo.

A afirmação gera a sua negação, contudo a negação não se perpetua, pois tanto a afirmação quanto a negação são superadas, gerando uma síntese que se constitui como negação da negação, da negação recíproca, surge a 'negação da negação': a superação. (LEFEBVRE, 1991, p.231)

Hegel concebe a razão como um processo dialético no qual a contradição é considerada, logicamente, um motor do pensamento, ao mesmo tempo que é o motor da própria história, já que a história é o pensamento que se realiza concretamente (GIANNOTTI, 2010).

O pensamento não é mais estático, mas procede por contradições superadas, da tese (afirmação) à antítese (negação) e daí à síntese (conciliação). Uma proposição (tese) não existe sem oposição a outra proposição (antítese). A primeira proposição será modificada nesse processo de oposição e surgirá uma nova. A antítese está contida na própria tese que é, por isso, contraditória. A conciliação existente na síntese é provisória na medida em que ela própria se transforma numa nova tese (GADOTTI, 1990, p. 18).

A dialética de Hegel, contudo, fechava-se no mundo do espírito, às leis do pensamento. Para Hegel, a essência do homem era determinada pela consciência humana, em um movimento espiritual que ocorre no interior do entendimento humano (KONDER, 1981). Nessa visão idealista, a história é concebida como uma sucessão de momentos, que 
seguem adiante somente por meio da oposição ao momento anterior em uma contínua "marcha da razão", sendo que o sujeito histórico é abstrato, é o "sujeito em si mesmo" (SANTA; BARONI, 2014). Os movimentos da realidade hegeliana estão subordinados à lógica do princípio de Ideia Absoluta, que, mesmo incapaz de abarcar todos os aspectos da vida social - mantendo-se no campo das ideias -, abriu caminho para os estudos de Marx.

\subsubsection{O materialismo dialético de Marx}

Marx e Engels superam dialeticamente o idealismo de Hegel e conferem à dialética um caráter materialista. "Não é a consciência do homem que determina o seu ser, mas pelo contrário, o seu ser social é que determina a sua consciência" (Marx, 1977, vol. I p.301). Enquanto a dialética de Hegel fechava-se no mundo espiritual, Marx inverte essa concepção e coloca a matéria no centro da dialética. Para ele, a dialética explica a evolução da matéria, da natureza e do próprio homem; é a ciência das leis gerais do movimento, tanto do mundo exterior como do pensamento humano.

\footnotetext{
[...] na produção social da sua vida, os homens contraem determinadas relações necessárias e independentes da sua vontade, relações de produção que correspondem a uma determinada fase de desenvolvimento das suas forças produtivas materiais. $O$ conjunto dessas relações de produção forma a estrutura econômica da sociedade, a base real sobre a qual se levanta a superestrutura jurídica e política e à qual correspondem determinadas formas de consciência social. O modo de produção da vida material condiciona o processo da vida social, política e espiritual em geral (MARX, 1977, v. 1 p. 301).
}

A condição para que o homem se torne homem (porque ele não é, ele se torna) é o trabalho, a construção da sua história. A mediação entre ele e o mundo é a atividade material.

Para Hegel processo de pensamento que ele transforma em sujeito autônomo, sob o nome de ideia, é o criador do real, e o real é apenas sua manifestação externa. Para mim, ao contrário, o ideal não é mais que o material transposto para a cabeça do ser humano e por ela interpretado (1972, vol. 1:16).

O que distingue Marx e Hegel, neste ponto, é a explicação do movimento. Ambos sustentam a tese de que o movimento se dá pela oposição dos contrários, isto é, pela 
contradição. Mas, enquanto Hegel localiza o movimento contraditório na Lógica, Marx o localiza no seio da própria coisa, de todas as coisas, e em íntima interação com elas (SANTA; BARONI, 2014). A esse método de análise da realidade, pautado em um constante movimento cujas raízes são as condições materiais de existência, convencionou-se chamar de materialismo histórico-dialético: a sociedade está estruturada a partir das relações correspondentes a cada período histórico, cuja evolução se desenvolve dialeticamente.

No materialismo, portanto, a compreensão do real se efetiva ao atingir, pelo pensamento, um conjunto amplo de relações, particularidades, detalhes que são captados numa totalidade. A dialética trata de sistemas em movimento através do tempo, os elementos de uma contradição dialética se relacionam entre si dentro da estrutura do movimento, historicamente (ENGESTRÖM; SANNINO, 2011). Dessa forma, só há dialética se existir movimento e só há movimento se houver um processo histórico. A história se apresenta como o movimento de um conteúdo, engendrando diferenças, polaridades, conflitos, problemas teóricos e práticos e resolvendo-os (ou não) (MASSON, 2007).

\subsection{0 método dialético}

Segundo Nepomuceno (2014), ao se aprofundar nas obras de Marx sobre o sistema capitalista de produção é possível observar que o autor propõe algumas categorias que formariam o arcabouço de seu método de análise. Estas categorias são compreendidas como unidade de contrários e foram exemplificadas exaustivamente em seus estudos: 'simples versus complexo', 'concreto versus abstrato', 'particular versus geral', 'individual versus social' etc. Marx não reduz essas categorias às leis fixas do pensamento, mas as considera fundamentais para a compreensão da transformação das coisas, da dinâmica mutável do real.

Engels, contudo, deixa em suas obras de uma forma mais explícita a formulação de três leis gerais da dialética: 1) lei da mudança quantitativa em qualitativa; 2) lei da luta dos contrários; 3) lei da negação da negação (ENGELS, 1976 apud GADOTTI, 1990). Apesar das inúmeras críticas a essa classificação, alguns princípios gerais da dialética dela oriundos são 
hoje aceitos como ponto de partida para a compreensão e aplicação do método dialético (MARKONI E LAKATOS, 2003):

1) Princípio da totalidade (Lei da ação recíproca)

Para a dialética a natureza não se apresenta como um conjunto de coisas isoladas e independentes, mas como um todo coerente onde objetos e fenômenos são ligados entre si, condicionando-se reciprocamente. O método dialético considera essa ação recíproca e investiga os objetos e fenômenos buscando entendê-los numa totalidade concreta.

2) Princípio do movimento

A dialética considera todas as coisas em movimento, qualidade inerente à realidade. $\mathrm{A}$ natureza e a sociedade não são entidades acabadas, mas em contínua transformação. Portanto, na dialética, os fenômenos não são analisados como objetos fixos, mas em movimento, pois sempre estão em vias de se transformar e se desenvolver, e a causa dessa transformação é a luta interna dos opostos.

3) Princípio da mudança qualitativa

A transformação das coisas não se realiza num processo circular de eterna repetição, uma repetição do velho. A mudança qualitativa acontece pelo acúmulo de elementos quantitativos que, num dado momento, produzem o qualitativamente novo.

4) Princípio da contradição

A transformação das coisas só é possível porque no seu próprio interior coexistem forças opostas tendendo ao mesmo tempo à unidade e à oposição. É o que se chama de contradição, que é universal, inerente a todas as coisas materiais e espirituais. A contradição é a essência, a lei fundamental da dialética.

Essas leis ou princípios da dialética não surgiram a priori, mas são fruto do amadurecimento e do próprio desenvolvimento das ciências modernas. Como afirma Gadotti (1990), essas categorias surgem em Marx, após uma análise exaustiva do modo de produção capitalista, consequência de uma análise científica. Só depois de concluído o 
trabalho é que Marx ressaltou o caminho (método) que ele percorreu, manifestou seu método "natural", concreto, não abstrato (NOVELLI, 1998).

A teoria marxista estabelece que o estudo da essência de determinado fenômeno se dá pela análise da forma mais desenvolvida alcançada por tal fenômeno (DUARTE, 2000). Contudo, a essência do fenômeno não se apresenta ao pesquisador imediatamente, por isso é necessário realizar a mediação pelo processo de análise, que se caracteriza como abstração. Desse modo, o método é dialético, pois a apropriação do concreto pelo pensamento científico se dá pelo complexo de mediações teóricas abstratas para se chegar à essência do real, e é materialista porque o conhecimento científico se constrói pela apropriação da essência da realidade objetiva.

Já que a apreensão da realidade pelo pensamento não ocorre de maneira imediata, deve-se desenvolver todo um complexo de mediações teóricas, extremamente abstratas para se chegar à essência do real (KONDER, 2004). Dessa maneira, para se ter uma visão do todo, é necessário decompô-lo em suas partes, fazer uma análise a partir das mediações e contradições que o compõem.

O pensamento, entretanto, vai além em seu percurso. Ele terá que fazer o caminho inverso, ascendendo das abstrações simples à complexidade do todo que, antes, foi representado de forma caótica (DUARTE, 2000).

O trabalho analítico com as categorias mais simples e abstratas seguirá agora o percurso do progressivo enriquecimento da teoria interpretativa da realidade, até atingir novamente o todo que foi o ponto de partida, só que esse todo já não mais se apresenta ao pensamento como uma representação caótica, mas como uma rica totalidade de determinações e relações diversas. (DUARTE, 2000, p. 92).

Somente a partir dessa análise é possível produzir, por meio do pensamento científico, o concreto, reconstruído das complexas relações que constituem o objeto de pesquisa, emergindo assim o concreto pensado.

Restringir-se à sensibilidade do mundo exterior objetivo é desprezar o racional que contribui para que se conheça a essência, as contradições inerentes aos fenômenos que a compõe. A apreensão de uma totalidade tem início na materialidade, contudo não se encerra nela. Submetendo a experiência ao 
movimento de abstração preenchido por conceitos e categorias lógico-racionais permite-se abarcar o caráter histórico que se eleva, ativa e constantemente, da prática à teoria, para depois, abastecido das múltiplas determinações encontradas no processo, retornar à realidade objetivando modificá-la (NEPOMUCENO, 2014, p. 21).

Aprofundar o conhecimento sobre a realidade exige, portanto que, dialeticamente, se supere o grau da percepção sensível, empírica, à racionalidade.

\subsection{A dialética em Vigotski e o conceito de atividade}

O materialismo histórico-dialético, entendido como método de leitura da realidade em seu desenvolvimento histórico, representou para Vigotski uma importante ferramenta na tarefa de estabelecer um modelo científico de estudo dos fenômenos psíquicos. Vigotski encarava o marxismo como uma ferramenta de pensamento, um subsídio indispensável para a elaboração de suas teorias (SANTA; BARONI, 2014). Seguindo os passos de Marx, estabeleceu o homem como ser histórico, sujeito ativo na construção de si mesmo e da própria história.

Para a construção de uma psicologia verdadeiramente científica, "Vigotski entendia ser necessária uma teoria que realizasse a mediação entre o materialismo dialético, enquanto filosofia de máximo grau de abrangência e universalidade, e os estudos sobre os fenômenos psíquicos concretos" (DUARTE, 2000, p. 80). Assim, tendo como base o método dialético, Vigotski pretendeu identificar as mudanças qualitativas do comportamento que ocorrem no decorrer do desenvolvimento biológico e a relação que ele estabelece com o contexto social, focando no estudo das funções psicológicas superiores que distinguem o homem dos animais.

Foi durante esses estudos que Vigotski desenvolveu os conceitos de atividade e mediação, que se aproximam intimamente com o trabalho, na perspectiva marxista. Essa relação se configura como evidência relevante das raízes marxistas no pensamento de Vigotski. No marxismo, o trabalho desempenha um papel determinante: é a atividade essencial do ser humano. É na ação sobre o mundo objetivo que o homem se manifesta 
como "verdadeiro ser genérico" (MARX, 2006, p. 117). Isto é, por meio da sua intervenção na natureza, o homem distanciou-se dos animais - cuja relação com a natureza é direta e imediata - criando meios para a satisfação de suas necessidades, constituindo sua humanidade por meio do trabalho. Conforme afirmam Santa e Baroni:

Os processos dialéticos que diferenciam os homens dos animais são, portanto, aqueles capazes de produzir historicidade: para o marxismo o trabalho enquanto instrumento mediador entre homem e natureza é a gênese da história (2014, p. 10).

É arcabouço dessa ação do homem sobre a natureza o conceito da atividade desenvolvida socialmente, como princípio para a compreensão da consciência humana, objeto de estudo da psicologia (Bizerra, 2009). Vigotski, ao estudar o comportamento humano e a mente, os considera mais como ações intencionais e significativas do que como reações biológicas. Partindo do princípio de que os elementos da experiência humana são socialmente e culturalmente significativos, a atividade substitui o hífen na relação sujeitoobjeto, transformando-a na fórmula sujeito-atividade-objeto, na qual ambos, sujeito e objeto, são historicamente e culturalmente especificados (KOZULIN ${ }^{6}, 1986$ apud BIZERRA, 2009).

No entendimento de Vigotski, a atividade é um componente de transformação do meio a partir de instrumentos. No decorrer da história, os conhecimentos, as aptidões e a prática humana consolidaram-se nas suas realizações - materiais e intelectuais (LEONTIEV, 1978). O homem, então, se relaciona com a realidade que o cerca por meio do conhecimento construído pelas gerações que o precederam, mediado pelos instrumentos materiais e simbólicos presentes na cultura (SANTA; BARONI, 2014). O conceito de atividade era, dessa forma, intimamente ligado ao conceito de mediação (RIVIÈRE, 1985).

Pesquisadores que se dedicaram a investigar as raízes marxistas nas obras de Vigotski (SAVIANI, 1996, DUARTE, 1993, 2000, 2002; SIRGARDO, 2000; SANTA; BARONI, 2014) afirmam que concepção de atividade mediada por instrumentos representa a retomada da ideia marxista clássica de que a especialização das ações, realizadas pelas

\footnotetext{
${ }^{6}$ KOZULIN, A. The concept of activity in soviet psychology - Vygotsky, his disciples and critics. American
} Psychologist, Washington, v.41, n.3, p. 264-274, 1986. 
mãos (como ferramenta), trouxe ao homem a possibilidade do exercício de atividades especificamente humanas. Ao estender o conceito de mediação, partindo do âmbito da interação homem/ambiente por meio de instrumentos, até a esfera do uso de signos, Vigotski atualiza o seu significado e ao mesmo tempo potencializa o seu alcance.

A ideia de mediação (instrumental e simbólica) é intrinsecamente ligada à origem histórico-cultural das funções psicológicas superiores, que não possuem somente uma origem natural, mas acima de tudo uma história social (RIVIÈRE, 1985, p. 42). Em última análise, para Vigotski o pensamento psicológico de cada indivíduo é parte e resultado da evolução geral da humanidade. Todavia, "esse desenvolvimento não se dá de forma isolada, mas pressupõe diacronicamente todo o caminho precedente da história humana e sincronicamente a participação do indivíduo na vida da sociedade" (MANACORDA, 1992, p. 324).

\subsection{A Teoria da Atividade}

Embora se tenha estabelecido que as pesquisas e escritos de Vigotski tenham marcado a origem da Teoria da Atividade (TA), não é na obra desse pesquisador que a atividade tem importância conceitual significativa. A ele coube a construção das bases da teoria histórico-cultural de uma psicologia comprometida com os problemas reais de seus concidadãos (ARAÚJO, 2013), além da formação da primeira leva de pesquisadores que deram continuidade a essa empreitada, dentre os quais Aleksey Leontiev, fundamental no desenvolvimento e sistematização da Teoria da Atividade.

Emprestado da filosofia - onde foi introduzido para superar a oposição cartesiana entre sujeito e objeto (LEKTORSKY, 2009) - o conceito de atividade assumiu com Leontiev o papel tanto de princípio geral quanto de mecanismo concreto de mediação e foi definido como "uma unidade não aditiva da vida material, corpórea, do sujeito material” (LEONTIEV, 1977, p. 3).

A atividade de Leontiev é uma "formação sistêmica em movimento interno contínuo" (ENGESTRÖM, 1987) cuja característica essencial é sua orientação a um objeto, 
que constitui seu motivo de existência. Dentro da formação dinâmica que é a atividade, o objeto "perde sua aparente naturalidade e surge como um objeto da experiência coletiva, social" (KOZULIN, 2003, p. 131). Nas palavras de Leontiev:

\begin{abstract}
É na atividade que se dá a transição ou 'tradução' do objeto refletido em imagem subjetiva, em ideal; ao mesmo tempo, é também na atividade que se obtém a transição do ideal para os resultados objetivos da atividade, seus produtos, para o material. Vista dessa forma, a atividade é um processo de tráfego intermediário entre polos opostos, sujeito e objeto $(1977$, p. 3).
\end{abstract}

Outro aspecto relevante no arcabouço criado por Leontiev é sua concepção de que uma atividade se estrutura hierarquicamente em ações, relacionadas a objetivos práticos (metas) da realidade imediata; e em operações, processos rotineiros, normalmente espontâneos e automatizados, destinados a promover ajustes em ações em função de condições que o sujeito encontra ao tentar alcançar uma meta (LEONTIEV, 1978). No nível mais alto dessa estrutura hierárquica existe a própria atividade, orientada a um objeto que sintetiza o motivo, do qual o sujeito geralmente não tem consciência. Na camada imediatamente inferior ocorrem as ações, orientadas a metas conscientes, porém não obviamente relacionadas ao motivo da atividade maior.

Assim, embora uma atividade se concretize em ações, seu significado social não é diretamente derivado de ações individuais. No clássico exemplo da caçada primitiva que Leontiev (1978) apresenta, um membro do grupo de caçadores pode entender que espantar o animal na direção dos companheiros que o abaterão é o resultado esperado de sua participação - na verdade apenas uma ação sob sua responsabilidade que, em si mesma, não satisfaz suas necessidades de alimento ou vestimenta -, inconsciente de que a atividade de que participa é a caçada coletiva, da qual efetivamente resultará a satisfação das necessidades citadas (ENGESTRÖM, 1987).

Ao longo da evolução humana, mais precisamente ao longo do processo de passagem da ordem natural à ordem cultural ${ }^{7}$, a estrutura da atividade coletiva humana foi assumindo cada vez mais a forma mediatizada (DUARTE, 2002). Ou seja, a atividade coletiva

\footnotetext{
${ }^{7}$ Vigotski propõe essa transformação do natural ao cultural não como uma via dual, mas a partir da superação. "As funções biológicas não desaparecem com a emergência das culturais, mas adquirem uma nova forma de existência: elas são incorporadas na história humana." (SIGARDO, 2000, p. 51)
} 
dos primitivos seres humanos, que era indiferenciada, foi se transformando, fazendo surgir uma estrutura complexa na qual a atividade coletiva passou a ser composta de ações individuais diferenciadas em termos da divisão do trabalho.

Para Leontiev (1978), a atividade humana não existe a não ser na forma de ações ou conjunto de ações. Ao utilizar o conceito de atividade, portanto, estamos lidando com uma abstração, que somente pode ser definida do ponto de vista de sua relação com um motivo (material ou ideal), que lhe dá direção. Na prática, a atividade não pode ser diretamente percebida, já que o que se percebe são somente as ações que a compõe. É importante atentar para o fato de que cada tipo de ação pode compor diferentes tipos de atividade e cada atividade pode ser realizada por meio de diferentes ações.

Leontiev dedicou-se, portanto, ao estudo do desenvolvimento histórico da mente considerando-a, como Vigotski, um diferencial evolutivo no momento em que a cultura e a sociedade humanas superavam a evolução puramente biológica (SIGARDO, 2000). Em seus estudos, ele identificou três elementos culturais que tiveram papel diferenciado no desenvolvimento da mente: a linguagem, as ferramentas e a divisão do trabalho (ARAÚJO, 2013). Para Leontiev, como também para Vigotski, a linguagem tem um papel fundamental na constituição da atividade e do próprio sujeito. As ferramentas, por sua vez, tiveram papel de destaque na evolução humana, pois tanto sua estrutura quanto o conhecimento da forma de utilizá-las tiveram implicações sobre a forma de interação do homem com o mundo (RÜCKRIEM, 2009).

Lektorsky (2009) afirma que Leontiev não investigou a atividade como um processo coletivo que pressupõe interação e comunicação entre diferentes participantes, embora ele tenha enfatizado que a atividade devesse ser entendida como uma formação coletiva. Coube a seus discípulos e, sob a inspiração deles, a Engeström, incorporar esses aspectos ao estudo da atividade.

Pesquisador finlandês dedicado aos estudos sobre a aprendizagem em contextos institucionais, Yrjö Engeström elaborou sua teoria da aprendizagem por expansão e a desenvolve ao longo do tempo, de forma cada vez mais intervencionista, buscando promover nas comunidades envolvidas o domínio de ferramentas que thes permitam 
transformar as práticas sociais em que estejam envolvidas (SANNINO; DANIELS; GUTIÉRREZ, 2009).

Engeström propôs a existência de três gerações da TA, desenvolvidas nas seis décadas a partir da morte de Vigotski. A primeira geração descende da concepção vigotskiana de mediação e "representa o modo pelo qual Vigotski juntou os artefatos culturais às ações humanas para dispensar o dualismo indivíduo/social" (DANIELS, 2003, p. 114). O modelo triangular que se vê na Figura 3, elaborado por Engeström, apresenta os aspectos centrais dessa primeira geração da TA, cuja limitação, segundo este pesquisador, se deve ao fato de sua "unidade analítica ter permanecido limitada à esfera do individual" (ENGESTRÖM, 1999), situação que seria superada na segunda geração da TA, sob a inspiração das pesquisas de Leontiev.

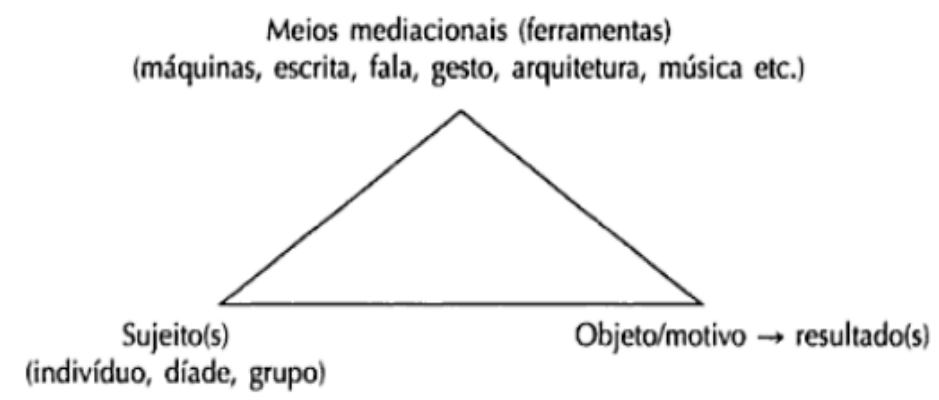

FIGURA 2 Modelo da TA da primeira geração (Engeström, 1999)

Embora Leontiev tenha introduzido a comunidade em seu arcabouço teórico ao discutir o contexto da caçada, "nunca expandiu graficamente o modelo original de Vigotski em um modelo de sistema de atividade coletiva" (ENGESTRÖM, 1999). Isso seria feito por Engeström, para quem as atividades são fenômenos coletivos tanto em relação ao objeto, que é compartilhado pela comunidade, quanto em relação a sua forma, visto que são executadas coletivamente. A Figura 4 exibe a expansão do triângulo de Vigotski feita por Engeström. 


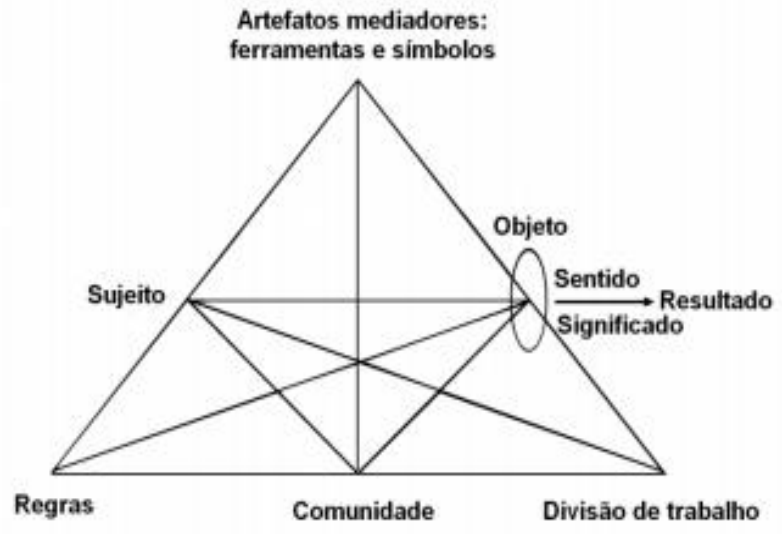

FIGURA 3 Modelo da TA da segunda geração - Sistema de Atividade (Engeström)

Ao analisar o esquema apresentado na Figura 4, Engeström (2002) explica que o subtriângulo superior pode ser visto como 'a ponta do iceberg', representando ações individuais e grupais reunidas em um sistema de atividades coletivo. O objeto é mostrado com a ajuda de uma figura oval, indicando que ações orientadas para o objeto são sempre caracterizadas por ambiguidade, surpresa, interpretação, busca de sentido e potencial para mudanças, de forma explícita ou implícita. Russel (1997, p.4) define um sistema de atividade como "qualquer interação humana continuada dirigida a um objeto, historicamente condicionada, dialeticamente estruturada e mediada por ferramentas". Por meio da análise dos sistemas de atividade em que os seres humanos estão inseridos, é possível, segundo esse autor, analisar a maneira como as ferramentas concretas são usadas para mediar os motivos (direção, trajetória) e o objeto (o foco) de um comportamento ou de uma mudança em um comportamento.

Nessa expansão do modelo original vigotskiano, Engeström representou os elementos sociais/coletivos em um sistema de atividade acrescentando a comunidade e a divisão do trabalho, oriundos do arcabouço de Leontiev, assim como as regras; ao mesmo tempo em que expôs as relações mútuas entre esses elementos. Nessa representação, sujeito, objeto e comunidade mantêm uma "relação de tripla via entre si, e cada uma dessas relações é mediada, sendo ferramentas, regras e divisão do trabalho os mediadores" (KAPTELININ; NARDI, 2006 p. ). Assim, as ferramentas são mediadoras na relação entre o sujeito e o objeto, as regras são mediadoras na relação entre o sujeito e sua comunidade e a divisão do trabalho é a mediadora na relação entre a comunidade e o 
objeto. Para Engeström, o sistema de atividade constitui a unidade analítica da TA (BLACKLER, 2009) e desdobra-se "por longos períodos de tempo sócio-histórico, muitas vezes assumindo a forma de instituições e organizações" (DANIELS, 2003, p. 115).

Finalmente, a terceira geração da TA resulta dos estudos de Engeström para desenvolvimento de "ferramentas conceituais para compreender os diálogos, as múltiplas perspectivas, as vozes e as redes de sistemas de atividade que interagem entre si" (ENGESTRÖM, 1999). No modelo da Figura 5, por exemplo, vê-se o contexto em que o objeto inicial, ainda por desenvolver em dois sistemas de atividade (Objeto 1), é reconstruído de forma mais avançada após uma etapa de ressignificação coletiva (Objeto 2) pelos respectivos sujeitos de cada sistema e, por fim, novamente reconstruído como um objeto compartilhado ou conjuntamente construído (Objeto 3).

Nesse contexto, segundo Daniels (2003, p. 121), há que se considerar que a "ideia das redes de atividade em que as contradições e lutas ocorrem na definição do motivo e do objeto da atividade demanda uma análise de poder e controle nos sistemas de atividade em desenvolvimento".

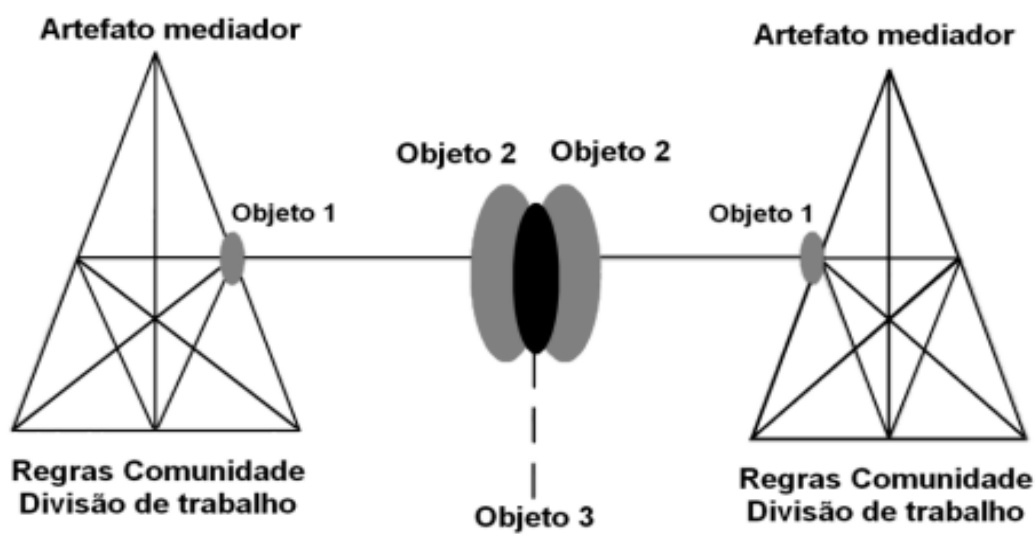

FIGURA 4 Modelo da TA da terceira geração (Engeström)

O sistema de atividade de Engëstron é intrinsecamente permeado por contradições, que regulam a atividade e conferem movimento a ela. Para o autor, as contradições estão entre os princípios básicos mais importantes da TA e ocorrem tanto entre os componentes de um sistema de atividade como na interface de sistemas distintos (JONASSEN, 2000). 
A contradição representa assim uma oportunidade tanto de transformação em um sistema de atividade quanto de aprendizagem para os sujeitos quando eles se tornam conscientes da existência delas e almejam a criação de uma nova forma de atividade (SANNINO; DANIELS; GUTIÉRREZ, 2009). Essa é a essência da teoria da aprendizagem por expansão proposta por Engeström, que enfatiza "a importância das contradições nos sistemas de atividade como a força motriz da mudança e, portanto, do desenvolvimento" (DANIELS, 2003, p. 118).

A aprendizagem dos sujeitos ocorre, portanto, quando um sistema de atividade é reorganizado em uma nova estrutura a partir da análise reflexiva da estrutura anterior e a apropriação (internalização) de instrumentos e modelos para superação das contradições internas. Esse processo de apropriação, na medida em que muda em qualidade as funções psíquicas, estimula a autorreflexão e a reformulação dos modelos na busca de soluções para as contradições. Um novo modelo então é implementado, constituindo o processo de externalização. A cada nova atividade estruturada, novas contradições são incorporadas e um novo ciclo de superação/aprendizagem é implementado, permitindo o movimento e o dinamismo do sistema.

Apoiados sobre a concepção derivada da dialética materialista de Marx, Engeström e Sannino (2011) afirmam que a contradição deve ser analisada como um conceito filosófico fundamental. Como são fenômenos sistêmicos historicamente emergentes, estudos empíricos não têm acesso direto a elas. Devem, pois, ser atingidas através de suas manifestações, também tratadas como construções ou articulações de contradições. Em outras palavras, as contradições não falam por si, tornam-se reconhecidas quando os praticantes articulam e constroem-nas no discurso e ações.

A Teoria da Atividade de Engeström, portanto, pode ser resumida em cinco princípios fundamentais (DANIELS, 2003):

1) Sistema de atividade coletivo: Unidade analítica fundamental que se caracteriza por ser orientada para o objeto, mediada por artefato e existir em uma relação dinâmica ou interativa em rede com outros sistemas de atividade; 
2) Multivocalidade: Múltiplos pontos de vista, tradições e interesses existentes dentro de um sistema de atividade e que são multiplicados nas redes de sistemas de atividades;

3) Historicidade: Contínua transformação dos sistemas de atividade durante longos períodos de tempo, o que justifica a afirmação de Blackler (2009) de que a unidade analítica fundamental para Engeström é o sistema de atividade historicamente localizado;

4) Contradição: Tensão estrutural em um sistema de atividade - ou entre sistemas - que revela potencial para mudança e desenvolvimento;

5) Transformação expansiva: Reconceituação do objeto e do motivo de uma atividade, em direção a outros radicalmente mais amplos, que ocorre em resposta às contradições percebidas pelos sujeitos na situação original e que lhes provocam questionamentos.

A partir do arcabouço teórico apresentado é possível caracterizar a questão da experimentação animal como uma complexa rede de sistemas de atividade na qual cada sujeito envolvido representa uma voz na controvérsia. Buscamos, então, compreender esse fenômeno analisando as unidades e as relações que o compõem por meio da narrativa dos sujeitos. Nos interessa saber quais os elementos estruturais das atividades constituintes da rede de sistemas, como elas se relacionam e, principalmente, quais as contradições mais evidentes dentro e entre os sistemas de atividade, a fim de propor meios pelos quais podemos superá-las.

Com os resultados desta pesquisa esperamos contribuir com subsídios para o desenvolvimento de ações de divulgação científica que representem a questão da experimentação animal de maneira menos dual, enfatizando a dimensão sensível da controvérsia a partir das experiências dos sujeitos envolvidos.

Apresentamos nos capítulos seguintes os objetivos da pesquisa, bem como a estrutura metodológica utilizada nesta investigação. 


\section{OBJETIVOS DA PESQUISA}

Já explicitamos neste trabalho as dificuldades dos museus em desenvolver exposições e ações educativas com temáticas controversas. Tensões ligadas à possibilidade de um cerceamento ideológico por parte do financiador, ou ainda o receio em abordar com o público questões sociocientíficas mais complexas, que podem colocar à prova a legitimidade da ciência, acabam por embaraçar a implantação desse tipo de ação museal.

Além disso, na maior parte dos casos em que essas exposições são implementadas, os pontos fundamentais da controvérsia não são abordados de forma crítica e explícita; os discursos e argumentos expostos não representam todos os sujeitos envolvidos e acabam ecoando majoritariamente a voz da ciência, o que inviabiliza a reflexão e o debate com o público.

Talvez o modo como são consideradas as controvérsias esteja pautado, prioritariamente, na análise da aparência, deixando à margem os elementos essenciais da questão. Esse distanciamento pode, por vezes, impedir os museus de construir o repertório necessário para tratá-las em suas exposições. Como abordar de forma crítica temas multivocais, permeados por tensões historicamente estruturadas sem que haja um aprofundamento ao cerne da questão, compreendendo as relações que unem e distanciam os diferentes pontos de vista?

Não é nossa intenção apresentar neste trabalho uma receita para a elaboração de ações de divulgação científica que discutam as CSC. Contudo, ao analisar dialeticamente a questão da experimentação animal acreditamos contribuir com a apresentação de uma visão que seja menos dual e, ao mesmo tempo, mais focada nas relativizações e tensões que movem os atores envolvidos, fornecendo subsídios para o desenvolvimento de ações que estejam um passo mais próximo da unidade essencial da questão.

Os objetivos descritos no quadro abaixo surgiram de questões que buscamos responder ao longo desta investigação e que nortearam o desenvolvimento deste trabalho. 


\begin{tabular}{|c|c|c|}
\hline & OBJETIVOS & QUESTÕES \\
\hline $\begin{array}{l}\text { G } \\
\text { E } \\
\text { R } \\
\text { A } \\
\text { L }\end{array}$ & $\begin{array}{l}\text { Apontar subsídios para o desenvolvimento de } \\
\text { estratégias de divulgação científica sobre a temática } \\
\text { da Experimentação Animal. }\end{array}$ & $\begin{array}{l}\text { - Que dimensões são relevantes para } \\
\text { apresentar uma visão menos dual da } \\
\text { questão ao público? } \\
\text { - Como fomentar ações que envolvam } \\
\text { o público nas discussões sobre a } \\
\text { experimentação animal? }\end{array}$ \\
\hline & $\begin{array}{l}\text { Compreender a natureza dos argumentos que } \\
\text { sustentam o discurso dos participantes envolvidos na } \\
\text { questão da experimentação animal. }\end{array}$ & $\begin{array}{l}\text { - Sobre que aspectos morais estão } \\
\text { enraizados os argumentos dos } \\
\text { sujeitos envolvidos na questão? } \\
\text { - Como os modos de racionalidade } \\
\text { desses sujeitos se enfrentam? }\end{array}$ \\
\hline $\begin{array}{l}\text { E } \\
\text { S } \\
\text { P } \\
\text { E } \\
\text { C } \\
\text { I } \\
\text { F } \\
\text { I } \\
\text { C }\end{array}$ & $\begin{array}{l}\text { Compreender as contradições que emergem nos e } \\
\text { entre os discursos dos principais sujeitos envolvidos } \\
\text { na questão. }\end{array}$ & $\begin{array}{l}\text { - Que tipo de contradições são } \\
\text { manifestadas no discurso desses } \\
\text { sujeitos? } \\
\text { - Como essas contradições } \\
\text { movimentam os diferentes sistemas } \\
\text { de atividade que compõem a } \\
\text { questão? } \\
\text { - Que tensões e conflitos são inerentes } \\
\text { a essas contradições? }\end{array}$ \\
\hline$S$ & $\begin{array}{l}\text { Apontar subsídios para a elaboração de uma } \\
\text { conferência de consenso e de um survey de } \\
\text { percepção pública acerca da experimentação animal, } \\
\text { a partir da perspectiva dialética. }\end{array}$ & $\begin{array}{l}\text { - De que maneira essas estratégias } \\
\text { podem exercer simultaneamente o } \\
\text { papel de instrumento de coleta de } \\
\text { dados e estratégia de divulgação } \\
\text { científica? } \\
\text { - Que aspectos são mais relevantes na } \\
\text { elaboração de estratégias de } \\
\text { divulgação científica? }\end{array}$ \\
\hline
\end{tabular}




\section{METODOLOGIA DA PESQUISA}

Após apresentar os objetivos da pesquisa, neste capítulo, descrevemos o caminho metodológico percorrido nesta investigação: sua base filosófica, seu contexto, seus participantes, os instrumentos de coleta e geração de dados e os procedimentos de análise de dados.

\subsection{Caracterização da Pesquisa}

Para realizar esta pesquisa, partimos da análise sistemática de um complexo fenômeno social que ocorre em contextos reais de atuação - por exemplo, o trabalho - dos sujeitos investigados para alcançar uma compreensão aprofundada desse fenômeno. Para conduzir a análise, entretanto, fizemos um recorte da realidade a partir da perspectiva fornecida por categorias analíticas adequadas a cada uma das dimensões que compõem essa realidade. Tal estratégia facilitou a descrição e a interpretação dos dados coletados nesses contextos.

O intuito inicial desta investigação foi compreender qual a percepção do público de um museu de ciências acerca da experimentação animal, visando a elaboração de uma exposição sobre a temática. O resultado apresentado adiante nos forneceu um diagnóstico que subsidiou a construção dos demais instrumentos de coleta e etapas analíticas deste estudo.

Contudo, de modo geral, prevaleceu uma abordagem qualitativa aos dados coletados, baseada principalmente em nossa interpretação. Essa postura parte do fato de que a base epistemológica desta pesquisa concebe a produção do conhecimento como necessariamente subjetiva, matizada pelo posicionamento do pesquisador (CROKER, 2009) e centrada no modo como diferentes sujeitos podem apresentar formas distintas de perceber a realidade (HANCOCK; WINDRIDGE; OCKLEFORD, 2007). Pelos motivos expostos, o que apresentamos aqui é apenas uma interpretação possível dos fenômenos observados, não sua explicação definitiva. Preserva-se, portanto, a possibilidade de posteriores aprofundamentos e de novas interpretações. 
Devido a sua natureza interpretativa, este estudo teve por base ideológica uma concepção da realidade socialmente construída (CROKER, 2009). Como a linguagem é elemento constituinte em todos os aspectos da vida social, a construção que se trata aqui é fundamentada na esfera da linguagem em uso, ou seja, no discurso. Nesta dissertação, portanto, a compreensão da complexa controvérsia em torno da experimentação animal e os subsídios fornecidos para sua apropriação por instâncias da divulgação científica foram perseguidos pela análise dos discursos dos sujeitos envolvidos, os quais descrevemos na sessão seguinte.

\subsection{Participantes da pesquisa}

Participam voluntariamente deste estudo os 180 visitantes espontâneos do Museu Biológico - Instituto Butantan - que responderam ao questionário de percepção pública acerca da experimentação animal durante os dias 01, 02, 03 e 09 de maio de 2014, cujo perfil está apresentado no Quadro 3. A maior concentração de respondentes com renda familiar de mais de cinco salários mínimos e, principalmente, a expressividade de sujeitos com elevado nível de escolaridade, seguem um padrão já conhecido entre os públicos museais brasileiros (ALMEIDA, 2005).

\begin{tabular}{|c|c|c|c|}
\hline Parâmetros & Resposta Majoritária & $N(180)$ & Percentual (\%) \\
\hline Gênero & Masculino & 98 & 54 \\
\hline Faixa Etária & $26-35$ Anos & 54 & 30 \\
\hline Nível de Escolaridade & $\begin{array}{l}\text { Ensino Superior (Completo ou } \\
\text { Incompleto) }\end{array}$ & 86 & 48 \\
\hline Renda Familiar & Mais de cinco salários mínimos & 77 & 43 \\
\hline Religião & Cristianismo & 112 & 63 \\
\hline Hábito Alimentar & Não-vegetarianismo & 162 & 90 \\
\hline $\begin{array}{c}\text { Participação e/ou } \\
\text { Contribuição à ONG's }\end{array}$ & Não & 145 & 81 \\
\hline Animais de Estimação & Possui & 133 & 66 \\
\hline
\end{tabular}


Em um segundo momento, foram considerados, como participantes focais e voluntários desta pesquisa, alguns dos sujeitos diretamente envolvidos na questão da experimentação animal no estado de São Paulo, a saber: duas pesquisadores que utilizam animais em suas pesquisas; dois ativistas que desenvolvem trabalhos e iniciativas em favor dos direitos dos animais; um político, reconhecido por desenvolver projetos de leis na temática de proteção animal; um membro do Conselho Nacional de Controle de Experimentação Animal (Concea). Todos esses atores da controvérsia em questão foram entrevistados e puderam ler e validar a transcrição antes do processo de análise documentado no capítulo 5.

Uma síntese das principais atividades e trabalhos desenvolvidos por cada entrevistado está exposta a seguir:

Pesquisadora 1 (P1): possui graduação em Ciências Biológicas, mestrado em Imunologia e doutorado em Ciências (Biologia da Relação Patógeno-Hospedeiro). Desenvolve trabalhos na área de Imunologia, com ênfase em Imunologia Celular, atuando principalmente nos seguintes temas: imunologia da malária, doença de chagas e tuberculose.

Pesquisadora 2 (P2): possui graduação em Ciências Biológicas, mestrado e doutorado em Ciências Biológicas, na modalidade Bioquímica. Desenvolve seus estudos na área de imunologia tumoral, buscando compreender como sinais disparados por tumores influenciam a apresentação de antígenos e a consequente resposta adaptativa antitumoral.

Ativista 1 (A1): possui graduação em Ciências Biológicas e mestrado em alimentos e nutrição. É autor de vários livros e desenvolve diversas atividades nas áreas de direitos animais, bioética, métodos substitutivos ao uso de animais em pesquisa e ensino e nutrição vegetariana.

Ativista 2 (A2): possui graduação, mestrado e doutorado em Letras, com ênfase em Literatura. Trabalha com romances latino-americanos e referenciais teóricos referentes ao existencialismo, ecocrítica, identidade humana e animal e ética animal. Seu grupo de pesquisa investiga principalmente nos campos da libertação e ética animal, veganismo e representação animal na literatura. 
Político (PO): economista e deputado federal pelo Estado de São Paulo, integra a Frente Parlamentar em defesa dos direitos dos animais, desenvolvendo diversos projetos de lei nessa área.

Membro do Concea (MC): membro da Rede Nacional de Métodos Alternativos ao Uso de Animais. Possui graduação em Medicina, especialização em Medicina Farmacêutica, mestrado em Biologia Molecular e doutorado em Ciências. Coordena cursos nas áreas de desenvolvimento de medicamentos sintéticos, biológicos e fitoterápicos.

Queremos destacar que, apesar de todos os entrevistados terem sido extremamente solícitos antes, durante e após as entrevistas, encontramos muita dificuldade em entrevistar pesquisadores e membros de comissões de ética, que se recusavam quando informados sobre o tema da pesquisa. Além disso, somente pesquisadoras retornara aos pedidos de entrevista. Mesmo sem dados suficientes para interpretações sobre a questão do gênero na controvérsia, alguns elementos indicam que existem relações, que devem ser observadas mais de perto.

Esses fatos só reforçam a necessidade de ações que permitam reflexões mais significativas e visem o debate e a superação das atuais controvérsias em torno dessa questão, possibilitando o surgimento de novas tensões e a apropriação de novos instrumentos que permitam um avanço na questão, conforme o referencial teórico apresentado.

\subsection{Instrumentos e procedimentos de coleta e geração de dados}

O primeiro instrumento de coleta utilizado nesta pesquisa foi o questionário de percepção do público do Museu Biológico sobre a temática da experimentação animal. Para sua composição, buscamos elaborar sentenças conflitantes para que o público pudesse refletir mais profundamente sobre as condições que fundamentam sua percepção sobre a temática. Criamos, dessa forma, questões que colocassem em evidência aquelas memórias, sensações e experiências determinantes em sua tomada de decisão. 
O questionário compreendeu parâmetros para o levantamento do perfil do grupo respondente e afirmativas mensuradas por escala de Likert de cinco pontos, variando de 1 - discordo plenamente a 5 - concordo plenamente.

Cabe salientar que, nesse momento do estudo, o mapeamento da percepção em questão não se configurava uma pesquisa de opinião pública acerca da experimentação animal, já que consideramos a percepção sob o olhar da perspectiva histórico-cultural.

Embora, em estudos como os surveys, percepção e opinião possam ser tomadas como sinônimos, neste trabalho assumimos a visão de Vigotski, na qual a percepção humana adulta não é restrita à aparência dos fenômenos apresentados ao indivíduo, constituindo-se em um processo complexo que envolve funções cognitivas superiores tais como a atenção e a memória (CAMPOS, 2013).

Desse modo, quando um indivíduo percebe um objeto da realidade ele o faz a partir dos conteúdos de que dispõe no momento para assim realizar as atividades de seleção, análise e síntese das informações, que se seguem no processo de percepção (ibidem; CUNHA, 2009). Assim, de acordo com Campos (2013), a percepção é um processo de construção ativa na atribuição de significado, ligado portanto às funções de generalização e abstração. O questionário aplicado (Apêndice A), por estar permeado por esses pressupostos, não possui as características essenciais para uma pesquisa de opinião pública ${ }^{8}$, mas os dados obtidos geraram resultados importantes que subsidiaram alguns aspectos das etapas posteriores.

O segundo e principal instrumento de coleta utilizado foram os roteiros das entrevistas semiestruturadas - realizadas entre maio e dezembro de 2015 - cuja análise dos dados respondeu à maior parte das nossas questões de pesquisa (Apêndice B). Os roteiros foram elaborados principalmente a partir dos resultados obtidos com 0

\footnotetext{
${ }^{8}$ De acordo com Freitas e colaboradores (2000), um bom questionário para pesquisa de opinião pública (survey) deve conter:

- perguntas de diferentes categorias (abertas, fechadas, com e sem escala)

- número de perguntas limitado

- questões claras e precisas considerando o nível de informação dos respondentes

- questões que possibilitem uma única interpretação e contenham uma única ideia

- perguntas que respeitem uma sequência, geralmente partindo do mais simples para o mais complexo

- alternativas exaustivas, para as questões fechadas.
} 
questionário aplicado aos visitantes espontâneos do Museu Biológico, que apontaram as principais tensões, os pontos mais críticos da questão para o público. Foram esses resultados que nos fizeram enxergar que a controvérsia da experimentação animal não é um fenômeno dual, formada apenas por dois lados opostos, mas impregnada de relativizações que devem ser compreendidas e consideradas.

A escolha por entrevistas semiestruturadas foi motivada pela flexibilidade, tanto para o entrevistado, quanto para o investigador. Para Triviños (1987), a entrevista semiestruturada tem como característica principal o fato dos questionamentos básicos serem apoiados em teorias e hipóteses que se relacionam ao tema da pesquisa. Dessa forma, o foco principal seria colocado pelo investigador-entrevistador. Ainda de acordo com o autor, essas entrevistas: "favorecem não só a descrição dos fenômenos sociais, mas também sua explicação e a compreensão de sua totalidade, além de manter a presença consciente e atuante do pesquisador no processo de coleta de informações" (TRIVIÑOS, 1987, p. 152).

Uma especificidade desta etapa de coleta está no conhecimento a respeito do tema, por parte de diferentes sujeitos envolvidos. Partindo do pressuposto de que a sociedade também é produtora de conhecimento, consideramos que ambientalistas (representantes de sociedades de proteção animal) são especialistas na questão do uso de animais para pesquisas, pois, ao elaborarem argumentos e sistematizarem práticas contra a experimentação, produzem conhecimento. A apropriação, pela ciência, desses conhecimentos produzidos resulta na busca por novos métodos substitutivos.

Meuser e Nagel (2002) afirmam que as entrevistas com especialistas são uma forma específica de aplicar entrevistas semiestruturadas. Elas são integradas à pesquisa não como um caso individual, único, mas representam um grupo. Sendo assim, o roteiro deve possuir uma função diretiva muito mais forte no que diz respeito à exclusão de tópicos improdutivos, a fim de evitar o surgimento de tópicos irrelevantes e permitir que o especialista discorra sobre seu tema e emita sua opinião sobre a questão.

Documentos obtidos durante a entrevista e após sua realização também ajudaram na coleta de dados que se somariam àqueles coletados por meio da entrevista para posterior análise. As atas das reuniões do Concea nos anos 2013, 2014 e 2015, disponíveis 
no site do MCTI, bem como folhetos institucionais de ONG's de proteção animal entregues por ativistas que participaram da pesquisa, forneceram elementos para a discussão dos resultados levantados.

\subsection{Procedimentos de extração, seleção e análise dos dados}

Para o tratamento dos dados obtidos por meio do questionário de percepção pública acerca da experimentação animal aplicado com os visitantes do Instituto Butantan, fez-se uso do teste não paramétrico Wilcoxon, utilizado para a comparação de amostras pareadas cujos pares são mutuamente independentes.

Após tabulados, os dados foram lançados no programa estatístico JMP ${ }^{\circledR}$ para a realização de cruzamentos entre as respostas de todas as questões do questionário. Foram selecionados os resultados dos cruzamentos que obtiveram maior índice de correlação e para os quais o $p$-valor foi significativo $(p<0,05)$. Ou seja, rejeitamos as correlações que apresentaram mais de $5 \%$ de chance de existirem devido ao acaso, e não sob efeito dos tratamentos.

Os dados das entrevistas e da matéria jornalística foram submetidos à análise textual discursiva, abordagem analítica que transita entre a análise de conteúdo e a análise de discurso. Este processo permite a desconstrução do discurso textual em unidades de significados (MORAES, 2003, MORAES; GALIAZZI, 2006), que, reagrupadas, podem gerar outros conjuntos a partir das interpretações do pesquisador.

A unitarização dos dados transforma aquilo que foi ordenado e sistematizado linearmente em uma composição caótica, permitindo que novas relações entre as unidades sejam evidenciadas por meio da desordem. Segundo Moraes e Galiazzi (2006, p. 118): "neste movimento de interpretação do significado atribuído pelo autor exercita-se a apropriação das palavras de outras vozes para compreender melhor o texto".

Esse processo permite o ordenamento e a articulação de significados semelhantes por meio da categorização. As categorias podem apresentar duas naturezas distintas: definidas a priori, ou seja, estabelecidas previamente a partir do referencial teórico; ou 
emergentes, aquelas que surgem a partir dos dados. É possível ainda que as categorias emergentes complementem as categorias estabelecidas pelo referencial teórico. A criação das categorias é um processo constante de aprimoramento e, segundo Moraes e Galiazzi (2006), definir o núcleo da categoria é essencial para a sustentação da mesma.

Esse processo de análise exige que o pesquisador mergulhe profundamente em seu objeto de pesquisa, reconhecendo-se sujeito e assumindo suas próprias interpretações. Se aproxima, dessa forma, dos pressupostos do método dialético marxista- que fundamentam esta pesquisa - no qual a superação da percepção empírica do fenômeno, por meio da construção de abstrações, conduz à compreensão de uma realidade mais próxima à essência do objeto.

A análise se desloca do empírico para a abstração teórica, que só pode ser alcançada se o pesquisador fizer um movimento intenso de interpretação e produção de argumentos. Este processo todo gera meta-textos analíticos que irão compor os textos interpretativos (MORAES; GALIAZZI, 2006, p. 118).

\subsubsection{A dialética como método de superação da dualidade na questão da experimentação animal}

Segundo Masson (2007), o método não pode servir para fazer com que a realidade se "encaixe" nele como uma camisa de força que permite apenas alguns movimentos controlados; ao contrário, tem o papel de dar sentido e validade explicativa ao objeto da pesquisa. A opção por uma determinada concepção metodológica demonstra a posição do pesquisador diante da realidade e "sua pesquisa revelará uma determinada visão de mundo e os elementos que contribuirão para a legitimação ou transformação do real" (MASSON, 2007, p.113).

Ao olharmos a questão da experimentação animal, imediatamente temos uma representação caótica do todo, que se limita ao contrário de dois lados: contra e a favor. É dessa forma que a percebemos nos aproximamos sem um compromisso analítico do material veiculado na grande mídia. Porém, quando analisamos a questão em suas partes 
nos deparamos com um universo de relações e unidades, relativizações e contradições que a compõem e a tornam muito mais rica.

Acreditamos, portanto, que o método dialético na perspectiva marxista, é o escopo teórico que confere significado à nossa pesquisa, contribuindo para a superação da dualidade da controvérsia da experimentação animal que, ao revelar as tensões e conflitos que entremeiam a questão, nos leva a um novo concreto.

Diversos autores tentaram estabelecer critérios práticos para a realização de uma análise dialética. Não é nossa intenção aqui engessar uma teoria dinâmica, focada no movimento dos fenômenos que compõem a realidade. Contudo, devido à complexidade do fenômeno analisado acreditamos que alguns desses critérios de orientação possam garantir que os aspectos essenciais ao método em questão não escapem de nossa análise. Essas "regras práticas" elencadas por Henri Lefèbvre em seu livro 'Lógica formal, lógica dialética ${ }^{\prime \prime}$, nos auxiliaram na proposição das questões que procuramos responder em nossa investigação visando superar a percepção sensível dessa controvérsia. Em resumo essas regras práticas são:

1) penetrar mais profundo que a simples percepção observável, apreendendo o conjunto das conexões internas do fenômeno, seu movimento e desenvolvimento, bem como seus aspectos contraditórios;

2) analisar o conflito interno das contradições;

3) não se esquecer das relações e interações das unidades que compõem o todo e que o processo de aprofundamento do conhecimento - caminho à essência - é infinito;

4) superar a própria compreensão do fenômeno - rejeitar sua forma, remanejar seu conteúdo.

Pensar dialeticamente a questão da experimentação animal é compreender que os atores envolvidos são sujeitos sociais imersos em um contexto histórico e que são seus modos de pensar, suas experiências e atitudes que transformam e movimentam essa

\footnotetext{
${ }^{9}$ LEFÈBVRE, H. Lógica Formal, Lógica Dialética. Rio de Janeiro: Civilização Brasileira, 1975.
} 
questão. Por isso, são os atores que constituem essa controvérsia, o foco principal desta pesquisa. Meyer (2015) afirma que a análise de uma controvérsia sociocientífica baseia-se geralmente na descrição profunda dos vários atores envolvidos. Buscamos, entretanto, extrapolar o processo descritivo observando as unidades e conexões internas deste fenômeno a partir do discurso desses sujeitos.

Devido à impossibilidade de reduzir a complexidade da controvérsia e, ao mesmo tempo, incluir todos os aspectos relevantes para alcançar uma representação completa e apropriada, nos concentramos em duas dimensões que compõem a questão da experimentação animal e que foram evidenciadas no discurso dos sujeitos: as mediações referentes aos argumentos utilizados pelos atores envolvidos e as contradições - bem como suas tensões internas - emergentes desse discurso.

Sabemos que, em uma controvérsia, os integrantes defendem suas concepções de mundo. Ou seja, seus argumentos estão enraizados em sistemas de valores, em aspectos morais relevantes. Nos interessou saber, então, qual a natureza dos argumentos utilizados pelos sujeitos envolvidos na questão, e ainda que conjunto de códigos e valores sustenta esses argumentos. Para tanto, buscamos subsídios nas teorias morais da ética normativa, campo que se ocupa com "quais espécies de coisas são boas", "quais atos são bons" e “quais são as relações entre o certo e o bom" (JAMIESON, 2010, P. 125).

A análise da natureza do argumento não está relacionada aqui aos trabalhos da área que visam a argumentação em si, sua estrutura, mas um olhar para o teor do que é dito nessas argumentações. As categorias criadas para essa análise partem da leitura das Teorias Morais, campo inserido na Ética Normativa. No entanto, durante a análise dos materiais, uma nova categoria emergiu no processo. As categorias propostas agrupam os argumentos que estão centrados no (a):

Consequência - nesta categoria, encontram-se os aspectos que trazem a questão da importância do argumento de acordo com as consequências que ele gera, tanto negativamente quanto positivamente. No entanto, esse juízo de valor depende de quem está fazendo o uso dele, pois uma consequência ruim para um pode ser apenas necessária para se atingir um objetivo maior. Nas Teorias Morais, essa categoria se aproxima da Teoria Consequencialista, na qual um fenômeno deve ser avaliado segundo suas consequências e 
seu sucesso depende da quantidade de bem-estar geral que ele consegue gerar ao final do processo (JAMIESON, 2010).

Sujeito - os argumentos enquadrados nessa categoria se justificam trazendo o caráter daquele que desenvolve a ação em questão. Quando o argumento está sendo construído, importa quem o está executando e como essa pessoa age segundo sua formação moral. Quando usada positivamente, as qualidades do ator são destacadas em detrimento à ação ou suas consequências em si. No caso contrário, seus defeitos são realçados. A Ética da Virtude é o campo da Teoria da Moral que se aproxima dessa categoria. Um eticista da moral sempre busca explicar um fenômeno de acordo com o caráter daquele que o desencadeou (JAMIESON, 2010).

Motivo - inspirada na filosofia de Kant, essa categoria indica os argumentos que realçam as motivações para executar a ação. Contudo, essas motivações possuem uma natureza específica. Como Kant postulou, essas motivações seriam de natureza imperativa categórica, ou seja, elas estão pautadas em três máximas: na lei universal, no fim em si mesmo e na autonomia do motivo (JAMIESON, 2010).

Aspecto científico - essa categoria emergente é a única que não possui inspiração nas Teorias da Moral. Estão inseridos nesta categoria os argumentos pautados em dados científicos de caráter biológico trazidos pelos sujeitos analisados. Nesta classe, não se considera a validade científica ou a atualidade dos dados suscitados, mas sim a presença deles na argumentação.

Outra forma de análise adotada a respeito das categorias seria se o argumento está embasando o posicionamento de quem o declara ou se ele serve para caracterizar o posicionamento do outro sujeito envolvido no embate da experimentação animal. Dessa forma, é possível caracterizar qual a natureza de argumento dominante, tanto para defender seu ponto de vista, quanto àquele caracterizador do discurso do outro.

É importante ressaltar que para esta análise foi criada uma simetria artificial dos argumentos. Isto é, eles foram colocados em um mesmo nível para torná-los visíveis, construindo entre eles uma equivalência (MEADEL, 2015). Contudo, quando colocamos atores de uma controvérsia no mesmo nível para estudar seus discursos, não podemos 
esquecer que nem todos possuem os mesmos recursos para aplicá-los no espaço público. Existem relações de poder inerentes à questão que são essenciais e que devem ser consideradas.

A análise das contradições manifestadas no discurso dos sujeitos que compõem a questão foi realizada à luz dos elementos oriundos da Teoria da Atividade (discutidos no capítulo 4). Procuramos caracterizar as atividades dos sujeitos bem como localizar as contradições dentro e entre os sistemas de atividade, apontando as tensões e conflitos internos inerentes a elas.

A categorização dos dados foi discutida entre os membros do grupo de pesquisa CHOICES $^{10}$, e as categorias, a partir dessas discussões, foram sendo reformuladas até o quadro que será apresentado na seção seguinte.

Cabe afirmar que não foram realizadas nesta pesquisa duas análises distintas para a compreensão do mesmo fenômeno, mas buscamos o aprofundamento - de forma dialética - em duas dimensões que compõem essa realidade, embora existam muitas outras.

\footnotetext{
${ }^{10}$ Culture and Historicity in Out of school Innovations for Communicationand Education in Science
} 


\section{AS CONTRADIÇÕES NA QUESTÃO DA EXPERIMENTAÇÃO ANIMAL: UM APROFUNDAMENTO À ESSÊNCIA}

Este capítulo é dividido em duas seções. Na primeira seção, apresentamos o resultado da análise dos dados obtidos por meio do questionário aplicado junto aos visitantes do instituto Butantan, após a realização do cruzamento entre as sentenças. Buscamos compreender os fatores que poderiam influenciar as respostas do público, a quais relativizações essas respostas estariam conectadas e, por fim, comparar com resultados das pesquisas internacionais apontadas no capítulo 2. No fim da primeira seção é apresentada uma proposta de interpretação para os resultados das análises, bem como os aspectos que subsidiaram as análises relatadas nas seções seguintes.

$\mathrm{Na}$ segunda seção, apresentamos o resultado da análise de extratos das transcrições das entrevistas com os sujeitos envolvidos na questão da experimentação animal, bem como da matéria jornalística. Esse conteúdo, por sua vez, foi analisado sob dois aspectos: para extração de categorias emergentes relacionadas aos elementos oriundos do referencial teórico da Teoria da Atividade (discutido no capítulo 3) - sistema de atividade e contradição; e à luz de categorias pré-definidas procedentes da Teoria da Moral - abordada no capítulo 4 - visando a compreensão dos aspectos morais que sustentam os argumentos extraídos dos discursos dos sujeitos.

As conclusões apresentadas na primeira seção são assimiladas às conclusões apresentadas na segunda seção para composição de um quadro abrangente - incluindo as perspectivas social, histórica e cultural - dos processos de apropriação dos elementos constituintes da controvérsia em questão, o que permite satisfazer o segundo e terceiro objetivos da pesquisa.

\subsection{Questionário de percepção pública acerca da Experimentação Animal}

O questionário de percepção pública (Apêndice A) apresentou 16 questões, mas para a discussão aqui proposta, focaremos naquelas cujas análises subsidiaram a segunda etapa da pesquisa. 
Foi, portanto, desenvolvido um cruzamento analítico entre os resultados da sentença "Cientistas devem usar animais em testes médicos para salvar vidas humanas", que representa a colocação mais geral acerca da aceitação à experimentação animal, e as variáveis gênero, posse de animais de estimação e grupo animal utilizado na pesquisa (cães e moscas). Em nossa análise, esses elementos constituem os parâmetros nos quais identificamos maiores índices de correlação. Ou seja, há maiores chances que as variáveis em questão influenciem umas às outras e não se correlacionem por mero acaso.

\section{Gênero}

Ao correlacionar a variável "sexo" com a variável "Cientistas devem usar animais em testes médicos para salvar vidas humanas" verificou-se um nível de concordância maior por parte dos homens em relação às mulheres (Figura 6). Essa diferença no gênero é equivalente à encontrada em pesquisas aplicadas na Europa e explicada por alguns autores devido ao fato de homens e mulheres possuírem padrões sociais diferentes, tendo as mulheres relações mais empáticas e cuidadosas, que se estendem aos animais (HERZOG; BETCHART; PITTMAN, 1991; PIFER; SHIMIZU; PIFER, 1994). Outros autores explicam que as mulheres possuem experiência social de opressão e dominação masculina e, por isso, tendem a defender os direitos dos animais e concordar menos com a experimentação animal (DONOVAN, 1990; PEEK; BELL; DUNHAM, 1996).

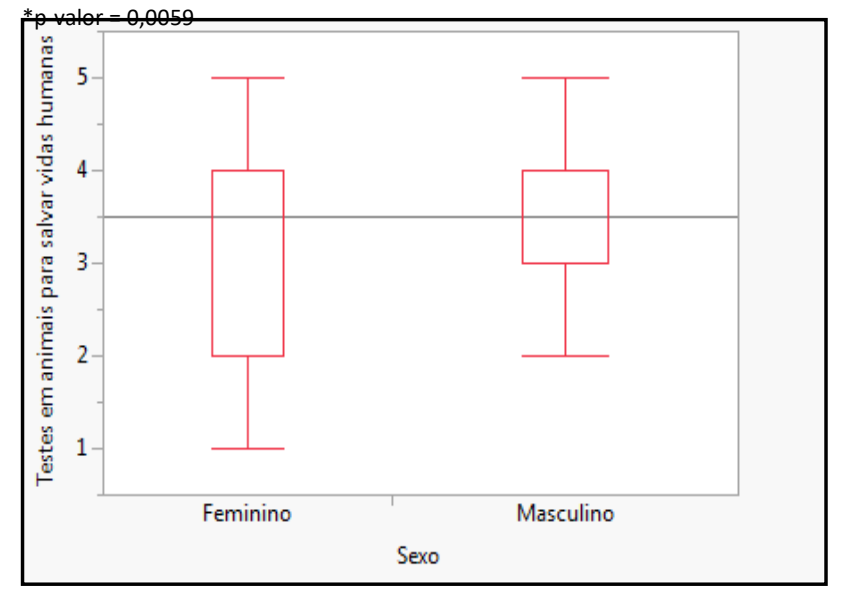

FIGURA 5. Teste de Wicoxon aplicado às variáveis "sexo" e "testes em animais para salvar vidas humanas" 
Saber que homens e mulheres reagem de forma diferente a essa questão, e que essa diferença está relacionada a questões ainda mais intrínsecas e complexas, pode nos ajudar a formular ações que aprofundem e abordem conflitos que vão além da experimentação animal, e que englobam também aspectos socioculturais relevantes.

\section{Animais de Estimação}

Em nossa análise, ter um animal de estimação se mostrou como um fator negativo à aceitação de experimentos com animais para salvar vidas humanas (Figura 7). Segundo Hagelin (2003), pessoas que possuem animais de estimação tendem a ser mais preocupados com o bem-estar dos animais em geral e mais envolvidos com questões de direitos dos animais do que aquelas que não possuem.

Foi possível observar também que a maioria dos respondentes não aceita a experimentação em animais que são os "pets" mais comuns, como cães e gatos. Mas o nível de aceitação com outros grupos animais como serpentes, moscas e carrapatos é de $65 \%, 73 \%$ e $79 \%$, respectivamente. Isso pode indicar que o público ainda não tem construído em si um critério ou argumentos sólidos que sustentem sua percepção, e que em paralelo é influenciado pela aparência e proximidade afetiva com os animais. Este é um fator que corrobora ainda mais a necessidade de elaboramos ações e atividades que, a partir de questões e controvérsias, provoquem o público a refletir e discutir com mais profundidade o tema e possibilitem a construção de argumentos mais consistentes.

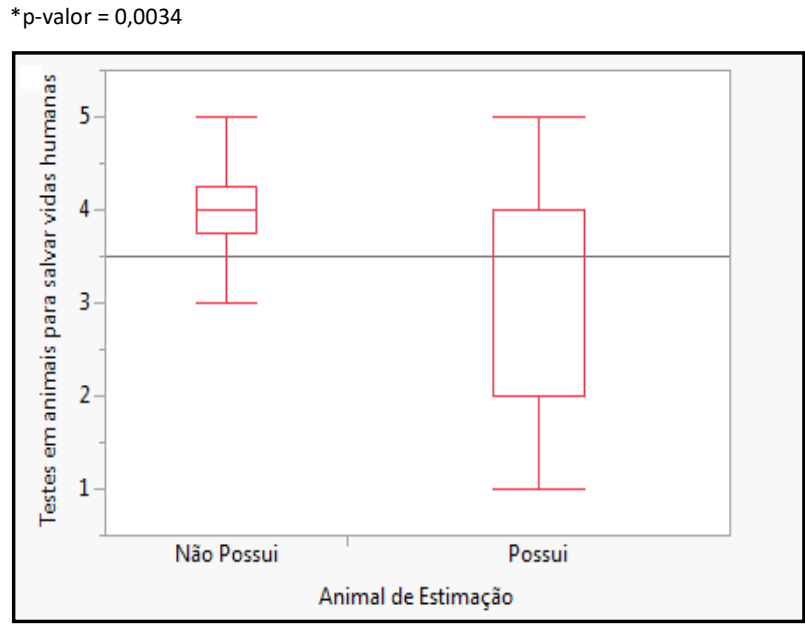

FIGURA 6. Teste de Wicoxon aplicado às variáveis "animais de estimação" e "testes em animais para salvar vidas humanas" 


\section{Grupo animal utilizado na pesquisa: "Testes em Cães" e "Testes em Moscas"}

Para analisar se a proximidade evolutiva constitui um fator de influência na decisão do público em aceitar ou não as pesquisas com animais, cruzamos os resultados da questão: "O quanto você concorda com o uso de CADA UM desses animais em experimentos? ", isolando dois grupos bem distintos: cães (Figura 8) e moscas (Figura 9) com os resultados da sentença "Cientistas devem usar animais em testes médicos para salvar vidas humanas".

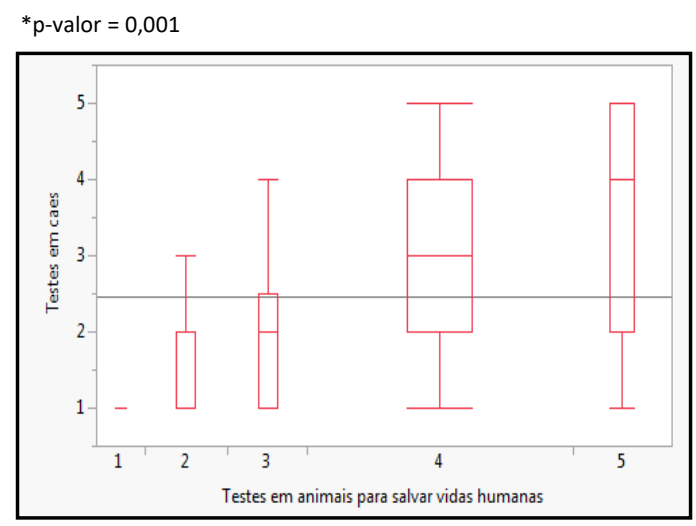

FIGURA 7. Teste de Wicoxon aplicado às variáveis "testes em cães" e "testes em animais para salvar vidas humanas"

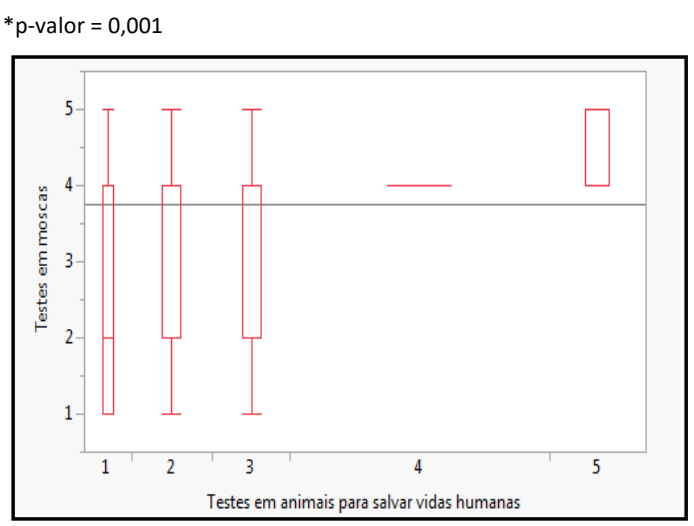

FIGURA 8. Teste de Wicoxon aplicado às variáveis "testes em moscas" e "testes em animais para salvar vidas humanas"

Como pode ser observado nas figuras acima, houve maior distribuição das respostas relacionadas aos testes em cães, enquanto as respostas para os testes em moscas foram mais enfáticas: $100 \%$ dos indivíduos que concordam plenamente com a experimentação animal para salvar vidas humanas concordam em algum grau com os testes em moscas. Alguns estudos apontam que o uso de animais como cães, gatos e primatas não humanos em testes possuem um nível extremamente menor de aceitação que experimentos realizados em artrópodes, répteis e roedores (ROTEN, 2013).

Todavia, o que notamos é que essa diferença de aceitação dos experimentos em cães e moscas está mais associada ao fato dos cães se constituírem como um dos principais grupos de animais utilizados como "pet", e não propriamente com a proximidade entre as 
linhagens evolutivas de cães e seres humanos, já que o nível de aceitação a pesquisas com macacos, por exemplo, foi de $51 \%$, enquanto com cães foi de apenas $30 \%$.

Outras correlações precisam ser estabelecidas, principalmente no que tange às questões sobre o uso de animais em testes para benefício humano e os padrões sociodemográficos do público - como educação e engajamento com a ciência. Assim, compreendemos que os dados analisados nesta investigação oferecem apenas uma visão diagnóstica dessa questão, visto que são necessários novos cruzamentos entre as informações e, ainda, o desenvolvimento da pesquisa para um público mais amplo.

Ainda que de forma preliminar, os dados indicam a existência de alguns fatores que influenciam a percepção do público sobre o uso de animais em experimentos. É possível observar também que os resultados obtidos no contexto desse estudo apresentam certa semelhança com algumas pesquisas realizadas na Europa (HAGELIN, 2003; ROTEN, 2008, 2013; D'ACAMPORA et. al, 2009;), mas somente pesquisas mais detalhadas e com maior número de respondentes poderão delinear as diferenças e semelhanças com esses estudos.

A partir das discussões acima, o aprofundamento nas dimensões que compõem a questão da experimentação animal se faz necessário na tentativa de melhorar nossa compreensão da relação entre ciência e sociedade, já que o uso de animais em pesquisas é um ponto chave na relação do público com a ciência. Essa análise fornecerá subsídios para o desenvolvimento de ações educativas que incentivem maior participação popular nas questões da ciência e tecnologia, seja no âmbito não formal ou da divulgação científica.

Os resultados, ainda que diagnósticos, permitiram o mapeamento de algumas tensões e relativizações da questão. Esses elementos subsidiaram a elaboração das perguntas das entrevistas semiestruturadas, já que procuramos colocar os participantes diante dessas tensões. 


\subsection{A natureza dos argumentos na controvérsia da experimentação animal}

Para esta análise, foram selecionadas as entrevistas semiestruturadas com os sujeitos que participam diretamente da questão da experimentação animal pesquisadores, membros de sociedades de proteção animal, político e membro do Conselho Nacional de Controle de Experimentação Animal.

\subsubsection{Pesquisadores}

Durante a análise dos discursos dos pesquisadores, foram identificadas 41 argumentações a respeito da experimentação animal, ou seja, as unidades que foram analisadas: 27 para embasar a própria atividade de pesquisa e 14 caracterizando o trabalho de outro sujeito envolvido na questão.

A tipologia da argumentação mais utilizada a seu favor, enquanto pesquisadores da área da imunologia, foi a centrada na consequência, citada catorze vezes. Esse era um resultado esperado, já que é comum que cientistas justifiquem o uso de animais evidenciando os numerosos benefícios à vida humana alcançados por meio da experimentação.

\footnotetext{
Isso é em prol da saúde humana. Eu trabalhei no hospital do câncer, muitos anos, e lá era muito duro, assim... Era no hospital e você via aquela criancinha com hepatocarcinoma, amarela, aquela barriga daquele tamanho. Era um tal de subir gente chorando porque encontrava alguém pelo corredor. É muito duro, assim, é uma doença que acho que é muito dura. E essa questão de, né... se vai largar ou se vai fazer alguma coisa a respeito? Eu por enquanto acho que a gente devia fazer alguma coisa a respeito e se eu puder contribuir com isso eu vou ficar, vou achar que é uma coisa boa. (P2)
}

Os argumentos científicos/biológicos foram citados seis vezes para embasar o trabalho dos pesquisadores. É interessante expor que esse tipo de argumentação também foi utilizado para revelar as limitações que a experimentação animal apresenta no próprio fazer científico, como é possível observar neste trecho da entrevista com a pesquisadora 2: 
Eu acho que a tendência é que a gente vá cada vez mais pro paciente e menos no camundongo. Por que? Porque tem várias limitações e cada coisa tem suas limitações. Então assim, tem uma limitação da parte do animal, que o animal não é pessoa e nem tudo dá pra extrapolar. (P2)

Chama atenção o aparecimento de argumentos centrados no motivo, que apareceram quatro vezes durante o discurso da pesquisadora 1. Ela sustenta seu argumento em uma lei universal de que um organismo não sobrevive sem se utilizar de outro ser vivo, criando assim, um imperativo categórico, como pode ser observado abaixo:

É, se a gente tem direito à vida dos animais? É, eu não sei se isso chama direito pra mim, mas eu acho que todos os seres vivos, biológicos, de alguma maneira utilizam outros seres biológicos pra sua sobrevivência, né. Eu acho que a gente vai incluir aqui praticamente a vida toda. Eu não sei se tem algum ser biológico que não utiliza outro ser para o seu bem-estar, vai. Então isso é só mais uma maneira de fazer isso. Eu acho que isso é uma constante e a gente dificilmente vive sem essa constante. (P1)

Os argumentos que são sustentados pelas características do sujeito apareceram por três vezes durante o discurso dos pesquisadores. Eles também foram utilizados para colocar em xeque a postura de outros sujeitos envolvidos, como os membros de sociedades protetoras dos animais e políticos, como evidenciam os trechos abaixo:

Primeiro, eu interpreto que eles estão indo um pouco pro cachorro. Então quando se fala pro camundongo, eu já aposto que muita gente vai com a vassoura matar o camundongo dentro de casa, então o negócio já ia perder um pouco. E se colocar drosófila, eu acho que, o pessoal pega raquetinha lá e fica e não quer nem saber. (P1)

Assim, acho que nesse ponto essa questão de bom senso é importante. Eu não vejo muito no nosso Congresso muita gente com bom senso. (P2)

É interessante ressaltar que a pesquisadora 1 trouxe essas argumentações relacionadas ao ativista na busca por uma coerência entre suas atitudes e seu trabalho. Contudo, a pesquisadora 2 traz em seu discurso o mesmo tipo de argumentação para questionar o bom senso dos pesquisadores em relação ao uso de animais para pesquisas 
que não fornecem contribuições relevantes para a área, ou em casos em que já existem métodos alternativos validados.

Acho que tem algumas coisas muito importantes, assim, quando que um pesquisador vai aprovar um estudo que acha que não vai dar em grandes coisas? Né? Vai fazer porque o cara tem que fazer um mestrado? Entendeu? Acho que esse tipo de coisa tem que começar a ser muito questionada. Veja, acho que nada que é radical é bom.

"Não, mas vamos fazer isso no bicho que é mais barato." Entendeu, pera aí. Não é que tem que pagar, se você pode fazer isso em cultura. " ah, mas é caro". Eu falei: "Mas isso não é problema de..." é problema seu, assim, entendeu?! Não tem essa. Nesse caso, assim, se não tem outro jeito, ok. Mas se você pode, desculpa, mas não. Não vale. Aí você tá sendo antiético, né. É, não tem muita conversa. (P2)

A natureza dos argumentos apresentados pelas duas pesquisadoras está explícita de maneira resumida no quadro abaixo (Quadro 4).

\begin{tabular}{c|c|c}
\hline PESQUISADORES & $\begin{array}{c}\text { A respeito do seu } \\
\text { trabalho }\end{array}$ & $\begin{array}{c}\text { A respeito do } \\
\text { trabalho do outro }\end{array}$ \\
\hline Natureza do Argumento & \multicolumn{2}{|c}{ Frequência } \\
\hline Consequência & 14 & 3 \\
\hline Sujeito & 3 & 7 \\
\hline Motivo & 4 & 1 \\
\hline Aspecto Científico & 6 & 3 \\
\hline
\end{tabular}

QUADRO 4 Natureza dos Argumentos - Pesquisadores

\subsubsection{Membros de sociedades protetora de animais}

Os membros de sociedades de proteção animal entrevistados fizeram uso de cinquenta argumentos para definir seu posicionamento a respeito da experimentação animal: vinte e nove embasando o seu ponto de vista e vinte e um desconstruindo os argumentos dos demais sujeitos (Quadro 2). Ao todo foram analisadas 47 unidades argumentativas. Seu principal argumento, enquanto ativista, está centrado no motivo. Os ativistas utilizaram principalmente o imperativo categórico do fim em si mesmo para 
explicar porque não se deve fazer experimentação animal. Ou seja, o valor intrínseco do animal é colocado como prioridade. A máxima de que ele é sujeito e deve ter seus direitos garantidos contrapõe a forma utilitarista como a ciência o trata.

Mas você está ignorando o indivíduo, né, seu interesse individual. Então você não poderia fazer isso, matar uma pessoa, nem que fosse matar uma pessoa $p$ salvar milhares, você não pode fazer isso com seres humanos, por que você poderia fazer isso com animais? Não pode. Não deveria poder. Isso é um argumento utilitarista. (A2)

O consequencialismo também foi um argumento usado por esses sujeitos para sustentar o fim do uso de animais não humanos em experimentos. A ativista 1 recorreu a esse tipo de argumento quatro vezes e duas das falas estão representadas abaixo:

Existe mesmo um jeito de entender a experimentação animal assim, né. Os produtos são testados em animais e aí uma substância que poderia ser nociva, causar alergia e ser nociva para o corpo humano pode não ser porque foi testada em um animal que tem uma compatibilidade de pele semelhante a nossa, né, coelho, por exemplo. Mas não existe uma garantia de que os produtos testados em animais vão ser inofensivos nos humanos. E a gente já teve algumas evidências a respeito disso, né. Tem um medicamento que foi usado na década de 50 , se eu não me engano, que era pra que as mulheres que estavam grávidas não sentissem enjoo, chamava talidomida. E causou deformação nos fetos. Houve uma geração de crianças que nasceram comprometidas e as substâncias tinham sido testadas em animais. Então sim, essa é uma visão importante. (A1)

Então assim, quando as pessoas, né, "ai, eu vou deixar isso, porque isso não faz bem pra minha saúde, então eu vou comprar um produto não testado em animal", mas vai comer carne, vai usar casaco de couro, vai explorar os animais de outras formas. Então acho que é gastar energia com uma estratégia vã. (A1)

Em relação ao embasamento do trabalho por dados científicos, os ativistas argumentaram cinco vezes. Mas, enquanto a ativista 1 utilizou dados biológicos com cautela em seu discurso, o ativista 2 é reconhecido por sua participação em palestras e debates onde refuta cientificamente os argumentos dos pesquisadores. Talvez por ser biólogo, tenha argumentado utilizando esses elementos com mais frequência e propriedade. 
Agora se você falar que "não, se eu inocular tal coisa no feijão, eu vou conseguir derivar esse dado pra um shampoo que não arde nos olhos de criança", e eu não peguei esse exemplo aleatoriamente, ele existe mesmo, alguém vai questionar "meu, o que feijão tem a ver com olho de criança? " Mas estatisticamente tem mais relação entre o olho de criança e a germinação desse feijão do que o olho da criança e olho de um coelho albino. (A2)

A gente pode. Porque essa etapa que a gente utiliza animais cientificamente não assegura a segurança dos seres humanos depois. (A2)

Os defensores dos direitos animais - assim como os pesquisadores - parecem saber que as motivações dos cientistas com a experimentação animal são os benefícios, principalmente à saúde humana, decorrentes da prática. No entanto, para eles o sofrimento animal não vale os benefícios científicos e, dessa forma, não é um argumento válido. Quando procuram explicar por que os cientistas realizam experimentos com animais, fica claro em seu discurso que se trata de algo relacionado ao caráter dos mesmos, já que a argumentação baseada no indivíduo apareceu quinze vezes com o objetivo de desconstruir o discurso dos pesquisadores.

As pessoas, a sociedade não tem ideia do nível de crueldade que envolve experimentação animal. Aí eu fico pensando assim "como pode ser, né, somos frios? O pesquisador, as pessoas se tornaram indiferentes ao sofrimento animal?' Por mais que se tente evitar eles sofrem. (A1)

[...] das pessoas que estão lá, das pessoas que são de outras áreas, de áreas biológicas, que estão tão acostumadas a usar os animais, que talvez tenham perdido um pouco, sabe, essa identificação com eles, porque somos animais que nem eles. É isso que eu penso. (A1)

As frequências dos argumentos apresentados pelos ativistas estão apresentadas no quadro abaixo (Quadro 5). 


\begin{tabular}{c|c|c}
\hline MEMBROS SPA & $\begin{array}{c}\text { A respeito do seu } \\
\text { trabalho }\end{array}$ & $\begin{array}{c}\text { A respeito do } \\
\text { trabalho do outro }\end{array}$ \\
\hline Natureza do Argumento & \multicolumn{2}{|c}{ Frequência } \\
\hline Consequência & 4 & 6 \\
\hline Sujeito & 1 & 15 \\
\hline Motivo & 16 & 0 \\
\hline Aspecto Científico & 5 & 0 \\
\hline
\end{tabular}

Quadro 5. Natureza dos Argumentos - Membros SPA

\subsubsection{Político}

O político entrevistado foi o sujeito que menos apresentou argumentos em seu discurso, que apresentou 15 unidades de análise. Ao todo foram identificados oito trechos de argumentação (Quadro 6), a maioria focando as consequências, boas ou ruins, do seu trabalho, como exposto nos trechos abaixo:

Acho que vai ser um ganho moral pro Brasil, na questão do respeito aos animais e vai ser ganho econômico, financeiro, na questão mercadológica, que a gente vai poder colocar os produtos do Brasil na comunidade europeia. (PO)

Os animais são utilizados desnecessariamente. Se a gente puder aplicar testes alternativos pelo menos aqueles que diminuem o número de animais, já vai ser um ganho de vidas que a gente vai estar economizando. (PO)

É possível observar em seu discurso a importância do animal como sujeito que deve possuir direitos garantidos pela legislação brasileira, por meio do uso de argumentos centrados nas motivações, a partir do imperativo categórico do fim em si mesmo.

A natureza jurídica do animal, hoje ele é considerado uma coisa, um objeto, e não um sujeito que tem direitos. Mas ele sente dor, sofre, tristeza, alegria, tudo. Então ele merece ser tratado como um sujeito que tem direitos, não obrigações, mas direitos ele deveria ter. (PO)

Todo animal que tem vida, deveria ter uma proteção. Isso é indiscutível. Quem disse que eles não têm sentimento, ou que não tem dor. (PO) 
Todavia, frente às dificuldades em fazer política no Brasil, ele muitas vezes se vê cercado diante dos interesses dos mais diversos setores - econômico, científico, cultural e acaba, de forma consequencialista, se contentando com a garantia do bem-estar animal na pesquisa, em detrimento dos direitos animais.

Eu acho que se a gente conseguir chegar na abolição total é melhor, mas tem casos que a gente não consegue. Ou não consegue por causa da questão cultural ou da questão científica. Então onde não der, o quanto a gente conseguir aplicar mais o bem-estar e diminuir o número de vidas utilizadas é bom, mas onde a gente puder ter a abolição total, a gente deve aplicar a abolição total. (PO)

Esse fato, como veremos mais adiante, configura uma tensão na forma do sujeito atuar na realidade. Ou seja, em sua atividade. Já que, em seu pensamento, o animal deveria gozar do direito superior e fundamental à vida - como os seres humanos -, enquanto que suas ações caminham em direção ao bem-estar animal.

As frequências dos argumentos apresentados pelo político estão apresentadas no quadro abaixo (Quadro 6).

\begin{tabular}{c|c|c}
\hline Político & $\begin{array}{c}\text { A respeito do seu } \\
\text { trabalho }\end{array}$ & $\begin{array}{c}\text { A respeito do } \\
\text { trabalho do outro }\end{array}$ \\
\hline Natureza do Argumento & \multicolumn{2}{|c}{ Frequência } \\
\hline Consequência & 3 & 1 \\
\hline Sujeito & 0 & 1 \\
\hline Motivo & 2 & 0 \\
\hline Aspecto Científico & 1 & 0 \\
\hline
\end{tabular}

QUADRO 6 Natureza dos Argumentos - Político

\subsubsection{Membro do Conselho Nacional de Controle de Experimentação Animal}

O membro do Concea, órgão que regula a experimentação animal no Brasil, argumentou nove vezes, todas para justificar o seu trabalho, não existindo assim nenhum argumento que descaracterize o trabalho de outro membro envolvido na questão (Quadro 7). 
Como também já era esperado, a maior parte de sua argumentação está centrada nas consequências do seu trabalho. Todavia, também está presente em seu discurso, assim como no discurso dos pesquisadores, as limitações da prática da experimentação e a necessidade de superá-las. O entrevistado enfatiza ainda a relativização da controvérsia, o que mostra que a questão da dualidade já está sendo reconhecida e refletida pelos sujeitos.

Os testes representam um estágio da tecnologia, da humanidade. A humanidade vai superar esse estágio, pra outro. Mas naquele momento era o que tinha. Por que assim, aí está a questão, você quer mais gente com o bracinho assim ${ }^{11}$ Então tem que fazer em animal. Ou então, bom, arrumamos outra coisa. Nesses 40 anos, dos anos 1960 aos anos 2000, 2010, era o que tinha. Agora, muito em breve haverá outras coisas. (MC)

O erro aí tá no tudo ou nada, tá no preto e branco. O mundo é mais cinza do que preto e branco. Em alguns casos dá errado, mas nunca mais teve outra talidomida. Mas não dá pra dizer que eles [os testes] não funcionam. Eles não são perfeitos, tem imperfeições. Mas os resultados representaram um avanço enorme para a saúde huamana. (MC)

Chamou nossa atenção o uso da argumentação que justifica a atuação do sujeito ao destacar suas próprias características, ou seja, com foco no indivíduo. O entrevistado faz uso desse tipo de argumentação para ressaltar suas contribuições tanto para a saúde humana - a partir do desenvolvimento de fármacos -, quanto em prol do bem-estar dos animais, já que sua pesquisa com métodos alternativos e sua participação no Concea garantem que menos animais sejam utilizados.

Eu considero que quem faz tudo isso tá fazendo um baita bem pra sociedade. É, eu acho que o meu trabalho fornece benefícios pra ambos os lados. Por um lado, a gente desenvolve fármacos e medicamentos, alguns utilizando animais, mas, enfim, tá colocando no mercado remédios que estão melhorando a vida das pessoas. Por outro, com a pesquisa e validação de métodos substitutivos, a gente já reduz bastante o número de animais utilizados. E tem o Concea, que eu acho

\footnotetext{
11 O entrevistado se refere aos efeitos da Talidomida, substância desenvolvida em 1954 na Alemanha, inicialmente utilizada como sedativo. Em 1957, o medicamento - capaz de ultrapassar a barreira placentária e interferir na formação do feto - gerou milhares de casos de Focomelia, síndrome caracterizada pela aproximação ou encurtamento dos membros junto ao tronco do feto, tornando-os semelhantes aos de uma foca. Fonte: ABPST - Associação Brasileira dos Portadores da Síndrome da Talidomida.
} 
que a gente também contribui nisso, regulamentando e normatizando a questão e fiscalizando as Ceuas, auxiliando para que os 3Rs realmente funcionem.

As frequências dos argumentos apresentados pelo representante do Concea estão apresentadas no quadro abaixo (Quadro 7).

\begin{tabular}{c|c|c}
\hline Membro do Concea & $\begin{array}{c}\text { A respeito do seu } \\
\text { trabalho }\end{array}$ & $\begin{array}{c}\text { A respeito do } \\
\text { trabalho do outro }\end{array}$ \\
\hline Natureza do Argumento & \multicolumn{2}{|c}{ Frequência } \\
\hline Consequência & 5 & 0 \\
\hline Sujeito & 0 & 0 \\
\hline Motivo & 1 & 0 \\
\hline Aspecto Científico & 3 & 0 \\
\hline
\end{tabular}

QUADRO 7 Natureza dos argumentos - Membro do Concea

Foi, foi notória a quantidade de argumentos utilizados pelos ativistas para desconstruir o discurso dos pesquisadores, enquanto o inverso não foi observado. Esse fato pode estar associado às relações de poder inerentes a toda questão controversa e presente também no caso da experimentação animal. A ciência certamente dispõe de mais recursos para aplicar seu discurso no espaço público e maior voz dentro do cenário político brasileiro. Isso talvez explique porque é tão importante para os sujeitos contrários à experimentação animal pôr em xeque os argumentos dos pesquisadores.

Todavia, é necessário que, em ações ou materiais de divulgação científica, outros tipos de argumentos sejam ressaltados, como os que expõem as relativizações e limitações da questão. Conforme apresentado na fala do membro do Concea "o mundo é mais cinza do que preto e branco". Quando o pesquisador é apresentado somente pela visão do ativista, por exemplo, perde-se um pouco a concepção de que as ciências são construídas por seres humanos que nem sempre estão alheios ao sofrimento dos demais organismos.

Isso fica claro no discurso das pesquisadoras entrevistadas para esta pesquisa, que demonstram maneiras diferentes de lidar com a dor do animal. A pesquisadora 1, por exemplo, não realiza trabalhos de bancada, isto é, não atua pessoalmente nos experimentos que envolvem animais, apenas supervisiona o trabalho que é feito por seus 
alunos. Por outro lado, a pesquisadora 2 faz questão de realizar os experimentos e garantir que nenhum animal perca sua vida desnecessariamente.

De novo, eu sou bichóloga, né. Então minha relação com os animais da pesquisa já foi bem passional. Já levei camundongo pra casa, já fiz de tudo, e aí eu sofria muito mais, né. Com o tempo você vai... Agora eu tenho meus orientandos, fico mais afastada dos bichos. Acho que é melhor assim pra mim. E também vem as correrias do dia a dia, coisas mais burocráticas. (P1)

Particularmente eu faço bem os experimentos, quem faz isso aqui no laboratório sou eu, nenhum aluno meu faz, e eu detesto fazer, detesto. O dia que eu sacrifico um animal eu fico chateada. Eu sei que tem gente que não liga mais, mas eu... Não é uma coisa assim tranquila, é duro. (P2)

Essa dimensão sensível da controvérsia, focada nas experiências de seus participantes, pode ser ricamente explorada em ações de divulgação científica, principalmente para a desconstrução dos estereótipos sociais.

Para compreender as contradições nas atividades dos participantes da questão da experimentação animal, analisamos os discursos dos sujeitos à luz da Teoria da Atividade, buscando entender como as tensões dentro e entre as atividades se relacionam com os tipos de argumentos apresentados pelo sujeito.

\subsection{A experimentação animal nas diferentes atividades sistêmicas}

As contradições inerentes à questão da experimentação animal podem ser compreendidas a partir da análise do contexto maior do qual emergem. Por contexto queremos dizer o conjunto de sujeitos, ferramentas, regras, objetivos, resultados e comunidades envolvidos, segundo o modelo conceitual da Teoria da Atividade. Em outras palavras, a compreensão do fenômeno analisado na seção anterior pode ser enriquecida por uma análise da rede de sistemas de atividade dentro da qual as contradições e seus conflitos internos ocorrem. 
Com esta análise esperamos revelar um contexto mais complexo, no qual coexistem diferentes comunidades, seus respectivos sujeitos e objetivos variados, cada um direcionado a um resultado distinto. Para facilitar a leitura, apresentamos a análise da rede de forma segmentada, um sistema de atividade por vez, para posteriormente reintegrar os sistemas a uma visão expandida de toda a rede, com suas inter-relações.

As informações analisadas nesta seção são oriundas das entrevistas semiestruturadas com os participantes envolvidos na controvérsia da experimentação animal.

\subsubsection{A atividade de pesquisa com animais}

A pesquisa com animais é uma prática milenar fruto da curiosidade do homem em compreender a anatomia e fisiologia de outros indivíduos. Animais foram utilizados indiscriminadamente por gerações até que existisse uma preocupação e uma reflexão sobre o direito de utilização de suas vidas para benefício antrópico.

Esse movimento de reflexão, como vimos anteriormente, originou-se das correntes ambientalistas da década de 1970 que questionavam os danos ambientais causados pelas atividades produtivas e de consumo nos países desenvolvidos, e que envolveram em sua causa a questão da experimentação animal.

É desse movimento que a controvérsia sai do círculo de interesse de cientistas e conquista maior visibilidade, alcançando a sociedade civil por meio da atuação de ativistas nos meios de comunicação em massa. No Brasil, a crescente preocupação com o direito animal justificou a criação de uma legislação específica, políticas governamentais e, em última instância, de políticas empresariais. A atividade de pesquisa com animais incorporou dessa forma novas regras que regulam hoje as ações dos sujeitos em questão. 


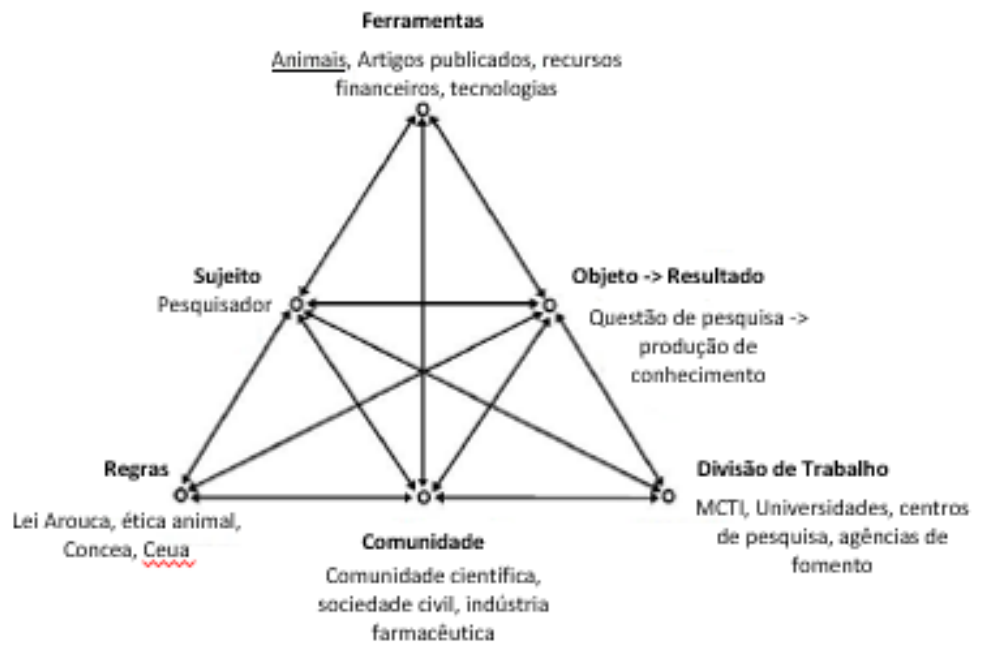

FIGURA 9 Sistema de Atividade da pesquisa com animais

$\mathrm{Na}$ atividade de pesquisa apresentada, os animais são instrumentos pelos quais os sujeitos - pesquisadores - transformam sua realidade visando a produção de novos conhecimentos. A representação gráfica acima (Figura 10) expõe como cada elemento, em um momento específico, está organizado dentro do sistema de atividade.

A partir do discurso dos pesquisadores foi possível mapear algumas contradições nesses elementos e revelar seus conflitos e tensões internos, aqueles que ficaram mais evidentes em nossa interpretação.

Uma contradição bastante relevante se localiza no sujeito da atividade, isto é, na figura do pesquisador. Existe nele um conflito entre os seus sentimentos em relação aos animais, seus princípios e aspectos morais e as ações que conduzem sua atividade. Contudo, essa tensão é superada quando colocada diante dos benefícios à saúde humana e ao avanço da ciência proporcionados pelo uso de animais. O indivíduo reprime, então, suas afeições e emoções por acreditar na relevância do seu trabalho. Isso pode explicar o fato de os pesquisadores apresentarem argumentos quase sempre consequencialistas para justificar suas ações, em detrimento àqueles que focam em suas características próprias.

Ent. O que você sente quando pensa em animais sendo utilizados na pesquisa?

P1: Eu, eu sou bem bichófila, assim. Eu gosto de bicho de maneira geral. Eu gosto e nesse ponto teria um lado que você fala assim: 'ah, dá dó, o bichinho bonitinho', 
então minha tendência é sempre não matar. Por outro lado, eu sou plenamente consciente de que $99.9 \%$ do que a gente faz na medicina teve que em algum momento passar pelo camundongo, ou tiveram descobertas que vieram do camundongo. Então nesse ponto, eu acho que, enfim, tem um benefício que não pode ser ignorado.

P2: [...] É, eu acho que assim, acho que não conseguia fazer cirurgias e coisas desse tipo. Tem uns laboratórios que fazem. Eu não vou te falar que não é necessário. Eu sou a primeira a tomar anti-inflamatório quando tem alguma coisa doendo, entendeu? Então, eu não posso falar nada. Mas, sim, eu acho que isso já seria demais também, né. Não ia conseguir lidar com animal sentindo dor, esse tipo de coisa.

Por outro lado, essa tensão limita a ação do pesquisador, funcionando como um elemento de controle e regulação das ações que compõem sua atividade, como observado na fala do pesquisador 2 , no trecho acima.

Outra contradição importante se encontra na divisão de trabalho da atividade de pesquisa com animais, na forma como as ciências se organizam estruturalmente, em suas instituições e hierarquia. Uma tensão interna é manifestada no discurso do pesquisador quando este deseja exercer um papel de comunicação com a sociedade mais efetivo em relação à experimentação animal, mas é impedido devido a cobrança cada vez maior pelo aumento do seu volume de produção, seja ela acadêmica ou relacionada à docência.

Entrevistador: Como a Ciência, enquanto seus membros, envolve a sociedade nessa discussão a respeito da experimentação animal?

P1: Eu acho que a verdade é que os cientistas afastam a sociedade dessa discussão. Eles deveriam de alguma maneira... O problema é que a gente está sempre perdido em um monte de coisas que ocupam a gente, né. Aqui no Brasil você tem muita pouca infra então tudo é confuso. Mas eu acho que a gente teria que falar mais disso até do lado, sei lá, tentar fazer, sei lá, pra embasar o outro lado da história também.

P2: Deveria ser feito um curso de cultura e extensão, sim, de qual a importância, os prós e os contras disso. Acho que é papel da universidade até discutir, acho muito bom esse projeto que você tá fazendo, porque é papel da universidade fazer isso. Foi o ponto que eu falei pra nossa comissão de cultura e extensão. Falei, acho que a gente deveria fazer, sim. Um vídeo, um curso, alguma coisa de 
cultura e extensão onde você coloque qual a importância disso, quais foram os casos de sucesso, quais foram os casos de fracasso. Mas que horas você monta curso? Que horas você vai fazer isso? Né, então por exemplo, "ah, eu vou tirar umas férias, eu vou tentar planejar de fazer um curso de..." porque agora a CAPES quer que a gente tenha papel no ensino médio. Falei: "gente, sabe, pera aí. Não tô conseguindo nem dar conta disso, até o ensino médio, sabe? "Como assim? O ativista contra tem tempo de fazer isso e os professores que participam do outro lado não tem meia hora pra olhar pro lado. Então, o discurso tá ficando pesado pra um lado, o que pode ter uma influência importante no desfecho disso. Então, talvez a gente pague esse tempo que a gente não tem. Não sei.

O medo da radicalização por parte dos ativistas também é um fator que afasta a ciência da sociedade no diálogo sobre os testes em animais. Como veremos adiante, esse conflito entre dois sujeitos de atividades distintas influencia diretamente nas ações do pesquisador. Essa tensão não superada gera um ciclo de radicalismo/medo/ausência de discussão, no qual os ativistas pautam seus argumentos na desconstrução do trabalho do pesquisador sob uma postura radical, provocando medo nos cientistas e, por consequência, afastando-os das discussões com os ativistas e com a sociedade. Por fim, o debate se torna inviável, bem como a superação da tensão.

Mas, uma das coisas seria isso, seria isso dar a opinião da gente tentando esclarecer até pra escolas, explicar qual é a importância da experimentação animal para o desenvolvimento da Ciência. Mas, dá medo, dá medo você falar "vou entrar nisso aqui" e dá medo de você virar alvo de ativistas. Então você fica naquela dúvida de faço ou não faço. Então eu conheço pessoas que são da bio, que estão trabalhando com o CONCEA e que de alguma maneira se expõem a isso e isso gera um conflito grande e que é difícil. Quem botar a cara pra fazer isso aí vai se expor e, ou você vira um defensor disso, ou você poder virar alvo e se você não quer, vai pular fora. (P1)

Mas mesmo do lado dos ativistas eu acho que eles passam muito do limite com muitas coisas. O "galho" é a partir do momento que você começa a ficar violento você perde a razão, entendeu? Então, é muito complicado. A princípio é uma coisa que eu simpatizaria, porque eu sou a primeira a ficar louca se eu vejo alguém maltratando um animal. Qualquer coisa eu fico desesperada, eu vou em cima, falo, não sei o que. Mas, a partir do momento que você pega uma coisa, por exemplo, uma organização de comissões de ética que tá tentando discutir 
como que você vai fazer isso melhor e tal, e daí você vai lá e agride as pessoas, é complicado. (P2)

A falta de um diálogo aberto com a sociedade engendra ainda conflitos entre sujeito e comunidade, dentro do sistema de atividade de pesquisa. Por um lado, o público, pelas razões citadas no parágrafo anterior, não está familiarizado com outros tipos de argumentos e discurso dos pesquisadores, senão aqueles veiculados na mídia, que fornecem uma visão dual do fenômeno. Por outro, a ciência não manifesta seu interesse de ouvir a sociedade por meio de pesquisas de percepção e opinião pública principalmente pelo receio dos resultados afetarem sua atividade com animais.

Segundo Laurent (2015), na maior parte das vezes, o diálogo em uma controvérsia é problemático não por causa da representação da questão, mas devido a representação do público que ainda não é clara. Por isso é tão relevante o acompanhamento da opinião pública que proporcione um feedback contínuo sobre a percepção da sociedade a respeito da experimentação animal. Mais que isso, é necessário fornecer ao público a oportunidade de participar do diálogo, mostrando-lhe que sua percepção pode contribuir para o desenvolvimento de ações políticas concretas.

Portanto, quando as tensões estruturais de uma atividade não são superadas, suprime-se o seu potencial para mudança da atividade e para aprendizagem dos sujeitos e o avanço qualitativo na questão. Isso não significa, porém, que a atividade está estagnada. Por meio do discurso das pesquisadoras, ficou claro que há um movimento em direção à superação das contradições, a partir de questionamentos sobre ações de outros pesquisadores e da própria prática em relação à sociedade.

\subsubsection{Atividade de proteção animal}

A atividade de proteção animal representada na Figura 11 se estrutura ao mesmo tempo que a atividade de pesquisa com animais incorpora novas regras. Isto é, seu início que deriva da crescente preocupação ambiental discutida na seção anterior - transforma a atividade de pesquisa com animais ao produzir um conjunto novo de elementos que constituem as regras dessa atividade. 


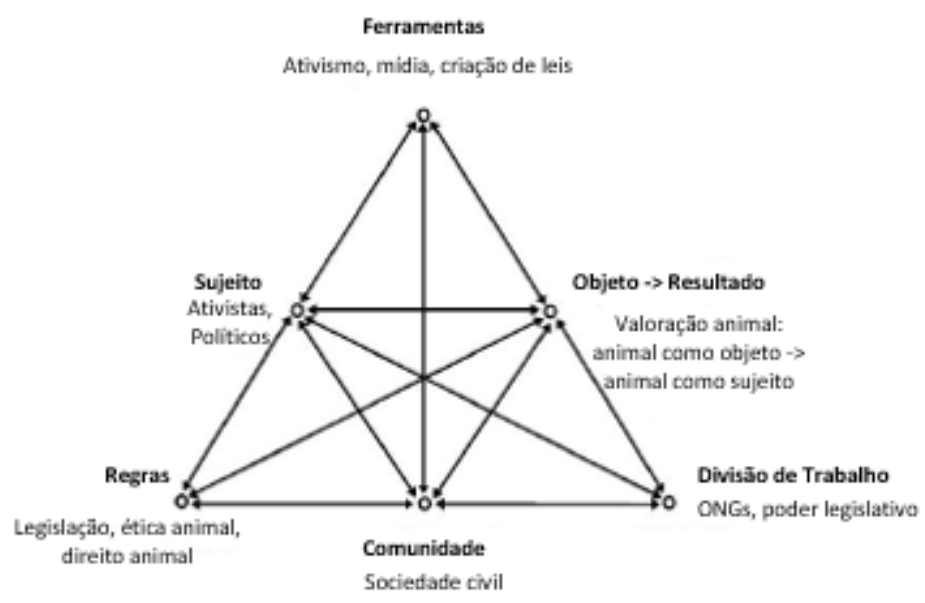

FIGURA 10 Sistema de atividade de proteção animal

O conjunto de ações que compõem a atividade de proteção animal funcionam, dessa forma, como reguladoras da atividade de pesquisa com animais, no sentido de limitar e controlar as ações dos sujeitos que utilizam os animais como instrumentos de investigação. O modelo gráfico acima, no entanto, está longe de representar a complexidade existente dentro do sistema de atividade em discussão.

Tanto os membros de sociedades de proteção animal, quanto o político envolvido com a causa, foram identificados como sujeitos desta atividade, por manifestarem a mesma necessidade, o mesmo motivo. As ações direcionadas de ambos se fundamentam na razão da valoração do animal, em caráter final, mesmo diferindo em seus modos - com sentido abolicionista, entre os ativistas, e voltado para a garantia do bem-estar animal, no caso do político. Na prática, essa relação indica que a atribuição do animal como sujeito, que deve gozar de seus direitos fundamentais, é elemento causal dentro das ações, sendo este, portanto, o objeto da atividade.

Este objeto em transformação é o que fundamenta a atividade de proteção animal, porém, cabe lembrar, que os elementos de uma atividade são dinâmicos e o que ora é instrumento pode se transformar em objeto. Da mesma forma as ações podem se tornar atividades. No caso da atividade de proteção animal, a criação de leis é para o político uma ação, mas pode ser, ou foi em algum momento uma atividade. 
As ações do político, por uma série de questões práticas, estão muito mais concentradas em garantir a redução do número de animais utilizados em testes científicos e o menor sofrimento possível daqueles que são instrumentos de pesquisa. Contudo, fica bastante claro em seu discurso que a necessidade que embasa e estrutura essas ações é libertação do animal, o abolicionismo.

A natureza jurídica do animal, ele é considerado uma coisa, um objeto, e não um sujeito que tem direitos. Mas ele sente dor, sofre, tristeza, alegria, tudo. Então ele merece ser tratado como um sujeito que tem direitos, não obrigações, mas direitos ele deveria ter. Então é por essas mudanças que a gente vem brigando. (PO).

Eu acho que se a gente conseguir chegar na abolição total é melhor, mas tem casos que a gente não consegue. Ou não consegue por causa da questão cultural ou da questão científica. Então onde não der, o quanto a gente conseguir aplicar mais o bem-estar e diminuir o número de vidas utilizadas é bom, mas onde a gente puder ter a abolição total, a gente deve aplicar a abolição total (PO)

Os animais são utilizados desnecessariamente. Se a gente puder aplicar testes alternativos pelo menos aqueles que diminuem o número de animais, já vai ser um ganho de vidas que a gente vai estar economizando. (PO)

O importante é que com uma lei como essa a gente não salva $100 \%$ dos animais utilizados em desenvolvimento de cosméticos, mas salva 90\% deles. (PO)

Os ativistas por outro lado, mantém a linha de suas ações voltada para a garantia do direito à vida, mas compreendem, de certa forma, que o processo para alcançar esse objetivo maior inclui algumas etapas relacionadas ao bem-estar animal, dados o cenário político e o contexto brasileiros.

Ana, uma vez que os animais são objetos de uso na nossa cultura e que fazer proteção animal quantas vezes é motivo de chacota, né, então a gente precisa dar os passos um de cada vez. (A1)

Então não testa vacina nos animais e não vai ter vacina pra inocular no ser humano e protege-lo de uma doença? Então tem que ter vacina, né. Mas a forma é testar nos animais? Por que a gente tem esse atraso tão grande nessas áreas, biológicas, que testam em animais? Se nós tivéssemos um grupo de cientistas, 
esse mesmo grupo de cientistas pesquisando materiais e formas alternativas de testes, isso não seria possível de acabar em poucos anos? (A1)

A complexidade dessa atividade também se manifesta nos aspectos emocionais e afetivos que motivam as ações dos ativistas. Tais aspectos já eram reconhecidos por Leontiev como sinais da construção subjetiva dos motivos relacionados aos objetos, aos quais não se tem acesso de forma consciente. Assim, afirma Engeström, "para ter acesso aos motivos, deve-se caminhar, de forma indireta, descobrindo experiências emocionalmente marcantes" (ENGESTRÖM, 2009, p. 308).

Esses aspectos emocionais também estão visíveis na argumentação dos ativistas para justificar seu trabalho, centrada predominantemente no motivo, na construção da prerrogativa máxima de que os animais devem ter um fim em si mesmo.

Entrevistador: Quando pensa em animais sendo utilizados em pesquisas e testes farmacêuticos, o que você sente?

A1: Eu sinto o meu peito contraindo, sinto um aperto no meu coração. Eu sinto uma emoção, em primeiro lugar, depois eu sinto indignação, eu sinto raiva, incredulidade que a gente faça essas coisas com os animais. [...]. Então eu acho que eu fico muito indignada e disso vem as minhas reflexões e isso é um ponto pra estudar, pra eu tentar fazer alguma coisa por eles.

\section{Entrevistador: Como foi sua experiência na Ceua?}

A1: [...] Aí, eu ouvi, eu ouvi tudo o que foi dito, né, como que era a composição dos projetos, como que eles propunham também o jeito de fazer a eutanásia. $E$ aí eu tive contato assim, com um vocabulário como descarte, descarte do material, que significa descarte dos corpos usados. Carcaça, descarte das carcaças, era essa a expressão. Aí o que eu pensava do animal, vivo, interagindo, dono dos seus cinco sentidos e tendo uma autoconsciência virou uma carcaça que precisava ir para o descarte, que precisava acontecer de uma forma, por incineração. [...] Então eu só fui numa reunião, vi como era o negócio e me retirei. Não dá pra mim. Muito pesada essa situação. Eu fui porque eu queria contribuir, mas não tem jeito de contribuir, a não ser eu estudar, estudar, estudar pra saber, pra achar uma forma de melhorar a vida deles. 
Em relação às contradições internas do sistema de atividade em discussão, nossa análise identificou que elas se localizam principalmente nos sujeitos da atividade. 0 conflito entre os aspectos morais do sujeito e sua ação efetiva, assim como na atividade de pesquisa com animal, ficou bastante evidente.

É, eu sou contra, mas eu não sou radicalmente contra. E eu te digo o porquê. Eu já estive duas vezes em Salvador, por exemplo, (e eu vou dar mais um exemplo humano) e lá eu entrei em alguns prédios que tinham sido construídos antes de 1888, eles foram construídos por escravos. Eu sou totalmente contra a escravidão, mas eu não vou dizer: "ah eu não vou entrar em nada que foi feito por escravos". (A2)

Mas eu estou lá, faço parte desse grupo de trabalho e sou uma vegana abolicionista, mas eu nem ouso falar nada, ne, porque as pessoas que estão lá defendendo os cães e gatos e propondo política, entre eles existem pecuaristas. E as pessoas que estão lá, que fazem parte desse grupo não são vegetarianas, não são veganas, não estão preocupadas com isso daí. Então tá, eu vou ficar quieta, vou ficar na minha, né, e não vou falar as outras coisas, não posso falar dos outros bichos, ali naquele momento não posso falar dos camundongos, dos invertebrados, porque senão eu caio num descrédito, você entende? (A1)

Como a atividade em questão é composta por sujeitos diferentes, motivadas pela mesma necessidade, mas executando suas ações de forma distinta, também foram evidentes os conflitos dessa natureza. O político para alcançar sua meta - oferecer o maior bem-estar animal possível - desenvolve ações (elaboração de leis) que estão em desacordo com os objetivos dos ativistas e de seus próprios motivos - garantir o abolicionismo animal.

Entrevistador: Você acha que os comitês de ética representam um avanço pra essa questão?

A2: Não, não. Não representa avanço algum. Na verdade, eles são instituições criadas pela lei Arouca, uma lei que eu combati, eu combati a criação dessa lei, combati a criação do Concea, que nada mais é que o instrumento de legitimação. Não que a experiência já não acontecesse, mas uma vez que você regulamenta você tá oficializando.

Contudo, essas distintas formas de atuação geram também tensões na divisão de trabalho da atividade de proteção animal, como destacado no trecho abaixo: 
Então existe, existe muito isso de muitas ONGs que não estão trabalhando de forma coordenada, com o mesmo objetivo, mas se desdizendo, batendo a cabeça. Isso acontece bastante. Uma acaba contradizendo a outra. Porque existem ONG' que são de proteção animal e não são de Direitos Animais. (A1)

Outra tensão, ainda relacionada às ações do sujeito, refere-se ao ativismo, entendido aqui como ferramenta pela qual o sujeito - neste caso o ativista - transforma seu objeto. No discurso analisado, o ativismo aparece ora para tentar convencer a sociedade a partir dos argumentos contrários à experimentação animal, ora como instrumento de fomento do debate público, conferindo-Ihe autonomia em suas escolhas e tomada de decisão.

As principais contradições entre os sistemas de atividades se localizam principalmente entre o sujeito das atividades de proteção animal e o de pesquisa com animais. A tensão mais evidente está na visão estereotipada do pesquisador por parte dos sujeitos contra a experimentação animal, que é manifestada por meio de argumentos com foco na descaracterização do trabalho do cientista, como discutido no capítulo anterior. Nos trechos abaixo é possível observar que o ativista destaca os defeitos do cientista da área hard, como ser cruel, insensível à dor de outro animal, colocando do lado extremo os pesquisadores da área de ciências humanas.

Entrevistador: Não seria papel da ciência discutir o que ela faz internamente com o restante da sociedade?

A1: As ciências biológicas, as ciências da área hard, como elas fazem experimentação animal, elas obviamente não vão fazer isso. Porque, hoje em dia, elas precisam do animal pra ter o resultado lá, pra dar o andamento da pesquisa. Se seria papel delas também? Poxa vida num mundo utópico, isso aconteceria, né. Mas pelo menos agora está sendo papel das ciências humanas, né.

Então eu acho que sim, Ana, acho que se as pessoas soubessem o que acontece, os cientistas que fazem esses experimentos seriam vistos com menos admiração. A ciência perde credibilidade, mostra a crueldade que existe dentro dela. (A1)

E existe, pelo o que eu estou vendo da composição do meu grupo, existe essa sensibilidade nas pessoas de humanas. Elas são, na grande maioria, contrárias à experimentação animal. (A1) 
Ainda focando na questão dos estereótipos, foram localizadas, principalmente no discurso dos ativistas, diversos estereótipos sociais, configurando um conflito entre o sujeito da atividade e representantes de sua comunidade, a sociedade em geral.

[...] tem o cara que é ativista, uma dona de casa, por exemplo, que é ativista e que vai gritar, vai ofender uma pessoa ao se colocar, porque ela age por paixão e ela não tem a estratégia, não tem a calma também, né. $E$ as vezes ela tem um problema pessoal e ela acaba também descontando na causa e isso é muito comum, né. (A2)

É, existe uma correlação. Não é uma única pesquisa que mostra, né. Por exemplo, o hábito alimentar vegetariano é mais associado a mulheres. Porque o homem tem que ser machão, ele tem que comer carne mesmo, senão ele vai ser considerado menos homem. Então se um homem se mostrar sensível ao sofrimento animal, ele pode ser considerado menos homem. (A2)

É que o jovem nasceu em outra época, em que ele pode ser, pode falar exatamente o que está pensando. Ele não precisa pensar: 'se eu falar tal coisa vão achar que eu sou boiola, desculpa a palavra, vão achar que eu sou homossexual'. Então o jovem já não tem essa preocupação, talvez porque ele não relacione a sensibilidade com o homossexualismo, e talvez porque ele não esteja com medo do que alguém vai pensar. (A2)

Então, ela era uma pessoa dona de casa, que não estava envolvida nesse mundo acadêmico nem nada, completamente ignorante disso que acontecia. Ou seja, isso não é divulgado [sobre marcas de produtos de limpeza que não testam em animais]. (A2)

Um conflito que também se evidencia na última fala dos trechos apresentados se refere aos modelos de divulgação científica, predominantemente pautados na lógica do mercado. Segundo a ativista a falta de interesse em divulgar as marcas de produtos de limpeza que não testam em animais está relacionada ao fato de que, dessa forma, a ciência é poupada do diálogo com o público, que poderia ser acarretada pela divulgação dos produtos. 
Acho que falta divulgação, mas falta divulgação porque falta interesse em divulgar. E falta interesse em divulgar porque esse é um assunto para o qual ninguém está nem aí, não é? As grandes marcas de cosméticos e produtos de limpeza vão estar de que lado? Do lado onde ganham mais. (A1)

Nesse jogo de interesses, mais uma vez se manifestam as relações de poder que definem a questão da experimentação animal e a assimetria do discurso científico sobre o espaço público em comparação ao discurso dos defensores dos direitos dos animais.

Tensões entre a atividade de proteção animal e atividade de regulação da experimentação animal, desenvolvida pelo membro do Concea também se destacam em nossa análise. A principal questão está na forma como o conselho é composto e os elementos de sua comunidade. Para os sujeitos contrários à experimentação animal, as Comissões de ética do Concea são tendenciosas e atuam mais como instrumento político do que na regulação e controle da experimentação animal no país.

Eu não acredito nas comissões de ética do Concea, pra falar a verdade. Eu acho que a composição ela não é igualitária, entendeu. Ela é uma composição tendenciosa, as indicações do conselho de ética, do Concea, não são totalmente independentes e imparciais. (PO)

\subsubsection{A atividade de regulação da experimentação animal}

A atividade desenvolvida pelo membro do Concea foi interpretada como uma atividade de regulação, cujo o objeto é a própria experimentação animal, que deve seguir conforme as determinações das resoluções e normas produzidas pelos sujeitos da atividade, conforme apresenta a Figura 12. 


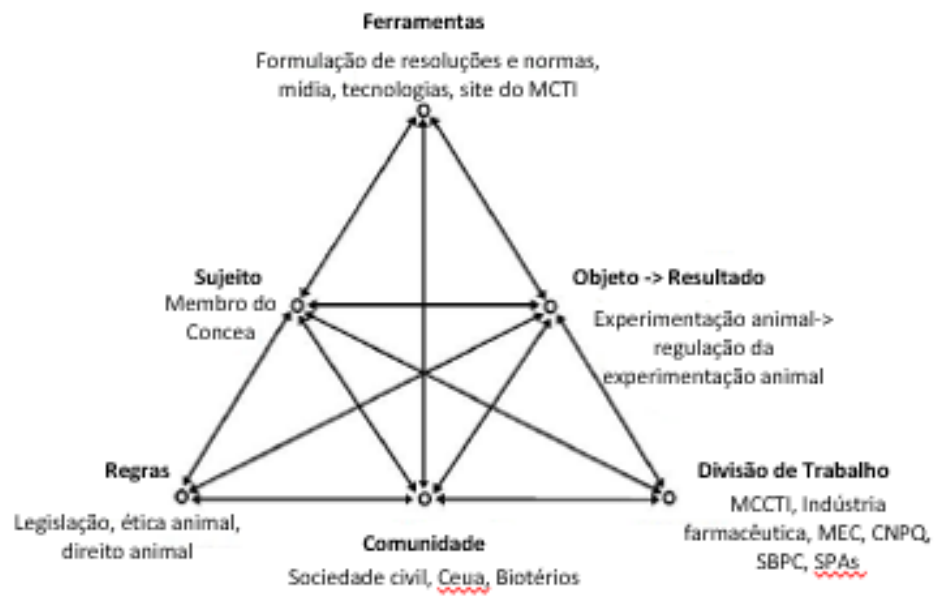

FIGURA 11 Sistema de atividade de regulação da experimentação animal

Nesse sistema de atividade foram percebidas três contradições principais localizadas no sujeito, na comunidade e na divisão de trabalho. A tensão sobre as ações do sujeito está relacionada à composição do Concea, seus membros e posições ocupadas. Existe um conflito na legitimidade do envolvimento dos membros com as sociedades de proteção animal e na sua participação efetiva no Conselho.

[...] o Concea é composto por setores, diversos setores da sociedade, né, com interesse na questão da experimentação animal. Tem representantes de ministérios, ciência, educação, meio ambiente, CNPQ, representantes da indústria farmacêutica, e um pessoal da proteção animal, enfim, todos os setores que tem algum interesse na experimentação tá lá, só não tá quem quer proibir a experimentação. (MC)

É, mas acontece que tem muito jogo político, né, ninguém vai colocar um cara que vai ficar questionando tudo e brigando por qualquer coisa, senão não anda, né, não trabalha. Essas pessoas [representantes de SPA] geralmente, e atualmente é assim, é um pesquisador preocupado com o bem-estar animal que se filia a SPA pra poder participar do conselho, isso é comum, nas Ceuas também é assim, acho válido até. Mas talvez eu, que trabalho com métodos alternativos, atuo mais nessa questão do quem é membro de SPA, ainda bem que eu tô lá [risos]. (MC) 
A tensão relacionada à comunidade também se refere à sua composição, mas estende-se por sua atuação nas instituições de pesquisa no sentido de regulamentar e fiscalizar o uso de animais utilizados nas investigações. De acordo com o entrevistado, nem todas as comissões de ética possuem a seriedade necessária para: 1) selecionar seus membros; 2) avaliar os projetos de pesquisa; 3) fornecer o retorno necessário ao Concea; como pode ser observado no trecho abaixo:

As Ceuas são ótimas, veja bem, a implantação de comissões de ética em cada instituto de pesquisa, cada universidade, departamento, isso é fantástico, é um avanço imensurável pra questão do uso de animais no Brasil. Agora, como tudo, tem aquilo que funciona e aquilo que não funciona muito bem. Então, né, você tem comissões formadas por amigos? Tem. Comissão que aprova só os projetos de seu interesse? Tem. Comissões que fazem relatório de qualquer jeito, que não exige relatório dos seus pesquisadores? Tem, sempre tem. Isso é Brasil né, Mas olha, tava muito pior sem as comissões de ética, muito, muito. Isso com o tempo, dá pra arrumar. (MC)

A última tensão estrutural localizada no sistema de atividade de regulamentação da experimentação animal está na divisão de trabalho e abarca os interesses políticos dos órgãos que compõem o Conselho. Embora, os representantes de cada órgão constituam o Conselho, em nossa interpretação o conflito em questão extrapola o indivíduo em si, localizando-se em uma esfera superior.

[...] coloca um monte de gente com interesses diferentes no mesmo lugar e vê se vai ser calma a situação. É como eu falei, tem jogo político, claro. A indústria farmacêutica puxando sardinha pro seu lado, querendo só os métodos alternativos que interessam, o MCTI puxando pro outro, o CNPQ pro outro, quem cede quer algo em troca, tem isso, tem sim, é política. Mas de qualquer forma, acho que o trabalho tá sendo feito e tá funcionando em muitos aspectos [...]. (MC) 


\subsubsection{A rede de sistemas de atividade que compõem a questão da Experimentação Animal}

A interpretação das contradições e conflitos internos, aliada às análises apresentadas nas subseções anteriores, sugere a possibilidade de avaliação do fenômeno aqui estudado como uma rede de sistemas de atividade. A configuração geral simplificada dessa rede é apresentada na Figura 13. De acordo com a representação gráfica apresentada, a questão da experimentação animal é composta, pelo menos, por três sistemas de atividade. No entanto, entendemos que a atividade de pesquisa com animais é a atividade central (ou focal) da questão, já que sem ela não existiria a controvérsia.

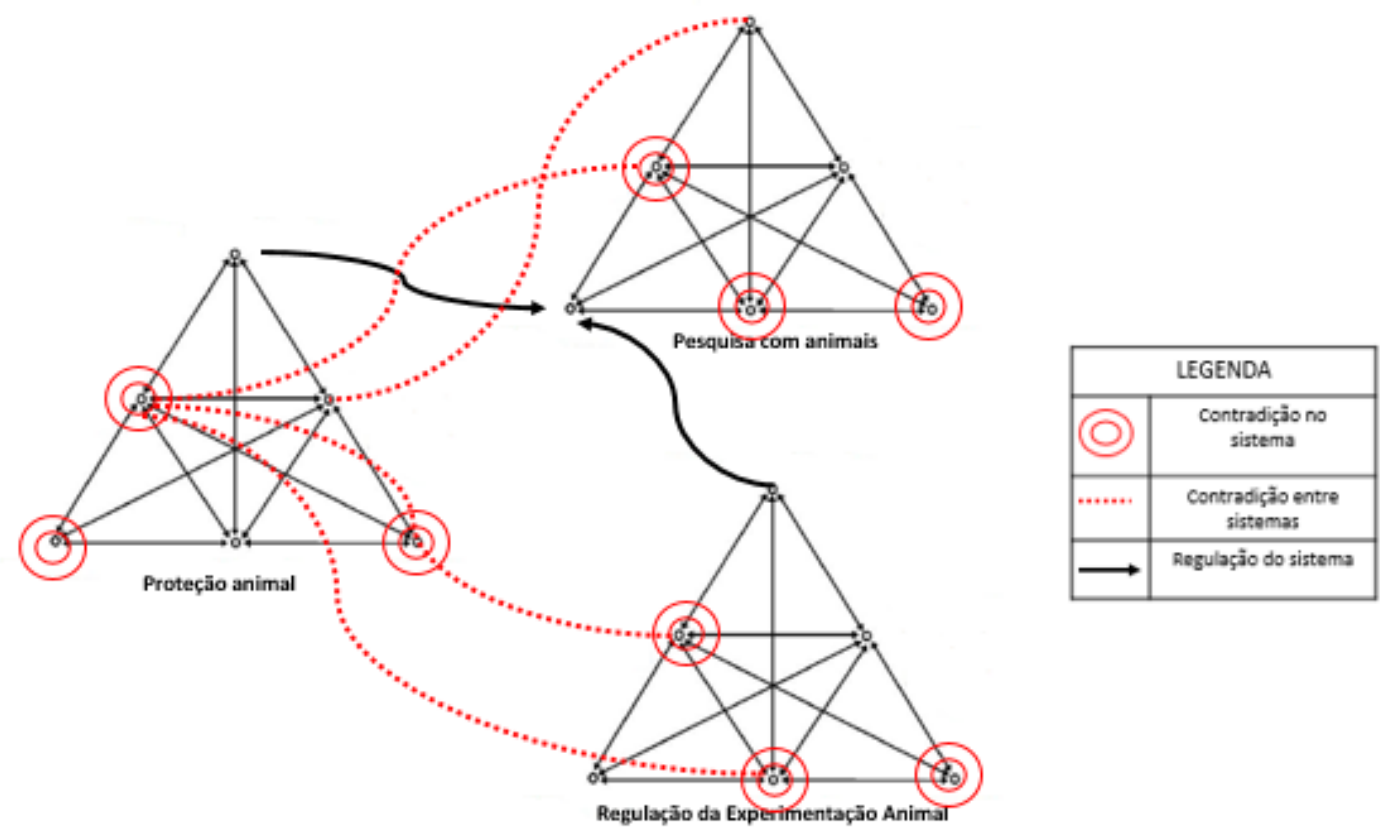

FIGURA 12 Rede de Sistemas de atividade da questão da experimentação animal

As duas outras atividades funcionam como reguladoras do sistema focal, atuando principalmente sobre as regras dessa atividade. Na medida em que os sujeitos da atividade de proteção animal desenvolvem novos instrumentos - formas de ativismo, novas leis determinam a maneira como estarão direcionadas as ações dos pesquisadores. Da mesma forma, a produção de novas resoluções, diretrizes e normas pelo Concea atua diretamente sobre as regras da atividade de pesquisa com animais. 
O esquema apresentado também aponta as tensões mais evidentes dentro e entre os sistemas de atividade. Em resumo, as principais contradições evidenciadas em nossa interpretação se localizam entre:

1) os sujeitos das três atividades;

2) o sujeito da atividade de proteção animal e a comunidade da atividade de regulação da experimentação;

3) o objeto da atividade da proteção animal e as ferramentas da atividade de pesquisa com animais.

Esta última é especialmente relevante, pois, à medida que os sujeitos da atividade de proteção animal transformam seu objeto, ou seja, configuram socialmente o valor do animal como sujeito, esse deixa de integrar os instrumentos da atividade de pesquisa, transformando a atividade de regulação da experimentação animal em uma nova estrutura.

Foi esse movimento que originou, historicamente, a rede de sistemas de atividade que podemos observar hoje no contexto brasileiro. A atividade de pesquisa animal foi a primeira a se originar, a partir da necessidade humana de compreender certos fenômenos. Os animais, desde então, compõem os instrumentos desta atividade. No entanto, contradições entre sujeito (pesquisador) e comunidade (outros membros da sociedade) incorporaram novas regras ao sistema (leis de crimes ambientais, pressão dos ambientalistas e defensores dos animais, etc.). Parte dessa comunidade, formada principalmente por ativistas e políticos envolvidos com a causa, ao deslocar seus motivos a outro objeto engendraram um novo sistema, a atividade de proteção animal. A produção de novos instrumentos dessa atividade, ao atuar diretamente sobre as regras da atividade de pesquisa com animais origina, finalmente, a atividade de regulação da experimentação animal, a partir da implementação da Lei Arouca.

Apesar de não termos evidenciado a estruturação de novos sistemas de atividades, por meio da superação das contradições na configuração atual da rede, compreendemos que está em curso um movimento em direção a essas superações. A reflexão e o 
questionamento do sujeito sobre suas ações abrem espaço para diálogo e negociações, por exemplo, com o público. Esse avanço poderia ser ainda otimizado se os atores envolvidos estivessem inseridos em um ambiente favorável para a superação das contradições.

\section{NOVOS CAMINHOS DE PESQUISA E PRÁTICAS}

Com o intuito de apontar subsídios para a elaboração de estratégias de DC sobre a temática da experimentação animal, esta investigação analisou dialeticamente duas dimensões da controvérsia em questão, a partir dos discursos dos participantes: os tipos de argumentos utilizados e sua natureza, a partir de categorias pautadas na Teoria da Moral e as contradições e conflitos inerentes à questão, sob a ótica da Teoria da Atividade.

Foi observado que os argumentos que pautam o trabalho dos membros da controvérsia - que foram analisados - estão centrados nas consequências que ele gera; nos aspectos morais do sujeito que atua, nos motivos para executar a ação e no aspecto (dado) científico.

Para enriquecer essa análise e compreender as relações por trás do uso desses argumentos, investigamos as contradições e tensões entre as atividades dos diferentes sujeitos. A principal categoria de contradição encontrada está na questão da valoração do animal. Enquanto os sujeitos da atividade de proteção animal interpretam o animal como fim, destacando seu valor intrínseco, os sujeitos das demais o entendem como meio.

Isso desencadeia o surgimento de diversas outras contradições, dentro e entre os sistemas de atividades. Essas tensões precisam ser exploradas por ações de divulgação científicas, para a aproximação do público com uma visão menos dual da questão.

Por isso sugerimos as conferências de consenso como estratégia de comunicação científica para um diálogo mais intenso em temas controversos, na qual especialistas e público podem expor seus argumentos e tensões, enfrentando seus modos de racionalidade e construindo coletivamente políticas públicas relacionadas à questão. 


\section{As Conferências de consenso como alternativa para a superação das contradições}

A conferência de consenso é uma ferramenta específica para promover o avanço em questões complexas quando a ausência de um entendimento partilhado bloqueia o desenvolvimento de políticas. Consolidadas na Dinamarca, essas conferências são convocadas quando um determinado tema científico ou tecnológico causa polêmica, dúvidas ou temores na sociedade. Podem ser realizadas também quando determinada instituição deseja explorar a opinião pública sobre algum assunto, idealmente, bem específico, controverso e de amplo interesse público (GOVEN 2003).

O termo conferência de consenso tem sua origem na avaliação de tecnologia ${ }^{12}$ dos Estados Unidos, processo ainda amplamente utilizado para certos tipos de conselho de especialistas em questões médicas. A compreensão da conferência de consenso como um exercício deliberativo baseado nos cidadãos, no entanto, surgiu na cultura política dinamarquesa da década de 1980, conhecida pela experimentação de práticas inclusivas e participativas (LASSEN, 1999).

O modelo dinamarquês de conferência de consenso apoia-se numa abordagem enfática de democracia. Além de disponibilizar canais de influência na tomada de decisão política para as pessoas, essa estratégia de comunicação científica visa inverter a hierarquia entre "leigos" e especialistas (EINSIEDEL; EASTLICK, 2000). O procedimento prevê que "cidadãos comuns" se envolvam em um debate sobre uma questão complexa, principalmente de caráter científico-tecnológico, com o objetivo de alcançar uma posição comum, o que, por sua vez, pode servir como recomendação para os políticos decisores.

O resultado da conferência é a produção de um documento final, geralmente composto por recomendações políticas que avançam no conflito em questão. Constituemse então como um método adequado para discussões de assuntos relacionados à ciência e tecnologia, pois permitem um debate entre especialistas e não-especialistas que contribui

\footnotetext{
${ }^{12}$ A avaliação de tecnologia é um processo que visa a regulação, incorporação e utilização de tecnologias, principalmente na área da saúde, iniciada nos EUA e praticada no mundo inteiro, inclusive no Brasil. "A avaliação de tecnologias em saúde é uma forma sistemática de sintetizar evidência científica e a perspectiva de diferentes atores sobre os aspectos decorrentes da incorporação de tecnologias. Assim as decisões, tendo por base uma avaliação prévia, têm como vantagem a explicitação dos critérios de decisão e a possibilidade de participação da sociedade" (BRASIL, 2009, p.12).
} 
para a elaboração de políticas públicas, por meio de documentos elaborados com base no consenso dos participantes. É importante ressaltar que o 'consenso' é entendido aqui não necessariamente como um acordo mútuo em que todos os envolvidos partilham o mesmo sentido, mas um produto que expressa diferentes vozes, nem sempre com pontos compartilhados por todos.

Acreditamos que as conferências de consenso configurem uma ferramenta valiosa para a superação das contradições localizadas na rede de sistemas de atividade da controvérsia da experimentação animal, ao permitir que sejam colocados em cena os diversos sujeitos envolvidos na questão, seus argumentos, motivos e experiências. É uma oportunidade para que os sujeitos expressem suas emoções e os aspectos afetivos de seu trabalho que compõem a dimensão sensível da controvérsia, ainda pouco contemplada em exposições e ações museais, por exemplo. Além disso, o diálogo direto com o público contribui para a formulação de novos argumentos, pautados em uma reflexão mais profunda e ampla da realidade.

As discussões que sucedem em uma conferência de consenso permitem ao mesmo tempo uma compreensão mais profunda das demais unidades que compõem a questão e o rompimento dos estereótipos formados a partir de uma percepção superficial do fenômeno. Sua análise pode, portanto, revelar como as contradições movimentam os sistemas de atividade a partir da reformulação de seus elementos estruturais e os processos de aprendizagem dos sujeitos que, ao se tornarem conscientes dessas tensões, almejam a criação de uma nova forma de atividade.

Além disso, o caráter deliberativo desse processo, possibilita que a formulação de políticas públicas para a ciência e tecnologia sejam compartilhadas com o restante da sociedade reconhecendo que pessoas comuns são intrinsicamente parte do processo do fazer científico e tecnológico. 


\section{Conferência de Consenso sobre a experimentação animal: uma proposta de ação deliberativa}

Como apresentado na seção anterior, uma conferência de consenso reúne especialistas e cidadãos comuns em um diálogo profundo sobre uma determinada controvérsia. São considerados especialistas aqueles sujeitos envolvidos diretamente na questão, ainda que seus posicionamentos sejam contrários. No caso de uma conferência sobre a experimentação animal podem ser convidados, além dos sujeitos ouvidos nesta investigação - pesquisadores, ativistas, político, membro do Concea - outros grupos com interesse na temática, como representantes de indústrias farmacêuticas e cosméticas, técnicos de laboratórios e biotérios, advogados especialistas em direitos dos animais, filósofos do campo da ética animal, entre outros.

Nas conferências de consenso, as questões centrais da discussão são formuladas pelo painel de cidadãos, grupo composto por voluntários que possuem interesse em discutir a temática com os especialistas. A escolha desse grupo, no entanto, deve respeitar alguns critérios relevantes para manter a integridade do processo e validar seu resultado tais como: idade, sexo, nível de educação, ocupação e habitação, entre outros - a fim de representar um amplo leque de opiniões e atitudes. É muito importante que nenhum dos participantes tenha perícia no tema em discussão ou seja membro de alguma comunidade com interesse na área.

Para a composição desse painel, formado por 10 a 16 pessoas, são divulgados nos grandes meios de comunicação de um país, anúncios informando a sociedade sobre realização da atividade. Acreditamos que no Brasil, a discussão é mais rica quando realizadas conferências nas diferentes regiões, fornecendo um panorama das diversas realidades que compõem a questão no país. Todavia, compreendemos a urgência em discutir o tema em profundidade no estado de São Paulo, palco de acontecimentos polêmicos sobre o uso de animais em pesquisas nos últimos anos.

A conferência aqui proposta, por ter uma abrangência menor, funcionará como um piloto para avaliação e reformulações da ferramenta para práticas futuras em maiores proporções. 
As atividades que precedem a conferência incluem a apresentação dos membros do painel de cidadãos; o fornecimento de explicações a respeito do método e de informações sobre a experimentação animal, por meio de palestras, por exemplo; a formulação da primeira versão das questões-chave e a indicação do tipo de especialistas que deverão respondê-las. Está sob responsabilidade dos cidadãos decidir quais questões serão discutidas e os sujeitos que o farão.

Por isso é importante que, nesse momento, os especialistas revelem não só seus pontos de vista e argumentos, mas as motivações que os sustentam, a partir de suas experiências, emoções e afetos, componentes fundamentais da controvérsia.

As conferências de consenso duram em média três dias e se constituem por breves apresentações dos especialistas na tentativa de responder às perguntas formuladas pelo grupo de cidadãos. A cada apresentação, o grupo tem a oportunidade de reformular suas questões, retirando ou acrescentando pontos que consideram relevantes para a discussão. Essa constante reformulação possibilita que o público se veja diante de tensões e, no caminho para superá-las se depare com novos questionamentos. Dessa forma, a sociedade, representada na conferência pelo painel de cidadãos, poderá refletir sobre as relativizações da experimentação animal, discutindo as situações nas quais os benefícios humanos podem se sobrepor ao sofrimento animal, e os aspectos que devem ser superados na prática da experimentação.

É resultado desse debate a elaboração do documento final que pode incluir recomendações políticas para os aspectos ainda no entrave do cenário paulista/brasileiro, como o uso de animais para a produção de cosméticos e produtos de limpeza e a inclusão de invertebrados nas regulamentações da legislação vigente. Esse documento, que representa o consenso, no sentido de abarcar diferentes vozes, deve ser exposto ao público, à mídia e, principalmente aos políticos, especialmente aqueles mais relevantes na controvérsia da experimentação animal.

Essas recomendações contribuem para o desenvolvimento de políticas públicas, para o estado de São Paulo, na medida que desmonopoliza as decisões normalmente deliberadas a partir dos argumentos científicos, já que a ciência é quem possui maiores recursos para aplica-los no espaço público. 
Realizar uma conferência de consenso sobre a experimentação animal se mostra, então, como importante estratégia tanto por sua dimensão comunicativa, para divulgação científica, quanto em seu aspecto deliberativo.

Outra estratégia que contribui para a compreensão da controvérsia da experimentação animal é a remodelação dos tradicionais surveys, a partir do seu potencial como ferramenta de divulgação científica. Apresentamos na seção seguinte como essas pesquisas podem fornecer dados de percepção e opinião do público e ao mesmo tempo possibilitar e incentivar a reflexão sobre o tema.

\section{Os surveys como instrumentos de divulgação científica}

A pesquisa survey pode ser descrita como um processo de coleta de dados ou informações referentes a características, atitudes e opiniões de determinado grupo de pessoas, que representa um público-alvo. É utilizada, principalmente, para a compreensão de como e porque algo está acontecendo (FREITAS et. al, 2000).

Nesta investigação, buscou-se compreender a percepção do público de um museu de ciências a respeito da controvérsia da experimentação animal, visando a implementação de uma possível exposição sobre a temática no local. E, embora essa pesquisa pública não tenha se caracterizado como survey, pelos motivos discutidos no capítulo 4, é originaria dela a percepção do potencial dessa ferramenta para o fenômeno estudado.

Durante a aplicação do questionário ficou claro que a temática da experimentação animal não integrava o repertório conversacional dos visitantes. Isto é, para a maioria dos respondentes, a primeira oportunidade de refletir sobre a temática se encontrava na pesquisa. Uma alternativa para essa questão seria a transformação da própria pesquisa em um instrumento de divulgação científica, fornecendo, por meio dela, os subsídios necessários para uma reflexão sobre o tema.

Se as pessoas pudessem se deparar com as tensões mapeadas nesse trabalho, com os demais argumentos e dimensões que compõem a controvérsia, com a questão apresentada de uma forma menos dual, quais seriam suas opiniões e atitudes? Quais seriam suas próprias tensões e limitações na compreensão do fenômeno exposto? 
É possível incorporar o questionário a ferramentas de divulgação científica virtuais, como vídeos e plataformas digitais. Outra forma interessante de aplicação dos surveys, principalmente para o desenvolvimento de ações museais, é a coleta de dados diluída em uma exposição, por exemplo. Aparatos interativos podem apresentar as principais tensões da controvérsia, situações que gerem conflitos internos aos visitantes, possibilitando uma reflexão sobre o tema e incentivando que o público tome decisões.

Os dados desse tipo de pesquisa podem revelar concepções mais consistentes sobre a percepção do público, além de propiciar que mais pessoas entrem em contato com o tema controverso, já que os surveys atingem um contingente representativo da população. Segundo Caldas (2011), a importância de conhecer o que a população pensa está intimamente ligada à definição de políticas para o incentivo de uma maior participação popular, comunicação científica e criação de ambientes de discussões com a sociedade sobre as temáticas controversas.

O questionário aplicado nesta pesquisa com visitantes no Instituto Butantan está em processo de reformulação para a incorporação de elementos que o caracterize também como ferramenta de divulgação, a partir dos subsídios elencados nesta análise. Nossa intenção é colocar o público frente a diferentes situações e compreender suas atitudes e percepções sobre esses elementos.

Uma maneira é a utilização de vídeos, entre as perguntas da pesquisa, que apresentem os diferentes tipos de argumentos dos sujeitos, colocando o público frente às contradições encontradas. Em relação às tensões de estereótipo, por exemplo, poderíamos apresentar os trechos do discurso de pesquisadores e ativistas e indagar o respondente sobre que perfil acredita ser o mais comum a cada grupo de sujeitos. Dessa forma poderemos compreender como o público projeta os participantes da questão.

Mais uma vez reiteramos a importância de expor à sociedade a dimensão sensível da controvérsia, baseada nas experiências afetivas de seus participantes. Exibir os discursos de pesquisadores que demonstram sofrer com a dor e o sofrimento animal, contribui, por exemplo, para a desconstrução dos estereótipos já mencionados. 
O principal objetivo desta investigação era apontar subsídios para a elaboração de estratégias de divulgação científica sobre a temática da experimentação animal. Para tanto, realizamos uma análise dialética, na perspectiva marxista, a fim de revelar as unidades que compõem a questão e suas relações. Nosso recorte focou em duas dimensões da controvérsia: os argumentos dos sujeitos e os aspectos contraditórios que a compõem.

Os aspectos orientadores de nossa análise basearam-se nos elementos trazidos por Lefèbvre como critérios essenciais ao método. A primeira orientação do autor é que uma análise dialética deve penetrar além da simples percepção sensível do fenômeno, apreendendo suas conexões internas e seus elementos contraditórios.

Ao penetrarmos na questão da experimentação, a partir dos discursos dos sujeitos, compreendemos que os argumentos utilizados para justificar seu trabalho são entremeados por relações de poder que tornam a questão e seus possíveis debates assimétricos. As pesquisadoras utilizam-se de muitos argumentos relacionados aos benefícios conquistados pelas ciências por meio de experimentos com animais, colocando na mesma balança o sofrimento do animal e do ser humano.

Por outro lado, esse tipo de argumento parece mascarar as relações emocionais e afetivas das pesquisadoras com os animais e o seu movimento em direção ao diálogo com os demais membros da sociedade.

Pressionados sob os grandes recursos das ciências para discursar no espaço público, os defensores do direito animal utilizam uma argumentação principalmente pautada nas características do sujeito, muitas vezes carregada de estereótipos que descaracterizam o trabalho do outro. Quando argumentaram para justificar as suas ações, o teor dessa argumentação era quase sempre voltado para o motivo, principalmente na valoração do animal como fim em si mesmo.

Outros critérios de orientação apontados por Lefèbvre como essenciais para a compreensão dos fenômenos de maneira dialética se refere à análise dos conflitos internos das contradições. A principal categoria de contradição da controvérsia da experimentação é justamente a questão do valor intrínseco atribuído ao animal. Essa categoria, dual, separa os sujeitos em dois lados opostos: os que entendem o animal como meio para minimização 
dos sofrimentos humanos e os que compreendem o animal como fim, sujeito com direito fundamental à vida. Quando interrompemos nossa análise nessa categoria de contradição, continuamos com uma visão dual da questão, é necessário, portanto, compreender as tensões que entremeiam a questão.

Para caminharmos sobre os conflitos que movimentam os sujeitos na transformação de suas realidades, analisamos o fenômeno sob a perspectiva da Teoria da Atividade, compreendendo em quais elementos são mais evidentes as tensões dentro da rede de sistemas de atividade da controvérsia.

Em nossa análise, de forma resumida, identificamos as seguintes tensões dentro do sistema de atividades (Quadro 8):

\begin{tabular}{c|c|c|c}
\hline Atividade & Pesquisa com animais & Proteção Animal & $\begin{array}{c}\text { Regulação da experimentação } \\
\text { animal }\end{array}$ \\
\hline Sujeito & Aspectos emocionais & Argumentação & Parcialidade na atividade \\
\hline Regras & - & Legislação & - \\
\hline Comunidade & - & - & - \\
\hline
\end{tabular}

Quadro 8 Contradições mais evidentes dentro dos sistemas de atividade

As contradições entre atividades de pesquisa com animais e proteção animal, podem ser resumidas no quadro abaixo (Quadro 9):

\begin{tabular}{c|c|c|c}
\hline \multirow{2}{*}{$\begin{array}{c}\text { Atividade de pesquisa } \\
\text { com animais }\end{array}$} & Sujeito & Regras & \multicolumn{2}{|c}{ Comunidade } \\
\cline { 2 - 4 } & Política & - & - \\
\hline Sujeito & - & Legislação & - \\
\hline Regras & Divulgação científica & - & - \\
\hline Comunidade & Valoração do animal & - & - \\
\hline
\end{tabular}


As contradições mais evidentes entre a atividade de proteção animal e a atividade de regulação da experimentação animal podem ser resumidas no quadro abaixo (Quadro 10)

\begin{tabular}{c|c|c|c}
\hline \multirow{2}{*}{$\begin{array}{c}\text { Atividade de regulação da } \\
\text { experimentação animal }\end{array}$} & Sujeito & Regras & Comunidade \\
\cline { 2 - 4 } & - & - & - \\
\hline Sujeito & Política & - & - \\
\hline Regras & Atuação das Ceuas & - & - \\
\hline
\end{tabular}

Quadro 10 Contradições mais evidentes entre a atividade de proteção animal e a atividade de regulação da experimentação animal

A atividade de pesquisa com animais foi considerada focal na questão da experimentação animal, enquanto os outros sistemas foram interpretados como reguladores das ações dos sujeitos, atuando principalmente sobre as regras dessa atividade. O dinamismo da rede está na superação das contradições, consideradas por Engeström, a força motriz dos sistemas de atividade.

O movimento gerado pela superação das tensões dentro e entre os sistemas, movimenta simultaneamente toda a rede, possibilitando a formação de novas atividades constituídas por novas tensões e conflitos a serem superados.

A última "regra prática" de Lefèbvre, sobre os aspectos essenciais ao método dialético materialista se refere às infinitas interações das unidades que compõem o fenômeno. Compreendemos, dessa forma, que esta pesquisa contribui por ser uma aproximação à essência do fenômeno. As propostas aqui apresentadas como estratégias de divulgação científica não pretendem construir um consenso uníssono sobre a questão, mas permitir um avanço nos conflitos e um ganho qualitativo no sistema de atividade.

É necessário ressaltar que as ações de divulgação científica podem ser atividades que geram resultados além de interagir com outras atividades. Para isso é importante reconhecer as estruturas e elementos das atividades envolvidas e os objetos que queremos transformar. 


\section{REFERÊNCIAS BIBLIOGRÁFICAS}

ALMEIDA, A. M. O contexto do visitante na experiência museal: semelhanças e diferenças entre museus de ciência e de arte. História, Ciências, Saúde. v. 12 (suplemento), p. 31-53 Manguinhos, Rio de Janeiro, 2005.

AULER, D. Interações entre ciência-tecnologia-sociedade no contexto da formação de professores da ciência. Florianópolis, 2002. Tese (Doutorado) - Centro de Educação/UFSC, Florianópolis, 2002.

BACKES, D. S; COLOMÈ, J. S; ERDMANN, R. H; LUNARDI, V. L. Grupo focal como técnica de coleta e análise de dados em pesquisas qualitativas. O Mundo da Saúde, São Paulo, v. 35, n. 4, p. 438-442, 2011.

BARBOSA, L. G. D; LIMA, M. E.E.C.C. A abordagem de temas controversos no ensino de ciências: enfoques das pesquisas brasileiras nos últimos anos. VII ENPEC, Edição Especial, 2009.

BERKOWITZ, M. \& SIMMONS, P. Integrating science education and character education: The role of peer discussion. In D. L. Zeidler (Ed.), The role of moral reasoning on socioscientific issues and discourse in science education p. 117-138. Dordrecht: Kluwer Academic Press, 2003.

BILLIG, M., C, S., EDWARDS, D., GANE, M., MIDDLETON, D; RADLEY, A. , Ideological Dilemmas: A Social Psychology of Everyday Thinking, Sage, London. 1988.

BIZERRA, A. F. Atividade de Aprendizagem em Museus de Ciências. Tese de Doutorado. Faculdade de Educação, Universidade de São Paulo, São Paulo, 2009.

BRASIL. Ministério da Saúde. Avaliação de Tecnologia em Saúde: ferramentas para gestão do SUS. Série A, normas e manuais técnicos. Brasília, DF, 2009.

BUTLER, S. Science and technology museums. Leicester: Leicester University Press, 1992.

CALDAS, G. Divulgação científica e relações de poder. Revista Informação \& Informação, Londrina, v. 15. Número especial, p. 31-42. 2010.

. Mídia e políticas públicas para a comunicação da ciência In: PORTO,

C. M; BROTAS, A. M. P; BORTOLIERO, S. T. (Org.). Diálogo entre ciência e divulgação científica: leituras contemporâneas. P. 19-36. Salvador, EDUFBA, 2011.

CAMPOS, N. F. Percepção e aprendizagem no Museu de Zoologia: uma análise das conversas dos visitantes. Dissertação (Mestrado) - Instituto de Física, Instituto de Química e Instituto de Biociências, São Paulo. 2013. 
CASTELFRANCHI, Y. Para além da tradução: o jornalismo científico crítico na teoria e na prática. In: MASSARANI, L.; POLINO, C. (Org.). Los desafios e la evaluación del periodismo científico en iberoamerica: Jornadas Iberoamericanas sobre la Ciencia en los Medios Masivos. 2008. Disponível em: Acesso em: 20 out. 2008.

COSTA, A. R. F; SOUSA, C M; MAZOCCO, F. J. Modelos de comunicação pública da ciência: agenda para um debate teórico-prático. Conexão - Comunicação e Cultura. UCSC, Caxias do Sul, v.9, n.18, p. 149-158, jul/dez. 2010

CONTIER, D; MARANDINO, M; NAVAS, A. M. Controvérsia Científica, Comunicação Pública da Ciência e Museus no Bojo do Movimento CTS. Ciência \& Ensino, vol. 1, número especial, 2007.

CROKER, R.A. An Introduction to Qualitative Research. In: CROKER, R.A.; HEIGHAM, J. (Eds.). Qualitative Research in Applied Linguistics: A Practical Introduction. London: Palgrave Macmillan, p. 3-24, 2009.

CUEVAS, A. Conocimiento científico, ciudadanía y democracia. Revista Iberoamericana de Ciencia, Tecnología y Sociedad, n. 10, v. 4, jan. 2008.

CUNHA, M. B. da. A percepção de ciência e tecnologia dos estudantes de ensino médio e a divulgação científica. Tese (Doutorado) - FE/USP, São Paulo. 2009.

D'ACAMPORA . A.J; ROSSI, L. F; ELY, J. B; VASCONCELLOS, Z. A. de.Is animal experimentation fundamental? Acta Cirúrgica Brasileira - v. 24 (5), 2009.

DANIELS, H. Abordagens atuais da teoria sociocultural e da teoria da atividade. In:

Vygotsky e a pedagogia. São Paulo: Loyola, 2003, p. 93-125.

DAVYDOV, A. A conceopt of educational activity for school children. Soviet Psycology. v. 21, n. 2, p. 50-76, 1983

DEARDEN, R. Controversial issues and the curriculum. Journal of Curriculum Studies, 13(1), 37-44, 1981.

DELICADO, A. Scientific controversies im museums: notes from a semi-peripheral country. Public Understanding of Science. v 18 (6). Pp. 759-767, 2009.

DUARTE, Newton. A anatomia do homem é a chave da anatomia do macaco: A dialética em Vigotski e em Marx e a questão do saber objetivo na educação escolar. Revista Educação \& Sociedade, Campinas:CEDES, n. 21, p.79-115, 2000a.

Duarte, N. - Vigotski e o "Aprender a Aprender": crítica às apropriações neoliberais e pósmodernas da teoria vigotskiana. Campinas: Autores Associados, 2000b. 
ENGESTRÖM, Y. The Emergence of learning activity as a historical form of human learning. In: ---. Learning by Expanding: an activity-theoretical approach to developmental research. Helsinki: Orienta-Konsultit, p. 52-77, 1987.

."Expansive learning at work: toward an activity-theoretical reconceptualization", Journal of Education and Work, Vol. 14 No. 1, pp. 133-56, 2001.

ENGESTRÖM, Y; MIETTINEN, R; PUNAMÄKI, Raija-Leena. Perspectives on Activity Theory. New York: Cambrigde University Press. 480p, 1999a.

ENGESTRÖM, Y; SANNINO, A. Discursive manifestations of contradictions in organizational change efforts: A methodological framework. Journal of Organizational Change Management Vol. 24 No. 3, pp. 368-387, 2011.

EINSEDEL, E. F; JELSOE, E; BRECK, T. Publics at the technology table: the consensus conference in Denmarck, Canada and Australia. Public Understanding of Science. v. 10, p. 83-98. 2001.

EINSIEDEL, E. F; EASTLICK, D. L. Consensus conferences as deliberative democracy: a communications perspective, Science Communication, v. 21, p. 323-43, 2000.

EUROBAROMETER. The european report on science and technology indicators. Bruxelles: Office for Official Publications of the European Communities, 2001a.

Europeans, science and technology: 12/2001, 2001b.Disponível em: <http://europa.eu.int/comm/public_opinion/ar chives/eb/ebs_154_en.pdf >. Acesso em: março 2014.

FALK, J. Free-choice science education: How we learn science outside of school. New York: Teachers College Press, 2001.

FAPESP. Percepção pública da ciência: uma revisão metodológica e resultados para São Paulo. In: Indicadores Fapesp. 2005

FENSHAM, P. School science and its problems with scientific literacy. In Levinson \& J. Thomas (Eds.), Science today: Problem or crisis? (p. 119-136). Londres: Routledge, 1997.

FERNANDES, J. L. Perspectivas sobre os discursos da divulgação da ciência. Exedra Journal, número especial, Coimbra, Portugal, 2011. Disponível em: http://www.exedrajournal.com/docs/s-CO/05-93-106.pdf. Acessado em: abril de 2014.

FILHO, A. P. Conferências de Consenso: a experiência chilena. História, Ciências, Saúde Manguinhos, Rio de Janeiro. v. 12, n. 2, p. 489-93, maio-ago. 2005. 
FREITAS, H; OLIVEIRA, M; SACCOL, A. Z; MOSCAROLA, J. O método de pesquisa survey. Revista de Administração, São Paulo, v.35, n.3, p. 105-112, jul/set. 2000.

FREITAS, D.; VILLANI, A.; ZUIN, V.G.; REIS, P.R.; OLIVEIRA, H.T. A natureza dos argumentos na análise de temas controversos: estudo de caso na formação de pós-graduandos numa abordagem CTS. Disponível em http://www.ufscar.br /ciecultura/doc/nat_argu.pdf.

GADOTTI, Moacir. "A dialética: concepção e método" in: Concepção Dialética da Educação. 7 ed. São Paulo: Cortez/Autores Associados,.Pp. 15-38, 1990

GATTI, B. A. Estudos quantitativos na educação. Educação e Pesquisa, São Paulo, v.30, n.1, p. 11-30, jan./abr. 2004

GIRAULT,Y; GRÉGOIRE M. Comment les musées et centres de sciences s'exposent aux controverses socioscientifiques, Hermès, La Revue. v3 (nº 61), p. 159-166, 2011

GOMES, M. E. S; BARBOSA, E. F. A técnica de grupos focais para obtenção de dados qualitativos. Eucativa (publicação interna), fevereiro, 1999.

GONDIN, S. M. G. Grupos focais como técnica de investigação qualitativa: desafios metodológicos. Paideia, v.12, n. 24, p. 149-161, 2003.

GOVEN, J. Deploying the consensus conference in New Zealand: democracy and deproblematization. Public Understanding of Science. v.12 p. 423-440, 2003.

GREIF, S., \& TRÉZ, T. A Verdadeira Face da Experimentação Animal. Rio de Janeiro: Sociedade Educacional “Fala Bicho", 2000.

GREGORY, J; MILLER, S. Science in public: communication, culture and credibility. New York: Plenum Trade, 1998.

HANCOCK, B.; WINDRIDGE, K.; OCKLEFORD E. An Introduction to Qualitative Research. The NIHR RDS EM / YH, 2007.

HAGELIN, J, CARLSSON, H-E; HAU, J. An overview of surveys on how people view animal experimentation: some factors that may influence the outcome. Public Understanding of Science. v. 12: 67:81, 2003.

HERZOG ,H.A; BETCHART, N. S; PITTMAN , R. B; Gender, sex role orientation, and attitudes toward animals," Anthrozoos 4: 184-191, 1991.

HUERGO, J. A. La popularización de la ciencia y la tecnología: interpelaciones desde la comunicación. In: SEMINARIO LATINOAMERICANO ESTRATEGIAS PARA LA FORMACIÓN DE POPULARIZADORES EN CIENCIA Y TECNOLOGÍA RED-POP - CONO SUR, La Plata, 14 al 17 de maio de 2001. 
KOLST, S. D. Patterns in students' argumentation confronted with rik-focused socioscientific issue. International Journal of Science Education. v. 28. n. 14, pp. 1689-1716. 2006.

KOLSTOE, S. Consensus projects: Teaching science for citizenship. International Journal of Science Education, 22, 645-664, 2000.

KOZULIN, A. O Conceito de atividade na psicologia soviética: Vygotsky, seus discípulos, seus críticos. In: DANIELS, H. Vygotsky e a pedagogia. São Paulo: Loyola, p. 111- 137, 2003.

LATOUR, B; WOOLGAR, S. A vida em laboratório: a produção dos fatos científicos. Rio de Janeiro: Relume Dumará, 1997.

LEFEBVRE, H. Lógica formal Lógica dialética. 5. ed. Rio de Janeiro: Civilização Brasileira, 1991.

LEONTIEV. A. Activity, Consciounsness and personality. New Jersey: Prentice-Hall, 186p. 1978.

LEWENTEIN, B. V.; BROSSARD, D. Models of public communication of science and technology: assessing models of public understanding. In: ELSI Outrech Materials. New York: Cornell University, 2006.

LUDKE, M; ANDRÉ, M. E. D .A. Pesquisa em educação: abordagens qualitativas. São Paulo, Editora Pedagógica e Universitária, p 99, 1986.

MACDONALD, S. Behind the scenes at Science museum. Oxford: Berg. 2002.

MACDONALD, S. Exhibitions and the public understanding of Science paradox. The Pantaneto Forum 13, 2004.

MACDONALD, S; SILVERSTONE, R. Science on display: the representation of scientific controversy in museum exhibitons. Public Understanding of Sicience. v1. pp. 69-87. 1992.

MARANDINO, M; CONTIER, D; NAVAS, A.M; BIZERRA, A; NEVES, A.L.C. Controvérsias em Museus de Ciências: reflexões e propostas para educadores. São Paulo: FEUSP, 2016, 52p.

MARCONI, M.A; LAKATOS, E.V. Fundamentos da metodologia científica. 5ạedição: São Paulo: ATLAS, 2003

Marx, K. e Engels, F. Ideologia Alemã. São Paulo, Hucitec, 1986. . Crítica ao programa de Gotha., Textos por Karl Marx e Friedrich Engels, Vol.

I. São Paulo, Ed. Sociais, 1977. . O manifesto do Partido Comunista. Ed. Brasileense, São Paulo, 1988. 
MASSON, G. Materialismo histórico e dialético: uma discussão sobre as categorias centrais. Práxis Educativa, Ponta Grossa, v. 2, n. 2, p. 105- 114, jul.-dez. 2007.

MAZDA, X. Dangerous ground? Public engagement with scientific controversy. In: CHITTENDEN, S.; FARMELO, G.; LEWENSTEIN, B. (eds). Creating connections: museums and the public understanding of research, pp. 127-44, Walnut Creek: Altamira Press, 2004.

MEADEL, C. Les controverses comme apprentissage, Hermès, La Revue, v 3 ( $n^{\circ} 73$ ), p. $45-$ 50, 2015.

MILLAR, R. Towards a Science curriculum for public understanding. In: AMOS, S; BOOHAN, R. (Ed.) Teaching Science in secondary school: a reader. RoutledgeFalmer, London, 2002

MEISNER, R.; vom LEHN, D.; HEATH, C.; BURCH, A.; GAMMON, B.; REISMAN, M. Exhibiting Performance: Co-participation in science centres and museums. International Journal of Science Education, v. 29, n. 12, 2007.

MOLINATTI, G; GIRAULT, Y. La médiation muséale des neurosciences: quatre expositions récentes sur le cerveau. Les Musées de sciences: des musées de société. Culture et Musée, v 10, pp. 97-123, 2007.

DONOVAN, J. Animal Rights and Feminist Theory. Signs 15(2):350-75., 1990.

MOURA, M. A. A construção social da cidadania científica: desafios. P. 19-30. In: MOURA, M. A. (Org.) Educação científica e cidadania: abordagens teóricas e metodológicas para a formação de pesquisadores juvenis. 280p. Belho Horizonte, UFMG/PROEX, 2012.

NARASIMHAN, M. G. Controversy in science. Journal of Biosciences. 26(3): 299-304. 2001.

NASCIMENTO, T.G; ALVETTI, M.A.S. Temas científicos contemporâneos no ensino de biologia e física. Ciência \& Ensino, vol. 1, n. 1, dezembro de 2006.

NELKIN, D. Selling science: How the press covers science and technology. New York: W. H. Freeman and Company, 1995a.

NELKIN, D. (Ed.) Controversy: politics of technical decisions. London: Sage Publications, 1992.

NEPOMUCENO, P.D.B. Método, Capitalismo e ideologia a partir de Marx. Tese de Doutorado. Instituto de Filosofia e Ciências Humanas. Unicamp, 2014

OLIVEIRA, V. L.B.; REZLER, M.A. Temas contemporâneos no ensino de Biologia do ensino médio. Revista Actascientiae. v.8. n.1. p.95 -104. jan/jun de 2006. Disponível em http://www.editoradaulbra.com.br/catalogo/periodicos/pdf/periodico1v8n1.pdf. Acesso em 18 de setembrol de 2014. 
OSBORNE, J. Science for citizenship. In M. Monk \& J. Osborne (Eds.), Good practice in science teaching p. 225-240. Buckingham: Open University Press. 2000.

PAIXÃO, R.L. Experimentação animal: razões e emoções para uma ética. Tese de Doutorado. Fundação Oswaldo Cruz, FIOCRUZ, Rio de Janeiro, 151p, 2001.

PIFER, L; SHIMIZU, K; PIFER, R. Society \& Animals 2: 95, 1994.

PIRES, M. F. de C. O materialismo histórico-dialético e a educação. Interface Comunicação, Saúde, Educação, v.1, n.1, p.83-94. 1997.

PIFER, L, KINYA S, "Public Attitudes Toward Animal Research: Some International Comparisons." Society \& Animals 2(2):95-113, 1994.

REGIS, A. H. P; CORNELLI, G. Experimentação Animal: panorama histórico e perspectivas. Revista Bioética. v.20, n.2, p.232-243. 2012.

REIS, P.G.R. O ensino das ciências através da discussão de controvérsias: realidade ou ficção? In B. D. Silva e L. S. Almeida (Eds.), Atas do VI Congresso Galaico-Português de

REIS, P. Controvérsias sócio-científicas: discutir ou não discutir? Tese de Doutorado. Faculdade de Ciências. Universidade de Lisboa, Lisboa, 2004.

Psicopedagogia (pp. 367-379). Braga: Centro de Estudos em Educação e Psicologia da Universidade do Minho, 2001.

- Controvérsias sócio-científicas: discutir ou não discutir? Tese de Doutorado. Faculdade de Ciências. Universidade de Lisboa, Lisboa, 2004.

ROLLIN, B. E. The moral status of animals and their use as experimental subjects. In: A Companion to Bioethics (H. Kuhse \& P. Singer, eds.), pp. 411-422, Oxford: Blackwell Publishers Ltd, 1998.

ROTEN. F. C. von. Mapping Perceptions of Animal Experimentation: Trend and Explanatory Factors. Social Science Quarterly. v. 89(2), 2008.

Public Perceptions of animal experimentation across Europe. Public

Understanding of Science. V. 22, n. 691. 2013. Disponível em: http://pus.sagepub.com/content/22/6/691. Acessado em novembro de 2013.

ROTH, W.-M. On the Inclusion of Emotions, Identity, and Ethico-Moral Dimensions of Actions. In: In: SANNINO, A.; DANIELS, H. e GUTIÉRREZ, K.D. (Eds.) Learning and expanding with activity theory. Cambridge: Cambridge University Press, p. 53-71, 2009. 
RUSSOW, L. M. Institutional Animal Care and Use Committees (IACUCS). In: Encyclopedia of Animal Rights and Animal Welfare (M. Bekoff \& C. A Meaney, eds.), pp. 204 - 206, Westport: Greenwood Press, 1998.

SADLER,T. D; FOWLER, S. R. A Threshold Model of Content Knowledge transfer for Socioscientific Argumentation. Wiley Interscience. 2006.

SANNINO, A. Experiencing conversations: bridging the gap between discourse and activity, Journal for the Theory of Social Behaviour, Vol. 38 No. 3, pp. 267-91. 2008.

SANTA, F. D; BARONI, V. S Raízes marxistas do pensamento de Vigotski: contribuições teóricas para a psicologia histórico cultural Kínesis, Vol. VI, n²12, Dezembro 2014, -

SANTOS, W. L. P.; MORTINER, E. Tomada de decisão para ação social responsável no ensino de ciências. Ciência \& Educação, v. 7, n. 1, p. 95-111, 2001.

SILVA, L. F. ; CARVALHO, L. M. . A Temática Ambiental e o Processo Educativo: o ensino de Física a partir de temas controversos. Ciência \& Ensino (UNICAMP), v. 1, p. V. especial, 2007. Disponível em http://www.ige.unicamp.br/ojs/index.php/cienciaeensino/ article/viewFile/152/105. Acesso em 18 de setembro de 2014

SZANTO, T. R. Value communities in science: The recombinant DNA case. In T. Brante, S. Fuller \& W. Lynch (Ed.), Controversial science. From content to contention (pp. 241-263). New York: State University of New York Press, 1993.

VYGOTSKY,L.S. Pensamento e Linguagem. São Paulo: Martins Fontes. 3ed. 135p. 1991.

. A formação social da mente. 7. Ed. São Paulo: Martins Fontes, 186p,

2007.

VOGT, C. e POLINO, C. (Orgs.). Percepção pública da ciência, Resultados da Pesquisa na Argentina, Brasil, Espanha e Uruguai. São Paulo. Editora Unicamp, 2003.

VOGT, C. et al. Percepção Pública da Ciência e Tecnologia: uma abordagem metodológica para São Paulo. In: LANDI, F. (Org.). Indicadores de Ciência, 100 Tecnologia e Inovação do Estado de São Paulo - 2004. São Paulo. Fapesp, 2005. cap. 12.

WANG, H. \& SCHMIDT, W. History, philosophy and sociology of science in science education: Results from the third international mathematics and Science study. Science and Education, 10, 51-70, 2001.

ZUIN, V.G.; FREITAS, D. A utilização de temas controversos: estudo de caso na formação inicial de licenciandos numa abordagem CTSA. Ciência \& Ensino, UNICAMP, v.1, n.2, 2007. Disponível em http://www.ige.unicamp.br/ojs/index.php/cienciaeensino/article /viewFile/136/129. Acesso em abril de 2014. 


\section{APÊNDICES}

\section{APÊNDICE A - Questionário de Percepção Pública acerca da Experimentação Animal}

\section{Sexo}

○ Feminino

- Masculino

\section{Estado Civil}

○ Solteiro

- Casado

○ Viúvo

- Outros

\section{Nível de Escolaridade}

- Ensino Fundamental Incompleto

- Ensino Fundamental Completo

- Ensino Médio Incompleto

- Ensino Médio Completo

- Ensino Superior Incompleto

- Ensino Superior Completo

- Pós-Graduação Incompleta

- Pós-Graduação Completa

\section{Faixa Etária}

○ $\quad 07-11$ anos

- $12-15$ anos

- 16- 25 anos

- 26- 35 anos

- 36-45 anos

- $46-55$ anos

- Mais de 55 anos 
Profissão

\section{Renda Familiar}

- Até um salário mínimo

- De dois a três salários mínimos

- De quatro a cinco salários mínimos

- Mais de cinco salários mínimos

Cidade

Bairro

\section{Religião}

- Catolicismo

- Protestantismo

- Espiritismo

○ Umbanda

- Candomblé

- Ateísmo

○ Não Possui

- Outro:

\section{Animais de Estimação}

○ Não possuo

- Artrópodes

○ Peixes

- Anfíbios

- Répteis 
○ Aves

- Mamíferos

\section{Hábito Alimentar}

- Vegetarianismo/Veganismo

○ Não-vegetarianismo

○ Outro:

\section{Participação e/ou contribuição à ONGs}

○ $\operatorname{Sim}$

○ Não

1. Cientistas devem usar animais em testes médicos para salvar vidas humanas.

2. Testes em laboratórios causam sofrimento, ferimentos e transtornos psicológicos nos animais.

3. Experimentos em animais conferem falsa segurança, pois os resultados obtidos em animais não são os mesmos obtidos posteriormente em humanos.

4. Os cientistas devem ser autorizados a fazer pesquisas em animais apenas para o desenvolvimento de novos medicamentos a fim de resolver problemas de saúde humana.

5. Antes de testar medicamentos em humanos, é importante testá-los em animais para evitar que voluntários humanos sejam submetidos a substâncias potencialmente perigosas.

6. Cientistas deveriam utilizar alternativas que substituam o uso de animais em testes como: aplicação de modelos matemáticos e computacionais e técnicas in-vitro com tecidos humanos e de outros animais.

7. Os testes em animais para produção de cosméticos e itens de higiene pessoal são importantes pois asseguram a integridade da saúde humana.

8. Ao comprar um produto (cosméticos e itens de higiene pessoal) é necessário verificar no rótulo se ele NÃO foi testado em animais.

9. Institutos de pesquisa devem continuar realizando testes em macacos para a produção de vacinas. 
10. Embora os testes para produção de vacinas sejam realizados em animais, é imprescindível que toda a população seja vacinada.

11. É dispensável o uso de animais para a pesquisa básica, já que não visa diretamente a solução de problemas humanos.

12. Há um alarde desnecessário sobre a experimentação animal, pois ela é regulamentada pela legislação brasileira que garante o bem-estar do animal.

13. É totalmente seguro utilizar produtos testados em animais, pois os testes são regulamentados por Lei, garantindo assim que não haja nenhum prejuízo à saúde humana.

14. Caso a eutanásia seja necessária em um experimento animal, tal procedimento deve envolver métodos que causem menos dor e sofrimento.

15. O descarte dos animais durante ou ao término dos testes é a parte dos experimentos que menos necessita de regulamentação ou métodos adequados.

16. O quanto você concorda com o uso de CADA UM desses animais em experimentos? 
APÊNDICE B - Roteiros de Entrevistas

\section{$\underline{\text { Pesquisador }}$}

Etapa 1 - Sobre a formação do pesquisador

\section{Graduação:}

Mestrado:

Doutorado:

Vínculo Institucional:

\section{Etapa 2 - Sobre a pesquisa}

1. Comente um pouco sobre sua pesquisa, a área de investigação, sua finalidade e sua importância.

2. Em que etapa da sua pesquisa você utiliza animais?

3. Que procedimentos são realizados com esses animais?

4. Quais animais são utilizados?

5. Como os animais são descartados ao fim do procedimento ou do estudo?

Etapa 3 - Sobre as impressões do pesquisador

1. Quando você pensa em animais sendo utilizados em pesquisas ou em testes farmacêuticos, o que você sente?

2. Descreva como é a sua relação com os animais utilizados em sua pesquisa. 
3. Segundo uma reportagem do G1, há uma corrente de neurocientistas que sugere que animais não humanos, incluindo todos os mamíferos, aves, além dos polvos, possuem substratos neurológicos que geram a consciência e comportamentos intencionais, ou seja, eles sentem dor. Você acredita na senciência dos animais?

4. Os procedimentos que você realiza com os animais causam algum tipo de dor ou sofrimento a eles?

5. Como você lida com essa situação?

6. Comente sobre alguma experiência (como pesquisador, ou estudante), que o uso de animais (para fins didáticos e/ou científicos) tenha te incomodado de alguma forma.

7. Você fala abertamente para as pessoas que você utiliza animais em experimentos científicos?

8. Se uma pessoa que você não conhece pergunta com o que você trabalha (no laboratório), o que você responde?

9. De que forma você lida, em seu dia a dia, com as pessoas que são radicalmente contra a experimentação animal?

\section{Etapa 4 - Sobre a Ciência e a Sociedade}

1. Você considera que a Ciência caminha para o fim dos experimentos com animais? Por quê?

2. Você utiliza, ou seria possível utilizar, algum desses métodos alternativos na sua pesquisa?

3. Há uma resistência dos pesquisadores em usar esse tipo de método? O que impede que o uso seja ampliado nos laboratórios? (comodidade, falta de infraestrutura, verba?). 
2. Você acha que esse conflito entre cientistas e membros de sociedades protetoras dos animais pode ser superado? De que forma?

4. Em sua opinião, como a ciência contribui para envolver a sociedade na discussão a respeito da experimentação animal?

5. A ciência, enquanto seus membros - cientista, pesquisadores e estudantes - possui certo receio de que a sociedade tenha voz na discussão sobre a experimentação animal. Comente sobre essa afirmação.

6. Pesquisas sobre a percepção da sociedade brasileira acerca deste tema apontam que o nível de rejeição à experimentação animal é maior entre mulheres e jovens (16 a 24 anos). Como você interpreta esses resultados?

7. Você acha que são necessárias mais ações educativas que envolvam a sociedade nessas discussões? (que a ciência deve falar mais a respeito disso com os demais membros da sociedade?).

\section{Etapa 5 - Sobre as controvérsias}

1. Há uma diferença em querer o bem-estar dos animais e repeitar o seu direito à vida. Você acha que nós, seres humanos, temos o direito de utilizar a vida dos animais em benefício antrópico, mesmo com práticas humanitárias?

2. Sabemos que pessoas que possuem pets, principalmente cães e gatos, tendem a rejeitar a experimentação animal. Em sua opinião, quais seriam as possíveis relações entre esses fatos?

3. O mesmo ocorre em relação às mulheres. Pessoas do sexo masculino tendem a aceitar mais a experimentação animal. Como você interpreta esses resultados?

4. No parágrafo $5^{\circ}$, do artigo 14, da Lei Arouca (11794/2008), consta: “Experimentos que possam causar dor ou angústia desenvolver-se-ão sob sedação, analgesia ou anestesia 
adequadas." Você concorda que provocar dor em animais deva ser permitido pela legislação?

5. A Lei Arouca é voltada para animais vertebrados. Você considera que deva ser ampliada para os demais grupos? Por quais motivos?

6. Você considera que deva haver descriminações entre os grupos animais. Cães, gatos, primatas, outros animais, devem ter legislação especial para eles, com maiores restrições?

7. Em sua opinião, o uso de animais deve ocorrer para quais fins científicos? (Caso o entrevistado não especifique, citar: cosmético, remédio, procedimentos cirúrgicos etc.)

8. As sociedades protetoras dos animais argumentam que há diversos modelos alternativos para a experimentação animal. Qual a implicação para ciência da substituição dos métodos atuais para esses métodos? 


\section{Membro SPA}

\section{Etapa 1 - Sobre a formação do entrevistado}

\section{Formação:}

\section{Vínculo Institucional:}

Função na Instituição:

Motivo de entrada na instituição:

\section{Etapa 2 - Sobre o papel das SPAs}

1. No cenário atual, qual o papel das sociedades e organizações protetoras dos animais na discussão a respeito da experimentação animal?

2. Você acha que falta divulgação ou um espaço maior na mídia às Spas?

3. Por que essa lacuna ainda é tão grande? O que falta para essas organizações ganharem um espaço maior dentro da própria sociedade?

4. Sabemos que muito do ativismo de defesa animal surgiu, em parte, devido à discussões filosóficas. Você acha que falta fundamentação teórica por parte dos ativistas? De que forma isso prejudica o trabalho das SPAs?

5. Alguns filósofos ligados à questão do direito dos animais criticam o discurso de campanha de alguns ativistas tais como: "seja contra a experimentação animal porque pode colocar sua saúde em risco". O que você acha desse tipo de discurso. É válido e eficiente?

6. Você considera esse tipo de discurso especista? 
7. Seria essa a estratégia mais eficiente para "convencer" a população sobre o direito à vida dos animais? O sofrimento e a morte dos animais por si só não seriam suficientes para as práticas serem injustas?

\section{Etapa 3 - Sobre as impressões do entrevistado - conflitos individuais}

1. Quando você pensa em animais sendo utilizados em pesquisas ou em testes farmacêuticos, o que você sente?

2. Em que momento da sua vida a questão do direito dos animais passou a ser uma preocupação real pra você? O que despertou em você a necessidade de lutar por esta causa?

3. Como você acha que o seu trabalho interfere na maneira de pensar das outras pessoas?

4. Para você, qual a importância da presença de membros de sociedades protetoras de animais nas comissões de ética no uso de animais?

5. Você faria parte de uma Ceua?

6. Comente sobre alguma experiência (como pesquisador, ou estudante), que o uso de animais (para fins didáticos e/ou científicos) tenha te incomodado de alguma forma (para biólogos, durante a graduação).

7. Sabemos que além dos testes para novas substâncias, os animais são utilizados para a produção de vacinas e soros, antiofídicos, por exemplo, na qual tanto as cobras, quanto os cavalos, participam do processo. Você acha que nessas situações o uso de animais é justificado pela necessidade?

8. Você acha incoerente que pessoas radicalmente contra à experimentação animal tomem vacinas, soros ou medicamentos que foram produzidos a partir dos experimentos com animais? 
9. De que forma você lida, em seu dia a dia, com as pessoas que são radicalmente a favor da experimentação animal?

\section{Etapa 4 - Sobre a Ciência e a Sociedade}

1. Você considera que a Ciência caminha para o fim dos experimentos com animais? Por quê?

2. Você não acha que a ciência brasileira retrocederia se parasse completamente de utilizar animais em testes?

3. Os pesquisadores afirmam que as alternativas ainda não substituem os testes em animais. Você acha que existe uma resistência dos pesquisadores brasileiros em usar métodos alternativos? O que impede que o uso seja ampliado nos laboratórios? (comodidade, falta de infraestrutura, verba?)

4. Você acha que esse conflito entre cientistas e membros de sociedades protetoras dos animais pode ser superado? De que forma?

5. Há uma diferença clara entre o bem-estar animal e o direito dos animais. Você acha que a luta pelo bem estar dos animais é suficiente para manter o "meio termo": o progresso da ciência e o uso humanitário dos animais?

6. Em sua opinião, como as SPAs contribuem para envolver a sociedade na discussão a respeito da experimentação animal?

7. A ciência, enquanto seus membros - cientista, pesquisadores e estudantes - possui certo receio de que a sociedade tenha voz na discussão sobre a experimentação animal. Comente sobre essa afirmação.

8. Pesquisas sobre a percepção da sociedade brasileira acerca deste tema apontam que o nível de rejeição à experimentação animal é consideravelmente maior entre mulheres e jovens (16 a 24 anos). Como você interpreta esses resultados? 
9. Você acha que são necessárias mais ações educativas que envolvam a sociedade nessas discussões? (que a ciência deve falar mais a respeito disso com os demais membros da sociedade?).

10. De quem seria a responsabilidade de realizar essas ações?

\section{Etapa 5 - Sobre as controvérsias - conflitos sociais}

1. Sabemos que pessoas que possuem pets, principalmente cães e gatos, bem como os vegetarianos, tendem a rejeitar a experimentação animal. Em sua opinião, quais seriam as possíveis relações entre esses fatos?

2. Você não acha que as SPAs deveriam fazer um esforço maior para destacar a importância dos direitos dos animais que não são os pets mais comuns (invertebrados, por exemplo)?

3. O principal argumento dos pesquisadores em favor ao uso de animais em testes é a garantia da segurança dos seres humanos. Você acha que os testes (fins farmacêuticos, pesquisa abásica) poderiam ser realizados em seres humanos?

4. Algumas pessoas contra experimentos em animais afirmam que os testes em humanos deveriam ser realizados em presidiários, ou pessoas que cometeram crimes hediondos. Qual a sua posição em relação a isso?

5. Você considera que deva haver descriminações entre os grupos animais? Cães, gatos, primatas, outros animais, devem ter legislação especial para eles, com maiores restrições?

6. Cientistas apontam que os testes animais beneficiam inclusive a vida dos próprios animais, com a fabricação de novos medicamentos e técnicas cirúrgicas: algumas vidas devem ser sacrificadas para que muitas outras sejam salvas. (o fim dos testes em animais prejudicaria os próprios). O que você pensa sobre isso? 


\section{Político}

\section{Etapa 1 - Sobre a atuação do entrevistado}

1. Como é o seu trabalho na frente parlamentar em defesa dos direitos animais?

2. Em que momento da sua vida a questão do direito dos animais passou a ser uma preocupação real para o senhor? O que despertou no senhor a necessidade de lutar por esta causa?

3. O senhor foi ou é membro de alguma entidade de proteção animal?

4. Como o senhor acha que o seu trabalho interfere (ou influencia) na maneira de pensar das outras pessoas?

\section{Etapa 2 - Sobre as impressões do entrevistado - conflitos individuais}

1. Quando o senhor pensa em animais sendo utilizados em pesquisas ou em testes farmacêuticos, o que o senhor sente?

2. Em sua opinião, para quais fins os testes em animais são imprescindíveis? (Caso o entrevistado não especifique, citar: cosmético, remédio, procedimentos cirúrgicos etc.)

3. De que forma o senhor lida, em seu dia a dia, com as pessoas que são radicalmente contrários ao seu ponto de vista em relação à experimentação animal?

4. Sabemos que além dos testes para novas substâncias, os animais são utilizados para a produção de vacinas e soros, antiofídicos, por exemplo, na qual tanto as cobras, quanto os cavalos, participam do processo. Você acha que nessas situações o uso de animais é justificado pela necessidade?

\section{Etapa 3 - Sobre a participação da sociedade}

1. O senhor considera que a Ciência caminha para o fim dos experimentos com animais? Por quê? 
2. O senhor acha que a ciência brasileira retrocederia se parasse completamente de utilizar animais em testes?

3. Há uma diferença clara entre o bem-estar animal e o direito dos animais. O senhor acha que a luta pelo bem estar dos animais é suficiente para manter o "meio termo": o progresso da ciência e o uso humanitário dos animais?

4. As pessoas comuns (dona de casa, o trabalhador, enfim, as pessoas que não estão relacionadas ao âmbito científico ou associadas a entidades de proteção animal) no geral não tem uma opinião formada sobre esse assunto. No cotidiano esse tema não faz parte das conversas da maioria dos brasileiros. O senhor acha que são necessárias mais ações que envolvam a sociedade nessas discussões?

5. De quem seria a responsabilidade de realizar essas ações?

6. De que maneira a frente parlamentar em defesa aos direitos dos animais envolve a sociedade em suas discussões?

7. Pesquisas sobre a percepção da sociedade brasileira acerca deste tema apontam que o nível de rejeição à experimentação animal é consideravelmente maior entre mulheres e jovens (16 a 24 anos). Como você interpreta esses resultados?

\section{Etapa 4 - Sobre as controvérsias - conflitos sociais}

1. A lei Arouca é considerada por muitos o marco regulatório da questão da experimentação animal no Brasil. Para o senhor qual o avanço essa lei promoveu nessa questão? Existem retrocessos?

2. Qual a importância da criação do Concea e obrigatoriedade das Ceua para a questão da experimentação animal?

3. O senhor considera que deva haver discriminações entre os grupos animais na legislação brasileira? Cães, gatos, primatas, outros animais, devem ter legislação especial para eles, com maiores restrições? 
4. A Lei Arouca é voltada para animais vertebrados. O senhor considera que deva ser ampliada para os demais grupos? Por quais motivos?

5. Para o senhor, esse conflito entre cientistas e membros de sociedades protetoras dos animais pode ser superado? De que forma?

6. O senhor acha que a Lei Arouca de alguma forma legitima o uso de animais em pesquisa?

7. Para o senhor, quais são as principais barreiras que impedem ou dificultam a ciência brasileira a adotar de maneira sistematizada e eficiente os métodos substitutivos à experimentação animal?

8. As sociedades de proteção animal afirmam que o decreto 6.899 que regulamenta a Lei Arouca, sobrepõe a lei no que diz respeito aos métodos alternativos, considerando os 3R's como tal método. O que o senhor tem a dizer sobre isso?

9. Deputado, o senhor está satisfeito com o PL 6602/2013?

10. Quais foram os motivos para a alteração do parágrafo oitavo?

11. Que avanços a aplicação da do PL como está trará para a questão da experimentação animal? 


\section{Representante do Concea}

\section{Etapa 1 - Sobre a formação}

\section{Formação:}

\section{Vínculo Institucional:}

\section{Função na Concea:}

\section{Etapa 2 - Sobre o papel do Concea na questão}

1. Qual a missão do Conselho?

2. Qual a importância da obrigatoriedade das CEUAs nos institutos de pesquisa brasileiros, estabeçecida pelo Concea?

3. Qual a importância da presença de um membro de sociedade protetora dos animais no Concea?

\section{Etapa 3 - Sobre o trabalho no Concea}

1. Comente um pouco sobre a rotina de trabalho no Conselho?

2. Qual o seu papel nesse trabalho?

3. Todos os integrantes se envolvem igualmente no "julgamento" das propostas?

4. Qual a importância do "Princípio dos 3 R's" no trabalho da Concea?

5. Qual é a composição do Concea? Todos os membros possuem a mesma voz?

\section{Etapa 4 - Sobre as impressões do entrevistado - conflitos individuais}

1. Quando você pensa em animais sendo utilizados em pesquisas ou em testes farmacêuticos, o que você sente?

2. Você acredita na senciência dos animais? 
3. Os procedimentos com animais que esta CEUA aprova causam algum tipo de dor ou sofrimento a eles?

4. Como você lida com essa situação?

5. Comente sobre alguma experiência (como pesquisador, ou estudante), que o uso de animais (para fins didáticos e/ou científicos) tenha te incomodado de alguma forma.

6. De que forma você lida, em seu dia a dia, com as pessoas que são radicalmente contra a experimentação animal?

\section{Etapa 5 - Sobre a Ciência e a Sociedade}

1. Você considera que a Ciência caminha para o fim dos experimentos com animais? Por quê?

2. Você acredita que exista uma certa resistência dos pesquisadores em usar esse métodos alternativos? O que impede que o uso seja ampliado nos laboratórios? (comodidade, falta de infraestrutura, verba?)

3. Você acha que esse conflito entre cientistas e membros de sociedades protetoras dos animais pode ser superado? De que forma?

4. Em sua opinião, como a ciência contribui para envolver a sociedade na discussão a respeito da experimentação animal?

5. A ciência, enquanto seus membros - cientista, pesquisadores e estudantes - possui certo receio de que a sociedade tenha voz na discussão sobre a experimentação animal. Comente sobre essa afirmação.

6. Pesquisas sobre a percepção da sociedade brasileira acerca deste tema apontam que o nível de rejeição à experimentação animal é maior entre mulheres e jovens (16 a 24 anos). Como você interpreta esses resultados? 
7. Você acha que são necessárias mais ações educativas que envolvam a sociedade nessas discussões? (que a ciência deve falar mais a respeito disso com os demais membros da sociedade?).

\section{Etapa 6 - Sobre as controvérsias - conflitos sociais}

1. Sabemos que pessoas que possuem pets, principalmente cães e gatos, tendem a rejeitar a experimentação animal. Em sua opinião, quais seriam as possíveis relações entre esses fatos?

2. O mesmo ocorre em relação às mulheres. Pessoas do sexo masculino tendem a aceitar mais a experimentação animal. Como você interpreta esses resultados?

3. Você acha que a legislação atual é suficiente para a regulamentação dos experimentos com animais no Brasil?

4. No parágrafo $5^{\circ}$, do artigo 14 , da Lei Arouca (11794/2008), consta: "Experimentos que possam causar dor ou angústia desenvolver-se-ão sob sedação, analgesia ou anestesia adequadas." Você concorda que provocar dor em animais deva ser permitido pela legislação?

5. A Lei Arouca é voltada para animais vertebrados. Você considera que deva ser ampliada para os demais grupos? Por quais motivos?

6. Você considera que deva haver descriminações entre os grupos animais. Cães, gatos, primatas, outros animais, devem ter legislação especial para eles, com maiores restrições?

7. Em sua opinião, o uso de animais deve ocorrer para quais fins científicos? (Caso o entrevistado não especifique, citar: cosmético, remédio, procedimentos cirúrgicos etc.)

8. As sociedades protetoras dos animais argumentam que há diversos modelos alternativos para a experimentação animal. O que você pensa sobre isso 
